\begin{tabular}{|l|l|}
\hline $\begin{array}{l}\text { 2. To: (Receiving Organization) } \\
\text { Distribution }\end{array}$ & $\begin{array}{l}\text { 3. From: (Originating Organization) } \\
\text { DA Burbank/TM Hohl/MJ Klem }\end{array}$ \\
\hline 5. Proj./Prog./Dept./Div.: & $\begin{array}{l}\text { 6. Design Authority/Design Agent/Cog. } \\
\text { Engr.: } \\
\text { W-465, W-520 }\end{array}$ \\
\hline
\end{tabular}

8. Originator Remarks:

For approval and release

11. Receiver Remarks: 11A. Design Baseline Document? [] Yes [X] No

4. Related EDT No:

NA

7. Purchase Order No.:

NA

9. Equip./Component No.:

NA

10. System/Bldg.Facility:

NA

12. Major Assm. Dwg. No.:

NA

13. Permit/Permit Application No.:

$\mathrm{NA}$

14. Required Response Date:

--

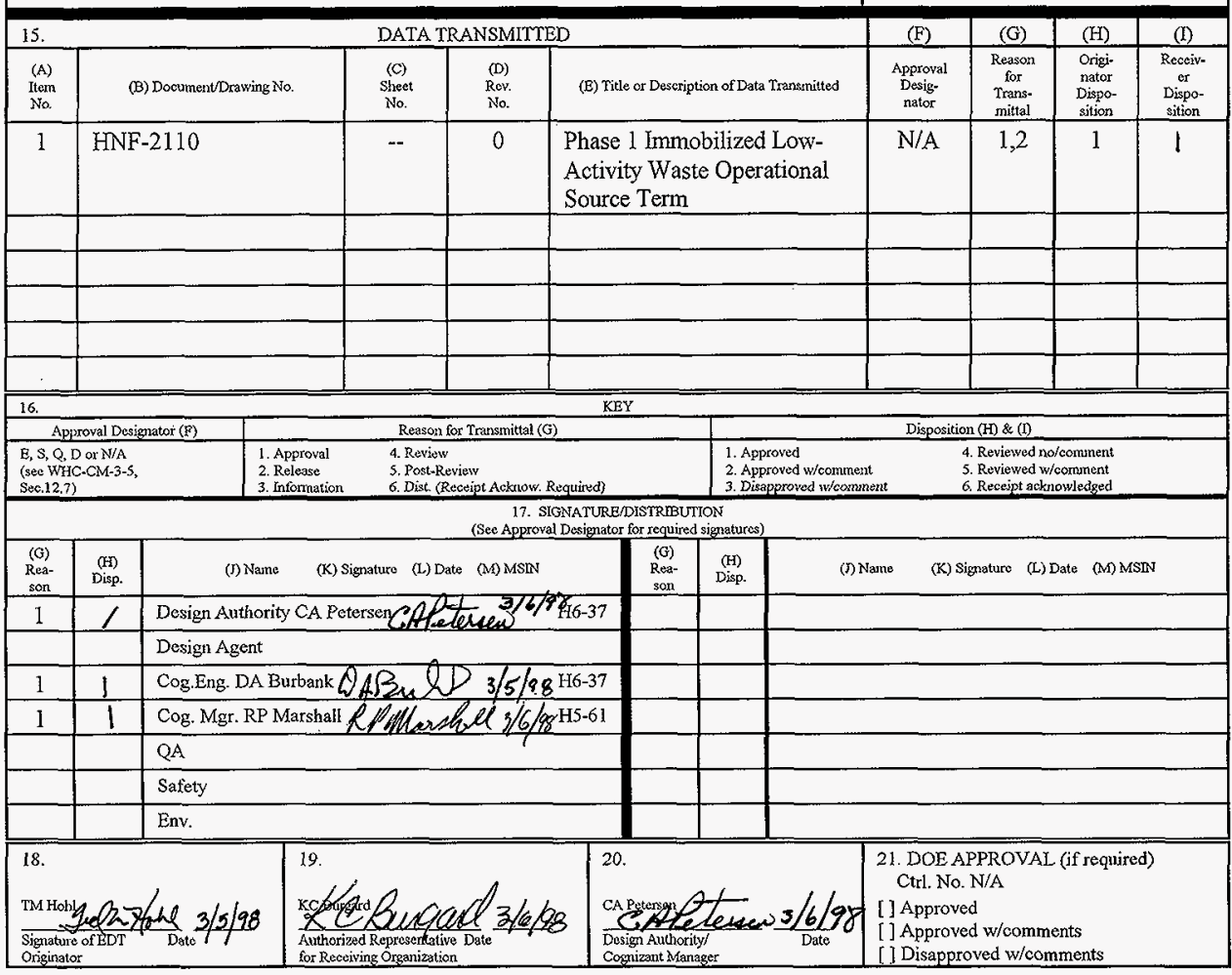


HNF-2110, Rev. 0

\title{
Phase 1 Immobilized Low-Activity Waste Operational Source Term
}

\author{
D. A. Burbank, T. M. Hohl, M. J. Klem \\ SGN Eurisys Services Corporation, Richland, WA 99352 \\ U.S. Department of Energy Contract DE-AC06-96RL13200 \\ EDT/ECN: 623802 \\ UC: 721 \\ Org Code: $S 1400$ \\ Charge Code: D4DKM \\ B\&R Code: EW3130010 Total Pages: 107
}

Key Words: Low-activity waste, ILAW, Source term, TWRS, Contact-handled, Remotehandled, Phase 1 , Privatization

Abstract: This report presents an engineering analysis of the Phase 1 privatization feeds to establish an operational source term for storage and disposal of immobilized lowactivity waste packages at the Hanford Site. The source term information is needed to establish a preliminary estimate of the numbers of remote-handled and contact-handled waste packages. A discussion of the uncertainties and their impact on the source term and waste package distribution is also presented. It should be noted that this study is concerned with operational impacts only. Source terms used for accident scenarios would differ due to alpha and beta radiation which were not significant in this study.

TRADEMARK DISCLAIMER. Reference herein to any specific commercial product, process, or service by trade name, trademark, manufacturer, or otherwise, does not necessarily constitute or imply its endorsement, recommendation, or favoring by the United States Government or any agency thereof or its contractors or subcontractors.

Printed in the United States of America. To obtain copies of this document, contact: Document Control

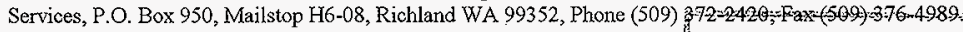

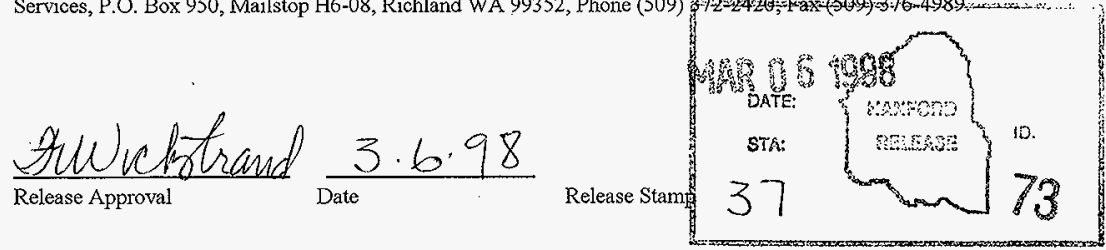

\section{Approved for Public Release}




\section{PHASE 1 IMMOBILIZED LOW-ACTIVITY WASTE OPERATIONAL SOURCE TERM}

March 1998

D. A. Burbank

T. M. Hohl

M. J. Klem

SGN Eurisys Services Corporation

Richland, Washington

Prepared for:

Lockheed Martin Hanford Corporation

Richland, Washington 
HNF-2110 Rev 0

This page intentionally left blank. 


\section{HNF-2110 Rev 0}

\section{EXECUTIVE SUMMARY}

This report presents an engineering analysis of the Tank Waste Remediation System Phase 1 privatization feeds to establish an operational source term for storage and disposal of immobilized low-activity waste packages at the Hanford Site. The source term information is needed to establish a preliminary estimate of the number of remote-handled and contact-handled waste packages. The report also presents the uncertainties and their impact on the source term and waste package distribution. It should be noted that this study covers operational impacts only. Source terms used for accident scenarios would differ because of alpha and beta radiation, which were not significant in this study.

The key conclusions of this study are that the radiation dose rate is a strong function of package wall thickness and cesium removal efficiency, that cesium removal alone will not make all the immobilized low-activity waste packages contact handled, and the waste packages from Envelope $B$ will have a significantly higher dose rate than those from Envelopes $A$ and $C$.

This study uncovered a high probability that a significant quantity of both remotehandled and contact-handled waste will be produced. A cost savings should be realized as less expensive disposal and transportation systems could be used for handling the contact-handled immobilized low-activity waste. A follow-up study should be performed when additional information from the two vendors and the revised Tank Waste Remediation System Operation and Utilization Plan are available. 
HNF-2110 Rev 0

This page intentionally left blank. 
HNF-2110 Rev 0

\section{CONTENTS}

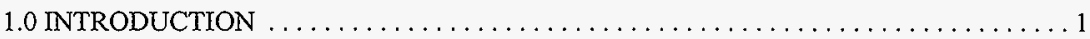

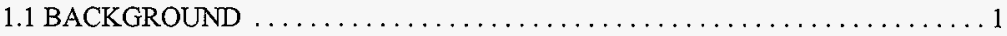

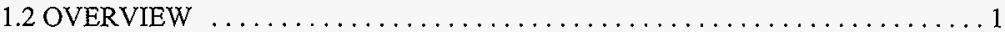

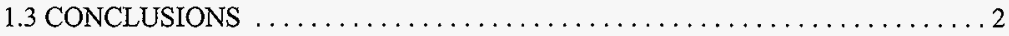

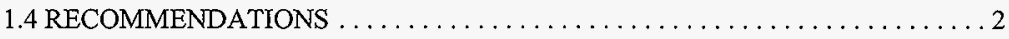

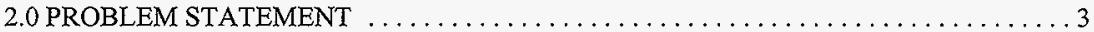

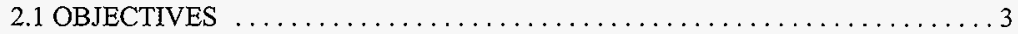

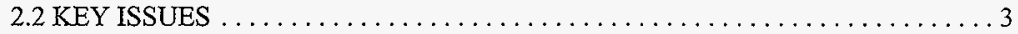

2.2.1 Solubility of Key Radionuclides . . . . . . . . . . . . . . . . . 3

2.2 .2 Waste Package Type . . . . . . . . . . . . . . . . . . . . . . . 4

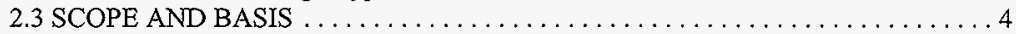

2.3.1 Phase 1 Waste Retrieval Sequence and Feed Composition $\ldots \ldots \ldots \ldots .4$

2.3.2 Phase 1 Waste Significant Radionuclides ...................5

2.3.3 Phase 1 Decay Date for Source Term ..................... 5

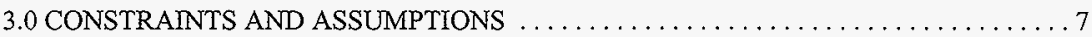

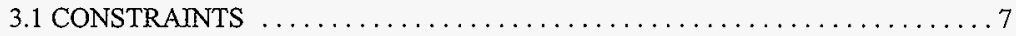

3.1.1 Privatization Specification Number $2 \ldots \ldots \ldots \ldots \ldots \ldots \ldots \ldots \ldots \ldots \ldots \ldots \ldots \ldots$

3.1.2 Interface Control Document ........................ 7

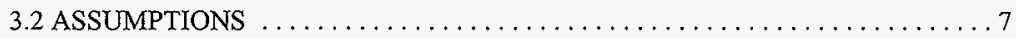

3.2.1 TWRS Operation and Utilization Plan $\ldots \ldots \ldots \ldots \ldots \ldots \ldots \ldots \ldots$

3.2.2 Solubility of Waste Feed Constituents . . . . . . . . . . . . . . . . 7

3.2.3 Radionuclide Source Term . . . . . . . . . . . . . . . . . . . 10

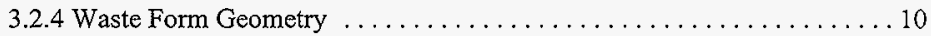

3.2 .5 Waste Package Size ............................... 11

3.2.6 Waste Container Wall Thickness $\ldots \ldots \ldots \ldots \ldots \ldots \ldots \ldots \ldots \ldots \ldots \ldots \ldots$

3.2.7 Contribution to Dose Rate from Neutron Emission ............. 12

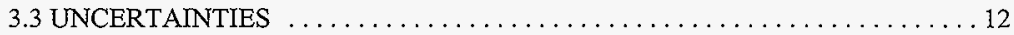

3.3.1 Cesium Separations Efficiency ........................ 12

3.3.2 Waste Form Geometry ............................. 12

3.3.3 Waste Package Size ............................ 12

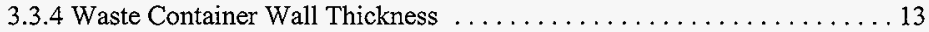

3.3.5 Waste Package Dose Rate Distribution $\ldots \ldots \ldots \ldots \ldots \ldots \ldots \ldots . \ldots \ldots$

4.0 SOURCE TERM AND DOSE RATE ANALYSIS $\ldots \ldots \ldots \ldots \ldots \ldots \ldots \ldots \ldots \ldots \ldots \ldots \ldots$

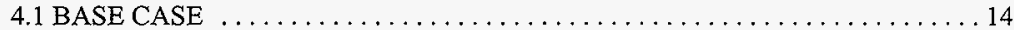

4.1.1 Base-Case Radionuclide Source Term $\ldots \ldots \ldots \ldots \ldots \ldots \ldots \ldots \ldots \ldots$

4.1.2 Base-Case Dose Rate Distribution ...................... 14

4.1.3 Base-Case Remote-Handled and Contact-Handled Package Counts . . . . 14

4.2 EFFECT OF WASTE CONTAINER WALL THICKNESS . . . . . . . . . . 14 
HNF-2110 Rev 0

4.2.1 Dose Rate Distribution . . . . . . . . . . . . . . . . . . 16

4.2.2 Remote-Handled and Contact-Handled Package Counts . . . . . . . . 16

4.3 EFFECT OF CESIUM SEPARATION EFFICIENCY . . . . . . . . . . . . 16

4.3.1 Radionuclide Source Term . . . . . . . . . . . . . . . . . . 16

4.3.2 Dose Rate Distribution .......................... 16

4.3.3 Remote-Handled and Contact-Handled Package Counts ........... 16

4.4 EFFECT OF DECAYING WASTE TO FEED DELIVERY DATE BY BATCH . . 18

4.4.1 Radionuclide Source Term $\ldots \ldots \ldots \ldots \ldots \ldots \ldots \ldots \ldots \ldots, 18$

4.4.2 Dose Rate Distribution ........................... 19

4.4.3 Remote-Handled and Contact-Handled Package Counts . . . . . . . . . 19

4.5 EFFECT OF CHANGES IN WASTE LOADING $\ldots \ldots \ldots \ldots \ldots \ldots \ldots \ldots$

4.5.1 Radionuclide Source Term . . . . . . . . . . . . . . . . . . 19

4.5.2 Dose Rate Distribution ......................... 20

4.5.3 Remote-Handled and Contact-Handled Package Counts . . . . . . . 20

4.6 EFFECT OF WASTE FORM GEOMETRY $\ldots \ldots \ldots \ldots \ldots \ldots \ldots \ldots \ldots 22$

4.6.1 Radionuclide Source Term . . . . . . . . . . . . . . . . . 22

4.6.2 Dose Rate Distribution ........................... 22

4.6.3 Remote-Handled and Contact-Handled Package Counts ..........22

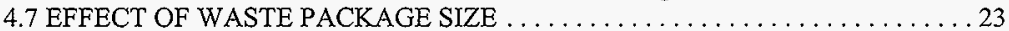

4.7.1 Dose Rate Distribution .......................... 23

4.7.2 Remote-Handled and Contact-Handled Package Counts .......... 24

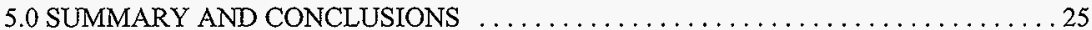

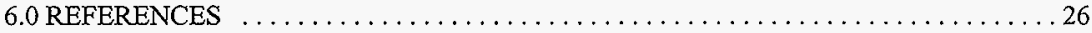

APPENDIX A

Radionuclide Source Terms for Base and Sensitivity Cases $\ldots \ldots \ldots \ldots \ldots \ldots$ A-1

APPENDIX B

ILAW Shielding Evaluation $\ldots \ldots \ldots \ldots \ldots \ldots \ldots \ldots \ldots \ldots \ldots \ldots \ldots, 1$ 
HNF-2110 Rev 0

\section{LIST OF FIGURES}

4-1. Contact-Handled ILAW Packages vs. Package Wall Thickness for the Base Case. . . . 17

4-2. Contact-Handled ILAW Packages Relative to Cesium Removal Efficiency. . . . . . . . 17

4-3. Effect of Decaying ILAW Source Term to Feed Delivery Date on CH Packages. . . . . 21

4-4. Effect of Waste Loadings on Contact-Handled Package Count. .............. 21

\section{LIST OF TABLES}

2-1. Significant Isotopes for ILAW Operational Source Term. $\ldots \ldots \ldots \ldots \ldots \ldots \ldots 6$

3-1. Specific Product Requirements of Concern for ILAW Operational Source Term. . . . . 8

3-2. Assumptions Made for Base Case Scenario. ...................... 9

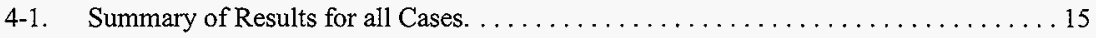

4-2. Remote- and Contact-Handled Package Counts for Cesium Separation Efficiency Sensitivity Cases. . . . . . . . . . . . . . . . . . . . . . . . 18

4-3. Remote- and Contact-Handled Package Counts for Waste Loading Sensitivity Cases. . . . . . . . . . . . . . . . . . . . . . . . . 22 
HNF-2110 Rev 0

\section{ACRONYMS AND ABBREVIATIONS}

$\begin{array}{ll}\text { BBI } & \text { Best-Basis Inventory } \\ \text { CH } & \text { Contact-Handled } \\ \text { DF } & \text { Decontamination Factor } \\ \text { DOE } & \text { Department of Energy } \\ \text { DST } & \text { Double-Shell Tank } \\ \text { ILAW } & \text { Immobilized Low-Activity Waste } \\ \text { RH } & \text { Remote-Handled } \\ \text { TWRS } & \text { Tank Waste Remediation System } \\ \text { TWRSO\&UP Tank Waste Remediation System Operation and Utilization Plan }\end{array}$


HNF-2110 Rev 0

\section{PHASE 1 IMMOBILIZED LOW ACTIVITY WASTE OPERATIONAL SOURCE TERM}

\subsection{INTRODUCTION}

This report presents an engineering analysis of the Tank Waste Remediation System (TWRS) Phase 1 privatization feeds to establish an operational source term for storage and disposal of immobilized low-activity waste (ILAW) packages at the Hanford Site. The source term information is needed to establish a preliminary estimate of the numbers of remote-handled and contact-handled waste packages. The report also presents the uncertainties and their impact on the source term and waste package distribution. It should be noted that this study covers operational impacts only. Source terms used for accident scenarios would differ because of alpha and beta radiation, which were not significant in this study.

\subsection{BACKGROUND}

The interface control document for the ILAW waste product (ICD-15) (Berry 1997) and the alternatives generation analysis report for ILAW disposal (Burbank and Klem 1997) identifies the technical issues and impacts on ILAW package dose rates and establishing the preliminary estimate on quantity of remote- and contact-handled waste packages. The alternative concepts for the ILAW disposal system layouts assume that waste packages will be stacked six high, and contain a single waste type with one of four possible combinations of waste characteristics. The characteristic combinations are remote- or contact-handled mixed waste and remote- or contact-handled non-mixed waste. The different waste characteristics have different shielding and disposal system design requirements. The likelihood that remote handling equipment and shielded facilities may not be required for a significant fraction of the ILAW packages provides an opportunity for substantial cost savings over the life of the disposal program.

\subsection{OVERVIEW}

The mission of the TWRS ILAW disposal project is to receive, transport, store, and dispose of treated low-activity tank waste in a safe and environmentally sound manner. The ILAW disposal program schedule shows disposal capacity to be required beginning in 2005 when the ILAW storage vaults are filled to capacity. The most recent estimate of ILAW production for the maximum order quantity in Phase 1 (ending in 2011) is 11,370 packages based on retrieval and treatment of waste from 11 double-shell tanks (DST) as specified in the Tank Waste Remediation System Operation and Utilization Plan (Kirkbride et al. 1997). The previous estimate was 13,200 based the TWRS Process Technical Baseline (Orme 1996). 
HNF-2110 Rev 0

The Phase 2 ILAW source term and projected mixture of the estimated 85,000 packages as remote-handled and contact-handled waste will be evaluated at a future date.

\subsection{CONCLUSIONS}

- The radiation dose rate is a strong function of package wall thickness and cesium removal efficiency.

- Cesium removal alone will not make all the ILAW packages contact handled.

- ILAW waste packages from Envelope B have a significantly higher dose rate than those from Envelopes $\mathrm{A}$ and $\mathrm{C}$.

- Glass marbles provide less self-shielding than monoliths and therefore produce a higher dose rate.

- Waste package size has a negligible effect on the dose rate.

- At least 50 percent of the ILAW packages will be contact handled.

- At least 25 percent of the ILAW packages will be remote handled unless additional removal of radionuclides is undertaken.

\subsection{RECOMMENDATIONS}

- A follow-up study should be performed when additional information from the two vendors and the revised Tank Waste Remediation System Operation and Utilization Plan (TWRSO\&UP) are available.

- The key radionuclides identified in this study should be included in the process modeling portions of the revised TWRSO\&UP.

- $\quad$ Because shielded vaults are the only type available at the beginning of Phase $1 B$ processing, it is recommended that the higher dose rate packages, i.e., Envelope B, be processed first. 
HNF-2110 Rev 0

\subsection{PROBLEM STATEMENT}

This section describes the problem statement, the objectives, the scope and basis, and key issues identified during the analysis.

\subsection{OBJECTIVES}

The problem statement for this analysis is: What is the projected number of contacthandled and remote-handled ILAW packages for Phase 1 storage and disposal?

The objectives of this evaluation are as follows:

- Evaluate the inventory of radionuclides in the 11 DSTs for Phase 1 privatization based on information in the Tank Waste Remediation System Operation and Utilization Plan (Kirkbride et al. 1997) and the best-basis inventory (BBI) (Jones et al. 1997a, 1997b, 1997c, 1997d, and 1997e, Place 1997a, and 1997b, Shelton 1997, Shelton et al. 1997a, 1997b and 1997c). The BBI values used are the values published in August 1997, reflecting the Revision F version of the best-basis values, which are based on data published in tank characterization reports.

- Determine an operational source term for the Phase 1 ILAW feed.

- Determine the distribution of remote-handled and contact-handled ILAW for the 11,370 waste packages.

\subsection{KEY ISSUES}

This section describes the key issues that have been identified during the course of this analysis.

\subsubsection{Solubility of Key Radionuclides}

The feed staging and radionuclide solubility data from the TWRSO\&UP and total inventory of other radionuclides from the BBI are used to establish source terms for the ILAW packages. The data from the TWRSO\&UP is reported as solid and liquid fractions while the data from the $\mathrm{BBI}$ is reported as a complete tank inventory. Solubilities of the radionuclides from the BBI data are not available at this time. These radionuclides are assumed to be completely soluble and follow the sodium into the ILAW for this study. The few exceptions to this assumption which explained in Section 3.2.2.

The assumption that the $\mathrm{BBI}$ radionuclides are completely soluble is conservative and has an impact on the source terms generated in this study. The fiscal year (FY) 1998 revision of the TWRSO\&UP is expected to contain more extensive information on radionuclide inventory and 
HNE-2110 Rev 0

solubility. After the revised TWRSO\&UP document is available, this study should be revisited to determine the effect of any new feed staging and radionuclide solubility data.

\subsubsection{Waste Package Type}

The TWRS Privatization Specification 2 (DOE-RL 1996) requires that the ILAW products be in a sealed metal container that encloses the waste form and is leak tight. The closure system must remain intact for a storage period of 50 years in an ambient-temperature, ventilated enclosure. The container material must be resistant to degradation by microbial action, moisture, radiation effects, or chemical reactions with the container contents under the expected storage, handling, and disposal operations. The integrity of the container must not be jeopardized by wind, blowing sand, precipitation, sunlight, or extreme temperatures.

The above package criteria do not limit the waste container to a single metal barrier or single wall thickness. The containment could consist of multiple small packages placed inside the designated size of waste package. Detailed information on the type of waste package and containment is not available at this time.

\subsection{SCOPE AND BASIS}

The technical basis of this analysis is derived from the Tank Waste Remediation System Operation and Utilization Plan (Kirkbride et al. 1997) and best-basis inventory (Jones et al. 1997a, 1997b, 1997c, 1997d, and 1997e, Place 1997a, and 1997b, Shelton 1997, Shelton et al. 1997a, 1997b and 1997c). These source documents are described in more detail in the following subsections.

\subsubsection{Phase 1 Waste Retrieval Sequence and Feed Composition}

The Tank Waste Remediation System Operation and Utilization Plan (Kirkbride et al. 1997) establishes the operating scenario and plans for delivering the waste feed to two private contractors and overall process flowsheets for Phase 1 and Phase 2 of privatization effort. The document is to be updated regularly with the most recent inventory and sludge washing data.

Waste from 11 DSTs will be retrieved and transferred to feed staging tanks 241-AP-102 and 241-AP-104 and quantified before transfer to the private contractors' feed tanks (241-AP-106 and 241-AP-108). A total of 22 feed batches will be prepared and transferred to the private contractors.

Three feed envelopes (Envelope A, B and C) are established by the Privatization Specification 7 (DOE-RL 1996). Each envelope provides a different technical challenge for the private contractors. 
HNF-2110 Rev 0

\subsubsection{Phase 1 Waste Significant Radionuclides}

The BBI provides the inventory and estimates of chemical and radionuclide constituents for the 11 Phase 1 DSTs. From the BBI data, a selection of radionuclides that contributed a significant portion of the dose was selected. To be selected, a radionuclide must be a gamma emitter (or have a daughter that is) and contribute greater than 0.1 percent of the total dose. This selection was deemed as conservative for estimating the Phase 1 dose rate.

Table 2-1 lists the isotopes that were found to contribute greater than 0.1 percent of the dose rate for Phase 1 privatization. In addition to the following radionuclides, ${ }^{134} \mathrm{Cs}$ was identified by Savino (1998). It was not included because it will decay to a dose contribution level of less than 0.1 percent before the waste is delivered to the private contractors. See Appendix A for total dose rates. The details of the selection of the significant "key" radionuclides are presented in Appendix B.

\subsubsection{Phase 1 Decay Date for Source Term}

The radionuclides contained in the $\mathrm{BBI}$ are decayed to a uniform date of January 1, 1994. The radionuclide data in the TWRSO\&UP also were decayed to a uniform date of January 1,1994 , to match the decay date of the BBI. For the base case in this study, the radionuclide data from the TWRSO\&UP and BBI were decayed to July 1, 2002, for Envelopes $\mathrm{A}, \mathrm{B}$, and $\mathrm{C}$. This date was chosen because it represents the approximate date that the private contractors will begin to process feed.

The decay dates and, therefore, the inventories of the radionuclides could have been adjusted to accommodate for the specific delivery date for each batch. However, a change in the schedule or processing order could limit the usability of this source term. By using the fixed date of July 1,2002 , this source term will retain its utility if schedule or processing changes occur, and offer a minor degree of conservatism as well. Section 4.4 presents a sensitivity case that studied the effects of decaying the radionuclides to the feed delivery date for each batch. 
HNF-2110 Rev 0

Table 2-1. Significant Isotopes for ILAW Operational Source Term.

\begin{tabular}{||c|c|c|c||}
\hline Isotope & $\begin{array}{c}\text { Half Life } \\
(\mathrm{yr})\end{array}$ & $\begin{array}{c}\text { Specific } \\
\text { Activity }^{2} \\
\text { (Ci/g) }\end{array}$ & $\begin{array}{c}\text { Unit Dose Rate }^{3} \\
\left(\frac{m R e m \cdot m^{3}}{h r \cdot C i}\right)\end{array}$ \\
\hline${ }^{60} \mathrm{Co}$ & 5.271 & $1.13 \mathrm{E}+03$ & $6.70 \mathrm{E}+02$ \\
\hline${ }^{90} \mathrm{Sr}$ & 28.78 & $1.38 \mathrm{E}+02$ & $7.53 \mathrm{E}-01$ \\
\hline${ }^{106} \mathrm{Ru}$ & 1.020 & $3.31 \mathrm{E}+03$ & $4.12 \mathrm{E}+01$ \\
\hline${ }^{125} \mathrm{Sb}$ & 2.758 & $1.04 \mathrm{E}+03$ & $6.82 \mathrm{E}+01$ \\
\hline${ }^{126} \mathrm{Sn}$ & $2.5 \mathrm{E}+5$ & $1.14 \mathrm{E}-02$ & $3.03 \mathrm{E}+02$ \\
\hline${ }^{137} \mathrm{Cs}$ & 30.07 & $8.68 \mathrm{E}+01$ & $1.10 \mathrm{E}+02$ \\
\hline${ }^{152} \mathrm{Eu}$ & 13.54 & $1.74 \mathrm{E}+02$ & $2.54 \mathrm{E}+02$ \\
\hline${ }^{154} \mathrm{Eu}$ & 8.593 & $2.70 \mathrm{E}+02$ & $2.89 \mathrm{E}+02$ \\
\hline
\end{tabular}

Note: ${ }^{1}$ Source of information is Parrington (1996).

${ }^{2}$ Does not include activity of daughter products.

${ }^{3}$ Source of information is Savino (1998), based on $1.27 \mathrm{~cm}(0.5 \mathrm{in}$.) steel shielding (package/box), marble waste form, standard waste package size and includes doses from daughter decay products. 
HNF-2110 Rev 0

\subsection{CONSTRAINTS AND ASSUMPTIONS}

This section describes the constraints and assumptions that define the framework of this analysis.

\subsection{CONSTRAINTS}

Constraints are requirements imposed on the system by outside agencies and are beyond control of design, construction and operating organizations.

\subsubsection{Privatization Specification Number 2}

The Product Requirements Section of the Privatization Specification 2 (DOE-RL 1996) controls the physical and radiological characteristics of the ILAW packages. The specific product requirements of concern to this study are listed in Table 3-1 with a description of the constraints the requirement imposes.

\subsubsection{Interface Control Document}

This engineering study is driven by Issue 15T, "Package Dose Rate Issue," in the interface control document (Berry 1997). This issue questions the rationale for establishing the current design basis of 100 percent remote-handled packages. The issue also directs that if the current design basis cannot be justified, a source term must be developed to determine the expected dose rates of the Phase I ILAW packages and from this the amount of contact- and remote-handled waste. This engineering study will provide some resolution of this issue.

\subsection{ASSUMPTIONS}

Assumptions are made for areas where limited information is available and the required analysis has not been completed. The main assumptions used in this analysis and the rational behind them are described in Table 3-2.

\subsubsection{TWRS Operation and Utilization Plan}

The source of the Phase 1 ILAW source term data is Tank Waste Remediation System Operation and Utilization Plan (Kirkbride et al. 1997). Therefore, all assumptions in Kirkbride et al. (1997) are implied here as well.

\subsubsection{Solubility of Waste Feed Constituents}

The key isotopes are ${ }^{60} \mathrm{Co},{ }^{90} \mathrm{Sr},{ }^{106} \mathrm{Ru},{ }^{125} \mathrm{Sb},{ }^{126} \mathrm{Sn},{ }^{137} \mathrm{Cs}$, ${ }^{152} \mathrm{Eu}$, and ${ }^{154} \mathrm{Eu}$. The inventories of soluble ${ }^{90} \mathrm{Sr}$ and ${ }^{137} \mathrm{Cs}$ will be obtained from the TWRSO\&UP. The inventories of the other six key isotopes will be obtained from the BBI. The solubilities of ${ }^{90} \mathrm{Sr}$ and ${ }^{137} \mathrm{Cs}$ are based on 


\section{HNF-2110 Rev 0}

Table 3-1. Specific Product Requirements of Concern for ILAW Operational Source Term.

\begin{tabular}{|c|c|}
\hline Product Requirement & Description of Requirement \\
\hline Package Description & $\begin{array}{l}\text { The immobilized low-activity waste (ILAW) products shall be in the form of a } \\
\text { package. The constituent parts of each package are: a sealed metal container } \\
\text { enclosing a waste form, in which the ILAW product is emplaced; and optional matrix } \\
\text { material, which may be used to encapsulate the waste form; and an optional filler } \\
\text { material, which may be used to fill void spaces in the container before it is closed. }\end{array}$ \\
\hline Waste Loading & $\begin{array}{l}\text { For every gram-mole of sodium provided to the Contractor in Waste Envelopes A and } \\
\text { C, the Contractor may produce up to } 100 \mathrm{~cm}^{3} \text { of ILAW product (based on the external } \\
\text { dimensions of the package). For every gram-mole of sodium in Waste Envelope B, } \\
\text { the Contractor may produce up to } 250 \mathrm{~cm}^{3} \text { of ILAW product (based on the external } \\
\text { dimensions of the package). }\end{array}$ \\
\hline Size and Configuration & $\begin{array}{l}\text { The package shall be a rectangular metal container and shall have an external } \\
\text { dimension, including all appurtenances, of } 1.8 \mathrm{~m} \text { (length) } \times 1.2 \mathrm{~m} \text { (width) } \times 1.2 \mathrm{~m} \\
\text { Height), } \pm 0.2 \mathrm{~m} \text {, Once a package size is selected, the dimension of all packages shall } \\
\text { be constant and have a dimensional tolerance of } \pm 0.01 \mathrm{~m} \text {. }\end{array}$ \\
\hline Mass & The mass of each package shall not exceed $10,000 \mathrm{~kg}$. \\
\hline Void Space & $\begin{array}{l}\text { The head space in the fully loaded package shall not exceed } 1 \text { percent of the total } \\
\text { internal volume of the container. A non-compactible filler material (screened to } 4 \\
\text { mesh size or smaller) may be used to meet this requirement. If the waste form and } \\
\text { matrix materials are loaded into the container in a manner that results in void spaces } \\
\text { between the emplaced pieces, the filler material shall be used to fill the void spaces. } \\
\text { If a filler material is used, it shall be compatible with the other materials in the } \\
\text { package. }\end{array}$ \\
\hline $\begin{array}{l}\text { Radionuclide } \\
\text { Concentration Limitations }\end{array}$ & $\begin{array}{l}\text { The average concentrations of }{ }^{137} \mathrm{Cs},{ }^{90} \mathrm{Sr} \text { and }{ }^{99} \mathrm{Tc} \text { shall be limited as follows: }{ }^{137} \mathrm{Cs}< \\
3 \mathrm{Ci} / \mathrm{m}^{3},{ }^{90} \mathrm{Sr}<20 \mathrm{Ci} / \mathrm{m}^{3} \text { and }{ }^{99} \mathrm{Tc}<0.3 \mathrm{Ci} / \mathrm{m}^{3} \text {. The average concentrations shall be } \\
\text { calculated by adding the inventories of each of the above radionuclides in the } \\
\text { packages that have been presented to date for acceptance and dividing by the total } \\
\text { volume of waste in these packages. }\end{array}$ \\
\hline $\begin{array}{l}\text { Surface Dose Rate } \\
\text { Limitations }\end{array}$ & $\begin{array}{l}\text { The dose rate at any point on the external surface of the package shall not exceed } \\
1,000 \mathrm{mrem} / \mathrm{hr} \text {. }\end{array}$ \\
\hline
\end{tabular}

the assumptions in the TWRSO\&UP (Kirkbride et al., 1997). Unlike the isotopes tracked in the TWRSO\&UP, the isotopes from the BBI are not separated into solid and liquid fractions. For this study, the BBI-based isotopes are assumed to be completely soluble in the supernatant and sludge wash liquids and follow the sodium into the ILAW package. This assumption provides a conservatively high estimate for the concentration and level of activity of radionuclides in the ILAW package. 
HNF-2110 Rev 0

Table 3-2. Assumptions Made for Base Case Scenario.

\begin{tabular}{|c|c|}
\hline Area of limited information & Assumptions \\
\hline $\begin{array}{l}\text { Tank Waste Retmediation System } \\
\text { Operation and Utilization Plan }\end{array}$ & $\begin{array}{l}\text { - The TWRSO\&UP is one of our data sources; therefore its assumptions } \\
\text { also are assumed for this study. }\end{array}$ \\
\hline Solubility of waste feed constituents & $\begin{array}{l}\text { - The solubility of the key isotopes }{ }^{137} \mathrm{Cs} \text { and }{ }^{90} \mathrm{Sr} \text { are based on the } \\
\text { assumptions in the TWRSO\&UP. } \\
\text { - The key isotopes }{ }^{60} \mathrm{Co},{ }^{106} \mathrm{Ru},{ }^{125} \mathrm{Sb},{ }^{126} \mathrm{Sn},{ }^{152} \mathrm{Eu} \text {, and }{ }^{154} \mathrm{Eu} \text { are } \\
\text { completely soluble and follow the sodium into the ILAW package for } \\
\text { Envelopes } \mathrm{A} \text { and } \mathrm{C} \text {. } \\
\text { - Ten percent of the }{ }^{60} \mathrm{Co}, 20 \text { percent of the }{ }^{125} \mathrm{Sb} \text { and five percent of the } \\
{ }^{152} \mathrm{Eu} \text { and }{ }^{154} \mathrm{Eu} \text { in tanks } \mathrm{AZ}-101 \text { and } \mathrm{AZ}-102 \text { (Envelope B) are in } \\
\text { solution. The }{ }^{106} \mathrm{Ru} \text { and }{ }^{126} \mathrm{Sn} \text { isotopes in } \mathrm{AZ}-101 \text { and } \mathrm{AZ}-102 \text { are } \\
\text { completely soluble. }\end{array}$ \\
\hline Radionuclide source term & $\begin{array}{l}\text { - Batches are discrete with no commingling between batches. } \\
\text { - Concentrations of }{ }^{137} \mathrm{Cs},{ }^{90} \mathrm{Sr} \text {, and }{ }^{92} \mathrm{Tc} \text { are held to their average } \\
\text { concentration limit }\left(3.0,20.0 \text { and } 0.3 \mathrm{Ci} / \mathrm{m}^{3} \text {, respectively) in accordance }\right. \\
\text { with Privatization Specification } 2 \text {, Section } 2.2 .2 .8 \text { (DOE-RC 1996). }\end{array}$ \\
\hline Waste form geometry & $\begin{array}{l}\text { - Waste form is glass (composition is LD6-5510), formed as marbles. } \\
\text { - Waste form is } 20 \mathrm{wt} \% \mathrm{Na}_{2} \mathrm{O} \text { for Envelopes } \mathrm{A} \text { and } \mathrm{C}, 8 \mathrm{wt} . \% \mathrm{Na}_{2} \mathrm{O} \text { for } \\
\text { Envelope } \mathrm{B} \text {. } \\
\text { - Waste volume is } 80 \mathrm{vol} \% \text { of the external package volume. } \\
\text { - Waste form has a specific gravity of } 2.65 \text {. } \\
\text { - No filler material or optional matrix materials in the ILAW package. }\end{array}$ \\
\hline Waste package size & - External dimensions of $1.8 \mathrm{~m}(\mathrm{l}) \times 1.2 \mathrm{~m}(\mathrm{w}) \times 1.2 \mathrm{~m}(\mathrm{~h}),\left(2.6 \mathrm{~m}^{3}\right)$. \\
\hline Waste container wall thickness & $\begin{array}{l}-1.27 \mathrm{~cm}(0.5 \mathrm{in} .) \text {. Graphically presented over a range from } 1.0 \text { to } \\
8.9 \mathrm{~cm}(0.4 \text { to } 3.5 \mathrm{in} .) \text {. }\end{array}$ \\
\hline $\begin{array}{l}\text { Contribution to dose rate from } \\
\text { neutron emission }\end{array}$ & - The contribution to the dose rate caused by neutrons is negligible. \\
\hline
\end{tabular}

Notes: TWRSO\&UP $=$ Tank Waste Remediation System Operation and Utilization Plan

ILAW = immobilized low-activity waste

Exceptions to this overly conservative assumption apply to the ${ }^{60} \mathrm{Co},{ }^{125} \mathrm{Sb},{ }^{152} \mathrm{Eu}$, and ${ }^{154} \mathrm{Eu}$ solubilities in tanks 241-AZ-101 and 241-AZ-102 (Envelope B). If these isotopes are assumed to be completely soluble for these tanks, their dose contribution would comprise more than 95 percent of the dose from the ILAW waste packages in Envelope B. The high dose rate of the Envelope B waste made it prudent to more accurately represent its true radionuclide inventory.

Unpublished concentration data (Esch 1998) from supernate samples taken in 1995 from these tanks reveal that most of the cobalt, antimony, and europium are in the solids. These solids will be removed from the ILAW feed and will be handled as high-level waste. The data show that less than 8 percent of ${ }^{60} \mathrm{Co}$, less than 17 percent of ${ }^{125} \mathrm{Sb}$, and less than 3 percent of ${ }^{154} \mathrm{Eu}$ will 


\section{HNF-2110 Rev 0}

be present in the supernate when it is transferred and separated from the solids. Therefore, this study will assume that for Envelope B (Tanks 241-AZ-101 and 241-AZ-102) the inventory in solution of the cobalt isotopes will be 10 percent, antimony isotopes will be 20 percent, and europium isotopes will be 5 percent of the BBI's inventory for those isotopes. Additional work is currently under way that will update the TWRSO\&UP and model the solubility of all the radionuclides in the $\mathrm{BBI}$.

\subsubsection{Radionuclide Source Term}

The base-case radionuclide concentration of the ILAW package is $3 \mathrm{Ci} / \mathrm{m}^{3}$ for ${ }^{137} \mathrm{Cs}$, which is the average concentration limit listed in Specification 2, Section 2.2.2.8. The other two average radionuclide concentration limits of Specification 2 are ${ }^{90} \mathrm{Sr}=20 \mathrm{Ci} / \mathrm{m}^{3}$ and ${ }^{99} \mathrm{Tc}=0.3 \mathrm{Ci} / \mathrm{m}^{3}$. The specific concentration for all three radionuclides will be reached in some of the waste packages. For these cases, the radionuclide concentrations will be assumed to be their average concentration limits.

The feed staging batches delivered to the private contractors are assumed to be discrete, with no commingling between batches. The scheduled batch transfers are significantly large and minimize downstream impacts or are scheduled to take advantage of low heels in the vendors' feed tanks at the beginning of a feed envelope. The large batch transfers will reduce the potential variability of significant contributors to the ILAW dose rate.

\subsubsection{Waste Form Geometry}

The base-case assumption of the encapsulated waste form is glass. The assumed composition of the glass is formulation LD6-5510 (20.00 wt $\% \mathrm{Na}_{2} \mathrm{O}, 1.52 \mathrm{wt} \% \mathrm{~K}_{2} \mathrm{O}$, $10.00 \mathrm{wt} \% \mathrm{Al}_{2} \mathrm{O}_{3}, 5.00 \mathrm{wt} \% \mathrm{~B}_{2} \mathrm{O}_{3}, 5.00 \mathrm{wt} \% \mathrm{CaO}, 56.78 \mathrm{wt} \% \mathrm{SiO}_{2}$ and $1.70 \mathrm{wt} \%$ "Other"). Differences in the composition of the glass are not anticipated to have an appreciable effect on the self-shielding characteristics of the glass or the dose rate.

The base-case assumption for waste form geometry is marbles. This waste form geometry is currently being used at Savannah River's M Area Remediation Site and will give a conservatively higher dose rate than the monolith and cullet waste forms.

The base-case assumption for waste loading is $73.1 \mathrm{~cm}^{3}$ of waste form per gram mole of sodium for Envelopes $\mathrm{A}$ and $\mathrm{C}$, and $182.75 \mathrm{~cm}^{3}$ of waste form per gram mole of sodium for Envelope B. These assumptions are based on U.S. Department of Energy (DOE) guidance provided in written communication from Brown (1996). Brown (1996), from which these values were derived, provides the following guidance:

- The waste form is $20 \mathrm{wt} \% \mathrm{Na}_{2} \mathrm{O}$ for Envelopes $\mathrm{A}$ and $\mathrm{C}$ and $8 \mathrm{wt} \% \mathrm{Na}_{2} \mathrm{O}$ for Envelope $\mathrm{B}$

- The waste volume is 80 vol. \% of the external package volume

- The waste form has a specific gravity of 2.65 . 


\section{HNF-2110 Rev 0}

The base-case assumption will also comply with the waste loading guidance in Specification 2, Section 2.2.2.2 (DOE-RL 1996). This specification defines the lower limit of sodium loading for the waste form based on the external package dimensions. This specification does not preclude the private contractors from using higher sodium loadings. By being based on the external package dimensions, this specification is written such that the sodium loading within the waste form itself (marbles, monoliths) is vague.

For this study, the total sodium loading of the waste form will be based on the external dimensions of the package despite which waste form geometry is used. This gives waste packages with a constant sodium inventory per package, but actual sodium loading within the glass itself would vary with the waste form studied. This basis explains why the total package count is unaffected by the change from the base case waste form (marbles) to the sensitivity case waste form (monoliths) presented in Section 4.6.

The base-case assumption for filler material is no filler material in the ILAW package. The use of a small marble waste form geometry would not require the use of filler material to fill void spaces of the package per Specification 2, Section 2.2.2.5 (DOE-RL 1996).

The base-case assumption on head space above the waste form is maximum 1 percent of the total internal volume of the container. This precludes the need for a filler material per Specification 2, Section 2.2.2.5 (DOE-RL 1996). The addition of filler materials would decrease the dose rate.

The base-case assumption is no use of optional matrix materials as allowed per Specification 2, Section 2.2.2.1 (DOE-RL 1996).

\subsubsection{Waste Package Size}

The base-case assumption is a package with external dimensions of $1.8 \mathrm{~m}(1) \times 1.2 \mathrm{~m}(\mathrm{w})$ $\times 1.2 \mathrm{~m}(\mathrm{~h})\left(2.6 \mathrm{~m}^{3}\right)$ based on Specification 2, Section 2.2.2.3 (DOE-RL 1996), the median case. The base-case assumption is the mass of the package will not exceed $10,000 \mathrm{~kg}$ based on Specification 2, Section 2.2.2.4 (DOE-RL 1996).

\subsubsection{Waste Container Wall Thickness}

The base-case assumption for the wall thickness of the waste container is $1.27 \mathrm{~cm}$ ( 0.5 in.). This wall thickness is reasonably conservative and is the same thickness used in a related study of ILAW produced from Tank AN-107 waste (Holton 1997). The fixed wall thickness will be used to compare the results of the various sensitivity cases to the base case. However, unit dose rate information is available over a range of wall thicknesses, from 1.0 to $8.9 \mathrm{~cm}$ ( 0.4 to $3.5 \mathrm{in}$.) (Savino 1998). Graphical data for the different cases will be presented over this range. 
HNF-2110 Rev 0

\subsubsection{Contribution to Dose Rate from Neutron Emission}

The contribution to the dose rate caused by neutrons is assumed to be negligible. This assumption is based on a study performed by Savino (1998) of the neutron dose rate from the ILAW packages. In this study, the neutron dose rate was less than 0.01 percent of the gamma dose rate and, therefore, does not need to be accounted for separately in the evaluation of the dose rates outside the package.

\subsection{UNCERTAINTIES}

Uncertainties are identified where insufficient information exists to perform a required analysis. The main uncertainties identified in this analysis are described in the following sections.

\subsubsection{Cesium Separations Efficiency}

Cesium removal will be required to meet the ILAW specification of $3.0 \mathrm{Ci} / \mathrm{m}^{3}{ }^{137} \mathrm{Cs}$. The decontamination factor (DF) required to meet the concentration limit range from 75 to 207 for Envelopes A and C, and is around 827 for Envelope B. The private contractors' might exceed the required DFs for some of these batches. The actual DFs may reduce the dose rates of some batches to reclassify the ILAW packages as contact handled. Section 4.3 presents the sensitivity of dose rate to cesium separation efficiency.

\subsubsection{Waste Form Geometry}

The base-case waste form geometry for this study is marbles. The other waste form geometries considered were monoliths and cullet. The marble geometry provides less selfshielding and thus a higher dose rate than the other geometries. The monolith and cullet would have a lower dose rate provided by greater self-shielding. The monolithic waste form will be studied as a sensitivity case in this study. Section 4.6 presents the results of this sensitivity case.

\subsubsection{Waste Package Size}

The base-case waste package size is $1.8 \mathrm{~m} \times 1.2 \mathrm{~m} \times 1.2 \mathrm{~m}$ based on the nominal dimensions of the privatization specification. The privatization specification allows a contractor to deviate from these dimensions $\pm 0.2 \mathrm{~m}$ for each side. It also requires the dimensions of all the packages to be constant and have a dimensional tolerance of $\pm 0.01 \mathrm{~m}$ once a package size is selected. The dimensions of a package are anticipated to have a minimal effect on the surface dose rate of the package as long as the container wall thickness remains constant. However, the size of the package is indirectly proportional to the maximum allowable shielding thickness of the container because of the $10,000 \mathrm{~kg}$ mass limitation of the package. Section 4.7 analyzes the sensitivity of dose rate to package size. 
HNF-2110 Rev 0

\subsubsection{Waste Container Wall Thickness}

The base-case wall thickness is $1.27 \mathrm{~cm}(0.5 \mathrm{in}$.$) and is based on a reasonably$ conservative assumption (Section 3.2.6). The wall thickness of the container has a significant effect on the dose rate. Section 4.2 analyzes the sensitivity of dose rate to wall thickness.

\subsubsection{Waste Package Dose Rate Distribution}

The base-case assumes the radionuclides in the waste form are homogenous for each batch. It is unlikely that the waste within an entire batch would be homogenous, but the variability is unknown. As the waste within a batch becomes less homogenous, there is a greater potential that some of the waste packages assumed to be contact handled (surface dose rate $<200 \mathrm{mrem} / \mathrm{h}$ ) could have a higher dose rate and be reclassified as remote-handled waste. However, this reasoning also holds true for the opposite case; some of the remote-handled batch may qualify to become contact handled. Therefore, the effect of this uncertainty depends on the relative amounts of remote- and contact-handled wastes and how close the waste packages in a batch are to the $200 \mathrm{mrem} / \mathrm{h}$ surface dose rate. 
HNF-2110 Rev 0

\subsection{SOURCE TERM AND DOSE RATE ANALYSIS}

This section presents the results of this study. The base-case results are presented first followed by results of analyses on sensitivity cases. The sensitivity cases studied are waste container wall thickness, cesium separation efficiency, lower and higher waste loadings, waste form geometry and waste package size. Table 4-1 summarizes the results.

Dose rate contributions for unit concentrations of each key radionuclide were determined by Savino (1998). The unit dose rates were presented as a function of package wall thickness ranging from 1.0 to $8.9 \mathrm{~cm}$ ( 0.4 to $3.5 \mathrm{in}$.) and based on a steel-walled container.

\subsection{BASE CASE}

\subsubsection{Base-Case Radionuclide Source Term}

The radionuclide source term for the base case is based on the assumptions listed in Section 3.2. The source term lists the concentrations of the radionuclides of concern for each batch. The unit used for reporting the source term is curies per cubic meter of ILAW volume in the waste packages. The source term data are presented in Appendix A on page A-5.

\subsubsection{Base-Case Dose Rate Distribution}

The dose rate calculations were performed for uniformly distributed radionuclides in a $1.2 \mathrm{~m} \mathrm{x} 1.2 \mathrm{~m} \mathrm{x} 1.8 \mathrm{~m}$ container with steel walls measuring $1.27 \mathrm{~cm}(0.5 \mathrm{in}$ ) thick. For Envelope A, the dose rates from the ILAW packages ranged from 374 to $538 \mathrm{mrem} / \mathrm{hr}$. For Envelope C, the range of dose rates was broader, ranging from 352 to $599 \mathrm{mrem} / \mathrm{hr}$. The dose rate from Envelope B was by far the highest at $999 \mathrm{mrem} / \mathrm{hr}$, which by the slimmest margin, met the criteria (dose rate $\leq 1,000 \mathrm{mrem} / \mathrm{hr}$.) to be acceptable as ILAW.

\subsubsection{Base-Case Remote-Handled and Contact-Handled Package Counts}

The Phase 1 package count for the base case is 11,370 packages. The base-case evaluation results in all the Phase 1 ILAW packages having surface dose rates of greater than or equal to 200 mrem per hour ( 100 percent remote-handled waste) and will require shielded transport and disposal in shielded underground vaults. The results support early studies by Eiholzer (1995), Mitchell (1995), and Mann et al. (1997).

\subsection{EFFECT OF WASTE CONTAINER WALL THICKNESS}

The waste container wall thickness is an important factor in this study. A thicker wall provides better radiation shielding at the expense of a reduced internal volume to waste container size (increased package count) and increased package weight. A sensitivity case is presented 
Table 4-1. Summary of Results for all Cases.

\begin{tabular}{|c|c|c|c|c|c|c|c|c|c|}
\hline Case & $\begin{array}{c}\mathrm{CH} \text { packages, } \\
\text { count }(\%)\end{array}$ & $\begin{array}{l}\text { RH packages, } \\
\text { count }(\%)\end{array}$ & $\begin{array}{c}\text { Total package } \\
\text { count }\end{array}$ & Cesium DF & Waste loading & Decay date & $\begin{array}{l}\text { Waste form } \\
\text { geometry }\end{array}$ & $\begin{array}{c}\text { Package size, } \\
\text { LxWxH, } \\
\text { m }\end{array}$ & $\begin{array}{l}\text { Max wall } \\
\text { thickness, } \\
\mathrm{cm} \text { (in.) }\end{array}$ \\
\hline Base case & $0(0)$ & $11,370(100)$ & 11,370 & base case & base case & $7 / 1 / 2002$ & marbles & $1.8 \times 1.2 \times 1.2$ & $8.9(3.5)$ \\
\hline$C s \mathrm{DF}=210$ & $O(0)$ & $11,370(100)$ & 11,370 & $\begin{array}{c}210 \text { (Env. } \\
\text { A\&C) }\end{array}$ & base case & $7 / 1 / 2002$ & marbles & $1.8 \times 1.2 \times 1.2$ & $8.9(3.5)$ \\
\hline $\mathrm{Cs} \mathrm{DF}=300$ & $2,264(19.9)$ & $9,106(80.1)$ & 11,370 & $\begin{array}{c}300 \text { (Env. } \\
\text { A.\&C) }\end{array}$ & base case & $7 / 1 / 2002$ & marbles & $1.8 \times 1.2 \times 1.2$ & $8.9(3.5)$ \\
\hline $\mathrm{Cs} D F=1,000$ & $7,163(62.8)$ & $4,227(37.2)$ & 11,370 & 1,000 & base case & $7 / 1 / 2002$ & marbles & $1.8 \times 1.2 \times 1.2$ & $8.9(3.5)$ \\
\hline $\begin{array}{l}\text { Realistic } \\
\text { decay dates }\end{array}$ & $O(0)$ & $11,370(100)$ & 11,370 & base case & base case & $\begin{array}{c}\text { batch feed } \\
\text { delivery date }\end{array}$ & marbles & $1.8 \times 1.2 \times 1.2$ & $8.9(3.5)$ \\
\hline $\begin{array}{l}\text { Realistic } \\
\text { decay dates } \\
\text { and } \\
\text { Cs } D F=1,000\end{array}$ & $8,649(76.1)$ & $2,721(23.9)$ & 11,370 & 1,000 & base case & $\begin{array}{l}\text { batch feed } \\
\text { delivery date }\end{array}$ & marbles & $1.8 \times 1.2 \times 1.2$ & $8.9(3.5)$ \\
\hline $\begin{array}{l}\text { Low waste } \\
\text { loading }\end{array}$ & $0(0)$ & $15,550(100)$ & 15,550 & base case & minimum & $7 / 1 / 2002$ & marbles & 1. $8 \times 1.2 \times 1.2$ & $8.9(3.5)$ \\
\hline $\begin{array}{l}\text { High waste } \\
\text { loading }\end{array}$ & $0(0)$ & $9,101(100)$ & 9,101 & base case & maximum & $7 / 1 / 2002$ & marbles & $1.8 \times 1.2 \times 1.2$ & $8.9(3.5)$ \\
\hline $\begin{array}{l}\text { Monolithic } \\
\text { waste } \\
\text { geometry }\end{array}$ & $0(0)$ & $11,370(100)$ & 11,370 & base case & base case & $7 / 1 / 2002$ & monoliths & $1.8 \times 1.2 \times 1.2$ & $5.7(2.2)$ \\
\hline $\begin{array}{l}\text { Large package } \\
\text { size }\end{array}$ & $0(0)$ & $7,542(100)$ & 7,542 & base case & base case & $7 / 1 / 2002$ & marbles & $2.0 \times 1.4 \times 1.4$ & $3.5(1.4)$ \\
\hline
\end{tabular}

Notes:

$\mathrm{CH}=$ contact-handled

$\mathrm{RH}=$ remote-handled

Contact- and remote-handled package counts are based on a $1.27 \mathrm{~cm}(0.5 \mathrm{in}$.) package wall thickness. 
HNF-2110 Rev 0

that shows the effect of changing the wall thickness on the resulting contact- and remote-handled package counts.

\subsubsection{Dose Rate Distribution}

This sensitivity case is essentially the base-case scenario analyzed for package wall thicknesses ranging from 1.0 to $8.9 \mathrm{~cm}(0.4$ to $3.5 \mathrm{in}$.). Figure $4-1$ shows the percent of ILAW packages that are contact-handled over a range of wall thickness. This sensitivity case will be used to represent the base case in comparisons with the rest of the sensitivity cases.

\subsubsection{Remote-Handled and Contact-Handled Package Counts}

The Phase 1 ILAW package count is 100 percent remote-handled at wall thicknesses up to $2.2 \mathrm{~cm}(0.9 \mathrm{in}$.). As the wall thickness is increased from 2.2 to $3.4 \mathrm{~cm}(1.3 \mathrm{in}$.), the contacthandled package count shoots up from 0 percent to 93.7 percent. This demonstrates how sensitive the dose rate (and package classification as contact-handleable) is to the package wall thickness. The remaining 6.3 percent of the packages (all from Envelope B) also become contact handled when the wall thickness is finally increased to $4.3 \mathrm{~cm}(1.7 \mathrm{in}$.).

\subsection{EFFECT OF CESIUM SEPARATION EFFICIENCY}

\subsubsection{Radionuclide Source Term}

The-base case cesium separation efficiency was increased to evaluate the impact of lower

${ }^{137} \mathrm{Cs}$ concentrations on dose rate distribution and the number of remote-handled and contacthandled waste packages. The base-case cesium separation efficiencies (DF) to meet the concentration limit of $3 \mathrm{Ci} / \mathrm{m}^{3}$ of ${ }^{137} \mathrm{Cs}$ range from 75 to 207 for Envelopes $\mathrm{A}$ and $\mathrm{C}$, and is about 827 for Envelope B. Three sensitivity cases were analyzed based on cesium DFs of 210, 300, and 1,000. The source term data for these sensitivity cases are presented in Appendix A on pages A-6 through A-8.

\subsubsection{Dose Rate Distribution}

The dose rate calculations were performed in the same manner as those for the base case. The only changes in the calculations were the cesium DFs. The details for the three sensitivity cases at the base-case wall thickness of $1.27 \mathrm{~cm}$ are listed in Table 4-2. Figure 4-2 shows the percent of ILAW packages that are contact handled for these sensitivity cases.

\subsubsection{Remote-Handled and Contact-Handled Package Counts}

Table 4-2 summarizes the cesium DF results for sensitivity cases 1, 2, and 3. All the 11,370 waste packages are remote handled based on a cesium DF of 210 for Envelopes A and C and a cesium DF of about 827 for Envelope B. About 20 percent $(2,264)$ of the waste packages 
HNF-2110 Rev 0

Figure 4-1. Contact Handled ILAW Packages vs. Package Wall Thickness for the Base Case.

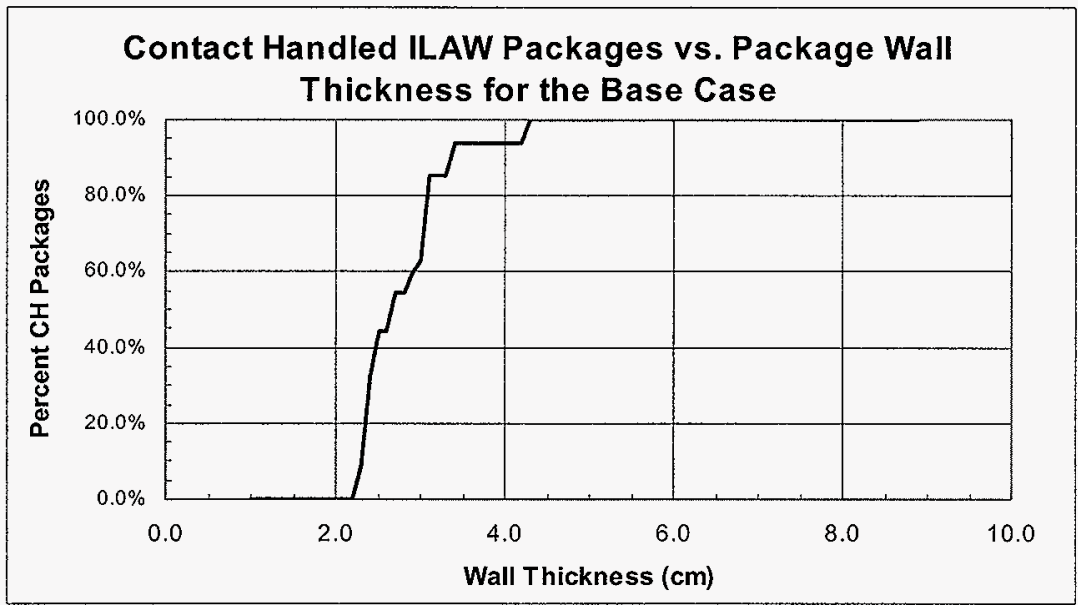

Figure 4-2. Contact Handled ILAW Packages Relative to Cesium Removal Efficiency.

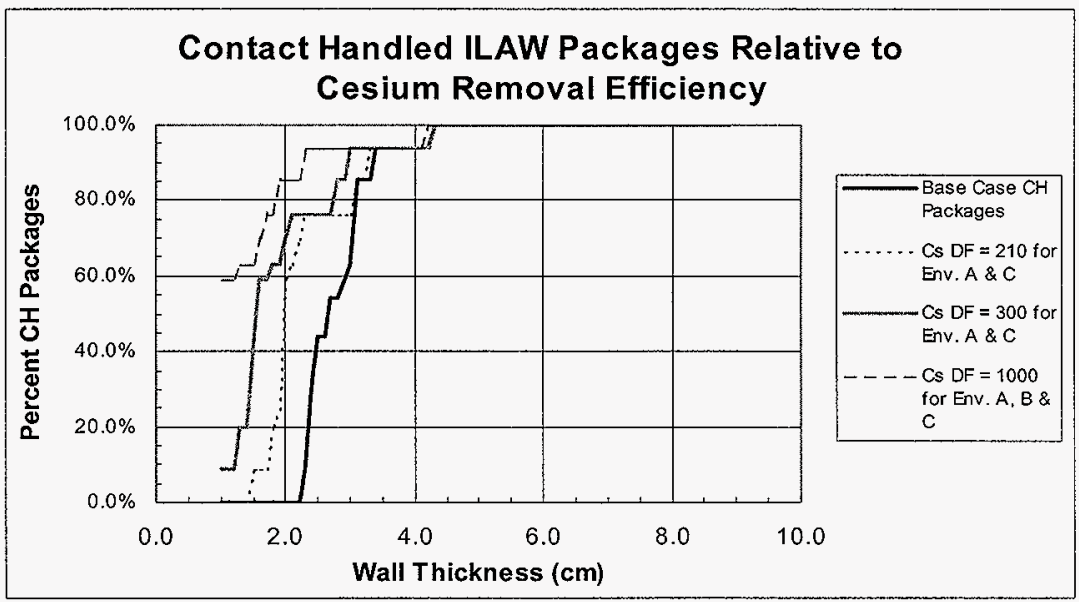




\section{HNF-2110 Rev 0}

become contact handled by increasing the cesium DF to 300 for Envelopes A and C and maintaining the cesium DF at about 827 for Envelope B. About 63 percent $(7,143)$ of the waste packages are contact handled based on a cesium DF of 1,000 for Envelopes A, B, and C. As more cesium is removed at the lower DFs, more of the Phase 1 ILAW packages become contact handled. However, some of the batches within Phase 1 cannot have their dose rate lowered enough to become contact handled with higher cesium DFs alone. Increasing the cesium DF beyond 1,000 will not reclassify these batches as contact handled. These batches (primarily in Envelope B) contain appreciable amounts of ${ }^{154} \mathrm{Eu},{ }^{60} \mathrm{Co}$, and in some cases ${ }^{125} \mathrm{Sb}$ that contribute a significant amount of the dose rate. Significant reduction in the dose rate for these batches will require other means teamed with increased cesium removal.

Table 4-2. Remote- and Contact-Handled Package Counts for Cesium Separation Efficiency Sensitivity Cases.

\begin{tabular}{|c|c|c|c|c|}
\hline \multirow{2}{*}{$\begin{array}{l}\text { Sensitivity } \\
\text { case }\end{array}$} & \multicolumn{2}{|c|}{ Decontamination factor } & \multirow{2}{*}{$\begin{array}{l}\text { Contact-handled } \\
\text { packages, } \\
\text { count }(\%)\end{array}$} & \multirow{2}{*}{$\begin{array}{l}\text { Remote-handlec } \\
\text { packages, } \\
\text { count }(\%)\end{array}$} \\
\hline & $\begin{array}{c}\text { Envelopes } \\
\mathrm{A} \text { and } \mathrm{C}\end{array}$ & $\begin{array}{c}\text { Envelope } \\
\text { B }\end{array}$ & & \\
\hline Base case & $\begin{array}{l}\text { Base case } \\
(\sim 75-207)\end{array}$ & $\begin{array}{c}\text { Base case } \\
\quad(\sim 827)\end{array}$ & $0(0)$ & $11,370(100)$ \\
\hline 1 & 210 & $\begin{array}{c}\text { Base case } \\
(\sim 827)\end{array}$ & $0(0)$ & $11,370(100)$ \\
\hline 2 & 300 & $\begin{array}{c}\text { Base case } \\
\quad(\sim 827)\end{array}$ & $2,264(19.9)$ & $9,106(80.1)$ \\
\hline 3 & 1,000 & 1,000 & $7,143(62.8)$ & $4,227(37.2)$ \\
\hline
\end{tabular}

\subsection{EFFECT OF DECAYING WASTE TO FEED DELIVERY DATE BY BATCH}

\subsubsection{Radionuclide Source Term}

This sensitivity case decays the radionuclides for a batch to the feed delivery date for that batch. This case was evaluated as the alternative to the single decay date for the base case (July 1,2002). This section discusses the effect of changing the decay dates on dose rate distribution and the number of remote-handle and contact-handled packages. Another sensitivity case that combines the effects of decaying the waste to the feed delivery date by batch and enhanced cesium separation also is studied. The source terms for these sensitivity cases are presented in Appendix A on pages A-9 and A-10. 
HNF-2110 Rev 0

\subsubsection{Dose Rate Distribution}

The dose rate calculations were performed for uniformly distributed radionuclides in a $1.2 \mathrm{~m} \times 1.2 \mathrm{~m} \times 1.8 \mathrm{~m}$ container with steel walls measuring $1.27 \mathrm{~cm}(0.5 \mathrm{in}$.) thick. For Envelope A, the dose rates from the ILAW packages ranged from 367 to $516 \mathrm{mrem} / \mathrm{hr}$. For Envelope C, the range of dose rates was broader, ranging from 350 to $541 \mathrm{mrem} / \mathrm{hr}$. The dose rate from Envelope B was the highest at $795 \mathrm{mrem} / \mathrm{hr}$.

It should be noted that the dose rate contributions from ${ }^{137} \mathrm{Cs}$ and, for some batches (to a much lesser degree), ${ }^{90} \mathrm{Sr}$ are not affected by the different decay dates in this sensitivity case. However, using the batch-specific decay dates reduces the DFs required to remove ${ }^{137} \mathrm{Cs}$ and ${ }^{90} \mathrm{Sr}$ to meet the ILAW specifications. An interesting case is shown by combining the effect of this sensitivity case with that of the cesium removal sensitivity case (Section 4.3 , cesium $\mathrm{DF}=1,000$ ). Figure 4-3 shows the percent of ILAW packages that are contact handled over a range of wall thicknesses for this sensitivity case.

\subsubsection{Remote-Handled and Contact-Handled Package Counts}

The total package count for this sensitivity case is 11,370 packages, the same as the base case. Even with the lower dose rate from the decay dates being adjusted for each individual batch, all the Phase 1 ILAW packages still have surface dose rates of greater than or equal to 200 mrem per hour (100 percent remote-handled waste) and therefore will require shielded transport and disposal in shielded underground vaults.

Results from the combined sensitivity case (cesium $\mathrm{DF}=1,000$ and radionuclides decayed by individual batch) show how well the two factors compliment each other. With just a cesium DF of 1,000 (wall thickness of $1.27 \mathrm{~cm}$ ), the percent of ILAW packages that are contact handleable is 62.8 percent (note: higher DFs alone will not yield more $\mathrm{CH}$ packages). When the radionuclides also are decayed to each batch's feed delivery date, the percent of ILAW packages that are contact handleable increases to 76.1 percent, an increase of 13.3 percent $(1,506$ packages).

\subsection{EFFECT OF CHANGES IN WASTE LOADING}

This sensitivity case studies the effect of varying the waste loading on the number of remote- and contact-handled packages. The two sensitivity cases evaluated are when the sodium loading is both minimized to the limits specified in the privatization specification and maximized to the practical upper limit that retains good glass performance.

\subsubsection{Radionuclide Source Term}

The base case assumes a sodium loading of $73.1 \mathrm{~cm}^{3}$ of waste package per gram mole of sodium $\left(20 \mathrm{wt} . \% \mathrm{Na}_{2} \mathrm{O}\right.$ ) for Envelopes $\mathrm{A}$ and $\mathrm{C}$, and a sodium loading of $182.75 \mathrm{~cm}^{3}$ of waste 
HNF-2110 Rev 0

package per gram mole of sodium ( $8 \mathrm{wt} . \% \mathrm{Na}_{2} \mathrm{O}$ ) for Envelope B. Privatization Specification 2 (DOE-RL 1996) allows a contractor to lower the sodium loading to $100 \mathrm{~cm}^{3}$ of waste package per gram mole of sodium for Envelopes $A$ and $C$, and a sodium loading of $250 \mathrm{~cm}^{3}$ of waste package per gram mole of sodium for Envelope $\mathrm{B}$. This corresponds to $14.6 \mathrm{wt} \% \mathrm{Na}_{2} \mathrm{O}$ in the waste form for Envelopes $\mathrm{A}$ and $\mathrm{C}$, and $5.8 \mathrm{wt} \% \mathrm{Na}_{2} \mathrm{O}$ in the waste form for Envelope B. This will serve as the lower waste loading sensitivity case. The higher waste loading sensitivity case to be analyzed has the sodium loading increased to $58.5 \mathrm{~cm}^{3}$ of waste package per gram mole of sodium for Envelopes $\mathrm{A}$ and $\mathrm{C}$, and a sodium loading of $146.25 \mathrm{~cm}^{3}$ of waste package per gram mole of sodium for Envelope B. This corresponds to $25 \mathrm{wt}, \% \mathrm{Na}_{2} \mathrm{O}$ in the waste form for Envelopes A and C, and $10 \mathrm{wt} . \% \mathrm{Na}_{2} \mathrm{O}$ in the waste form for Envelope B. These two sensitivity cases will show the relative effect of reducing or increasing the waste loading on the dose rate of the Phase I ILAW. The source terms for these sensitivity cases are presented in Appendix A on pages $\mathrm{A}-11$ and $\mathrm{A}-12$.

\subsubsection{Dose Rate Distribution}

The dose rate calculations were performed in the same manner as those for the base case. The only changes in the calculations were the sodium loadings. Table 4-3 lists the details for the two sensitivity cases at the base case wall thickness of $1.27 \mathrm{~cm}$. Figure 4-4 shows the percent of ILAW packages that are contact-handled for these sensitivity cases.

\subsubsection{Remote-Handled and Contact-Handled Package Counts}

Table 4-3 presents the results of the calculations performed on the two sodium loading sensitivity cases. For both extremes of waste loading, the package counts remain at 100 percent remote handled. The most notable effect of varying the waste loading shown in the table is the change in the total number of ILAW packages. When the waste loading is lowered to the level allowed by the privatization specification, the total package count increases to 15,550 packages, a 36.8 percent increase from the 11,370 packages of the base case. Likewise, when the waste loading is increased to its practical upper limit, the total package count decreases to 9,101 packages, a 20.0 percent decrease from the base case.

Another observation that can only be gleaned from the graph in Figure 4-4 is the change in the sensitivity of the contact-handled package count (and dose rate) to varying wall thicknesses for various waste loadings. The graph shows that the ILAW packages remain remote handled up to a wall thickness of $2.2 \mathrm{~cm}(0.9 \mathrm{in}$.) regardless of the waste loading. However, an increase in the wall thickness to $3.9 \mathrm{~cm}$ (1.5 in.) will reclassify all the low waste loading ILAW as contact handled. For the high waste loading ILAW, a wall thickness of $4.6 \mathrm{~cm}$ (1.8 in.) is required to achieve the same result. 
HNF-2110 Rev 0

Figure 4-3. Effect of Decaying ILAW Source Term to Feed Delivery Date on CH Packages.

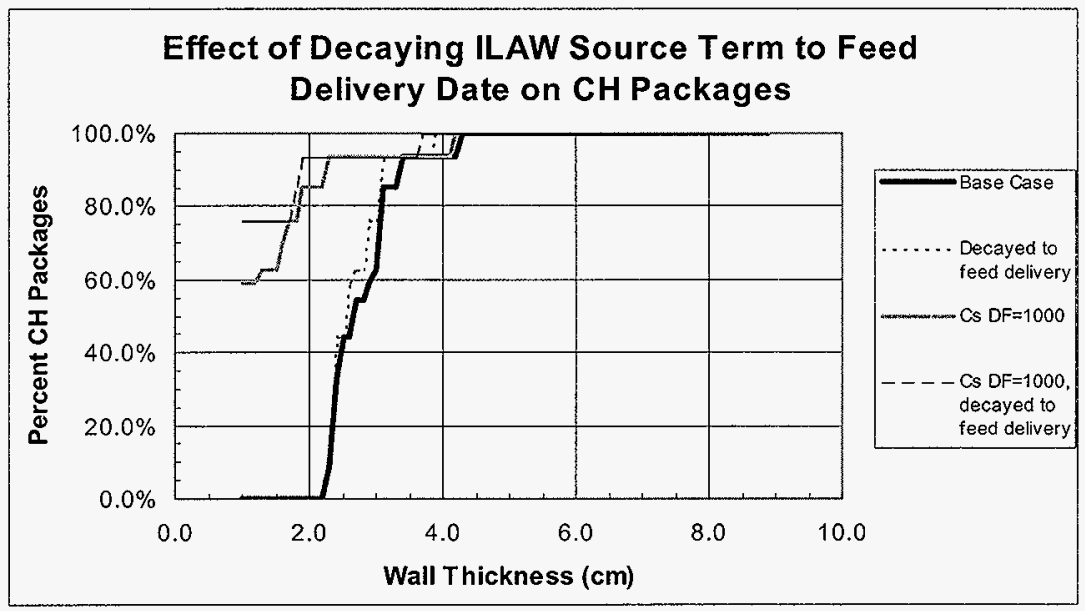

Figure 4-4. Effect of Waste Loadings on Contact Handled Package Count.

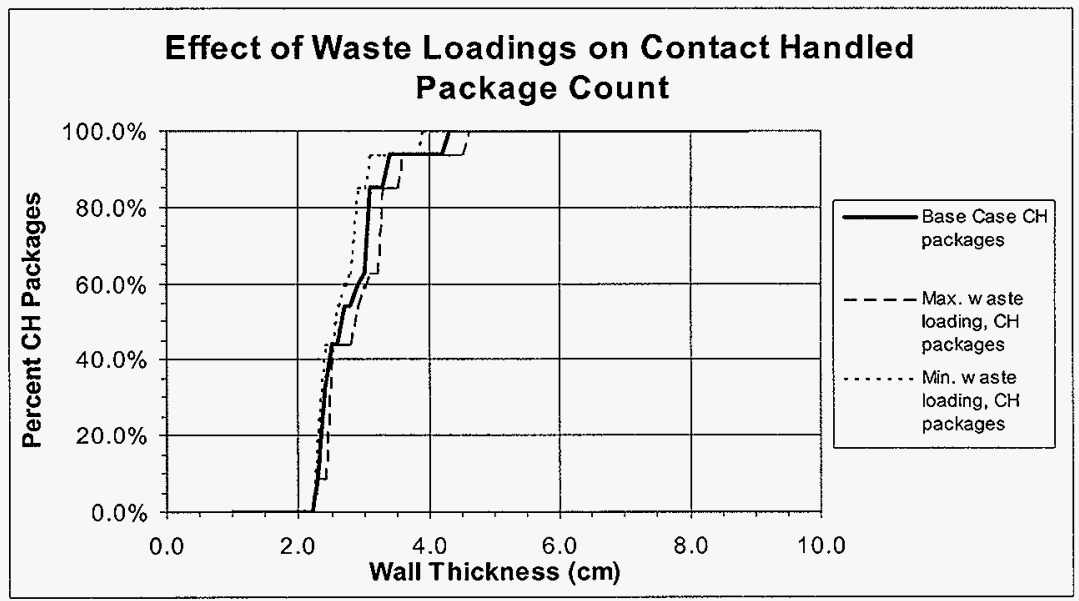


HNF-2110 Rev 0

Table 4-3. Remote- and Contact-Handled Package Counts for Waste Loading Sensitivity Cases.

\begin{tabular}{|c|c|c|c|c|c|}
\hline \multirow{2}{*}{$\begin{array}{l}\text { Sensitivity } \\
\text { case }\end{array}$} & \multicolumn{2}{|c|}{$\begin{array}{l}\mathrm{cm}^{3} \text { waste/gmol Na } \\
\text { (percent } \mathrm{Na}_{2} \mathrm{O} \text { ) }\end{array}$} & \multirow{2}{*}{$\begin{array}{c}\text { Contact } \\
\text { handled } \\
\text { packages, } \\
\text { count }(\%)\end{array}$} & \multirow{2}{*}{$\begin{array}{c}\text { Remote } \\
\text { handled } \\
\text { packages, } \\
\text { count (\%) }\end{array}$} & \multirow{2}{*}{$\begin{array}{l}\text { Total } \\
\text { packages, } \\
\text { count }\end{array}$} \\
\hline & $\begin{array}{l}\text { Envelopes } \\
\text { A \& C (\%) }\end{array}$ & $\begin{array}{c}\text { Envelope } \\
\text { B (\%) }\end{array}$ & & & \\
\hline $\begin{array}{c}\text { Low } \\
\text { waste load }\end{array}$ & $100(14.6)$ & $250(5.8)$ & $0(0)$ & $15,550(100)$ & 15,550 \\
\hline Base case & $73.1(20.0)$ & $182.75(8.0)$ & $0(0)$ & $11,370(100)$ & 11,370 \\
\hline $\begin{array}{l}\text { High waste } \\
\text { load }\end{array}$ & $58.5(25.0)$ & $146.25(10.0)$ & $0(0)$ & $9,101(100)$ & 9,101 \\
\hline
\end{tabular}

\subsection{EFFECT OF WASTE FORM GEOMETRY}

The monolithic waste form was evaluated as the alternative to marbles. This section discusses the effect of the monolithic waste form on dose rate distribution and the number of remote-handle and contact-handled packages.

\subsubsection{Radionuclide Source Term}

This sensitivity case required recalculation of the unit dose rate values for the monolithic waste form. The results of this recalculation, performed in Savino (1998), found that the dose rates are essentially reduced by one-third when changing from a composition of 67 percent glass $/ 33$ percent air (marbles) to 100 percent glass (monoliths) by volume. Other than this, the dose rate calculations were performed in the same manner as those for base case. The source term for this sensitivity case is presented in Appendix A on page A-13.

\subsubsection{Dose Rate Distribution}

For Envelope A, the dose rates from the ILAW packages ranged from 249 to $358 \mathrm{mrem} / \mathrm{hr}$. For Envelope $\mathrm{C}$, the range of dose rates was broader, ranging from 235 to $399 \mathrm{mrem} / \mathrm{hr}$. The dose rate from Envelope B was still the highest at $666 \mathrm{mrem} / \mathrm{hr}$, but was much lower than the base case scenario where it barely met the specifications for ILAW.

\subsubsection{Remote-Handled and Contact-Handled Package Counts}

The total package count for this sensitivity case is 11,370 packages, the same as the base case. Even with the lower dose rate from the monolithic waste form, all the Phase 1 ILAW 
HNF-2110 Rev 0

packages have surface dose rates of greater than or equal to 200 mrem per hour (100 percent remote-handled waste) and will require shielded transport and disposal in shielded underground vaults. However, the outcome of this scenario has 6,176 packages ( 54 percent) having a dose rate of between 200 and $300 \mathrm{mrem} / \mathrm{hr}$ compared to zero packages ( 0 percent) for the base case. This shows that a large number of the packages will be closer to being classified as contact handled under this scenario.

As stated in Section 3.2.4, the total sodium loadings of the waste forms in this study are based on the external dimensions of the packages. For this sensitivity case, the sodium loading within the waste form (monoliths) is 67 percent of the loading of the base case waste form (marbles). The total sodium within a package remains the same however. This basis explains why the total package count is unaffected by the change from the waste form for this sensitivity case.

\subsection{EFFECT OF WASTE PACKAGE SIZE}

The base-case waste package size $(1.8 \mathrm{~m} \times 1.2 \mathrm{~m} \times 1.2 \mathrm{~m})$ was increased to the limit allowed in the privatization specification $(2.0 \mathrm{~m} \times 1.4 \mathrm{~m} \times 1.4 \mathrm{~m})$. This size package was studied to determine the impact on the dose rate distribution and the resulting remote-handled and contact-handled package counts. The larger waste package size corresponds to the waste package size used in the Preliminary Safety Evaluation of the handling of the ILAW packages (FDNW 1997).

As stated in Section 3.3.3, the maximum waste container wall thickness depends on the waste package size and weight limit $(10,000 \mathrm{~kg})$. The thickest wall that could be used for a maximum size $(2.0 \mathrm{~m} \times 1.4 \mathrm{~m} \times 1.4 \mathrm{~m})$ waste container is $3.5 \mathrm{~cm}$. This value is based on a steel wall container with a steel density of $7.8 \mathrm{~g} / \mathrm{cm}^{3}$, waste in the form of marbles with a density of $2.65 \mathrm{~g} / \mathrm{cm}^{3}$, a void space of 33.3 percent, and the $10,000 \mathrm{~kg}$ maximum weight limit. If similar assumptions are used for a monolithic waste form (void space of 0 percent) in the same size container, the mass of the waste form (waste and package) is greater than $10,000 \mathrm{~kg}$ for any container wall thickness.

\subsubsection{Dose Rate Distribution}

This sensitivity case required recalculation of the unit dose rate values for the larger package size. The results of this recalculation, performed in Savino (1998), found that the change in dose rate versus package wall thickness was found to be negligible when increasing the package size from the base-case size to the size in this sensitivity case. The unit dose rates for the base case also are valid for this sensitivity case. Therefore, the dose rate calculations for this sensitivity case are the same as for the base case (Section 4.1.2). 
HNF-2110 Rev 0

\subsubsection{Remote-Handled and Contact-Handled Package Counts}

The effect of the larger package size does not affect the percent breakdown of the ratio of contact- to remote-handled waste. It remains the same as the base case (Section 4.1.3) at 100 percent remote handled. It does, however, reduce the total number of packages because more waste is placed in each individual package. The total package count for this scenario is 7,542 , which is 33 percent less than the total package count for the base case $(11,370)$. 
HNF-2110 Rev 0

\subsection{SUMMARY AND CONCLUSIONS}

Results from this engineering study are based on the assumptions listed in Section 3.2. One of these assumptions was that the wall thickness of the ILAW packages would be $1.27 \mathrm{~cm}$ (0.5 in.) although wall thicknesses ranging from 1.0 to $8.9 \mathrm{~cm}$ are encompassed in this study. One of our findings was how sensitive the dose rate of the entire group of Phase 1 ILAW packages was to the package wall thickness. This sensitivity is quite evident by the steepness of the curves shown in the figures in Section 4. Because of this sensitivity, it should be noted that the remaining conclusions from this study are based on our assumed wall thickness of $1.27 \mathrm{~cm}$.

This engineering study revealed that at least 50 percent of the waste most likely will be contact handled. This conclusion is based on the sensitivity case in which the cesium $D F=1,000$ and the radionuclides in each batch were decayed to their feed delivery date to the private contractors. This sensitivity case is considered representative of the actual conditions that the ILAW will be processed under based on our current knowledge. The cesium DF of 1,000 is only $20 \%$ greater than the $\mathrm{DF}$ of $\sim 827$ required to meet the privatization specification for Envelope $\mathrm{B}$. It would be reasonable to assume that the privatization contractors would build at least this much excess capacity into their design for cesium removal and would use this capacity for all the ILAW feed. The validity of using actual dates for decay purposes is obvious.

This sensitivity case also revealed that not less than 25 percent of the ILAW packages will be remote handled unless additional removal of radionuclides is undertaken. The ILAW feeds contain other gamma-emitting radionuclides that contribute significantly to the dose from the waste packages. Besides ${ }^{137} \mathrm{Cs}$, the main gamma contributors are ${ }^{154} \mathrm{Eu},{ }^{60} \mathrm{Co}$, and ${ }^{125} \mathrm{Sb}$. These three radionuclides all have half-lives of less than 10 years and are most evident in the waste feed for Envelope B.

We found that increasing the cesium DF beyond 1,000 has no appreciable effect on the dose rate from packages from Envelopes A and C. Even for Envelope B, the effect of additional cesium removal becomes less evident because of the dose contributions from ${ }^{154} \mathrm{Eu},{ }^{60} \mathrm{Co}$, and ${ }^{125} \mathrm{Sb}$. These findings strongly support our conclusion that cesium removal alone will not make all the ILAW packages contact-handled.

Two other conclusions that can be made were based on findings by Savino (1998), (Appendix B). One conclusion is that the glass marble waste form provides less self-shielding than a monolithic waste form and therefore produces a higher dose rate for a fixed package waste loading. The other conclusion is that the waste package size has a negligible effect on the dose rate for the package sizes allowed by the privatization specification. 
HNF-2110 Rev 0

\subsection{REFERENCES}

Berry, J. B., 1997, Interface Control Document Between DOE and the PHMC - Phase 1

Privatization - Immobilized Low-Activity Waste Product, HNF-SP-1219 (ICD-15) Draft, Lockheed Martin Hanford Corporation, Richland, Washington.

Burbank, D. A, M. J. Klem, 1997, Analysis of Alternatives for Immobilized Low-Activity Waste Disposal, HNF-SD-TWR-AGA-004, Rev 1, SGN Eurisys Services Corporation, Richland, Washington.

Brown, N. R., 1996, DSI to R. M. Orme, Westinghouse Hanford Company, LLW Product Waste Loading Assumptions for the TWRS Process Flowsheet, dated April, 23.

DOE-RL 1996, TWRS Privatization Contract Awards, Contracts DE-RP06-96RL13308 and DERP06-96RL13309, dated September 25, 1996, U.S. Department of Energy-Richland Operations Office, Richland, Washington.

Eiholzer, C. R. 1995, Disposal Facility Data for the Interim Performance Assessment, WHC-SDWM-RPT-159, Rev 0, Westinghouse Hanford Company, Richland, Washington.

Esch, R. A., 1998, Electronic Mail to T. M. Hohl, AZ-101 and AZ-102 Results, February 13, 1998, Waste Management Federal Services of Hanford, Inc., Richland, Washington.

FDNW, 1997, Preliminary Safety Evaluation for Project W-465 Immobilized Low-Activity Waste Interim Storage Facility, HNF-SD-W465-PSE-001 Rev 0, Fluor Daniel Northwest Incorporated, Richland, Washington.

Holton, L. , 1997, DSI to N. R. Brown, U.S. Department of Energy-Richland Operations Office, AN-107 Activity and Dose Rate Distribution, dated October 15, 1997.

Jones, T. E., R. T. Winward, M. J. Kupfer, 1997a, Tank Characterization Report for Double Shell Tank 241-AN-106, WHC-SD-WM-ER-569, Rev 0A, Lockheed Martin Hanford Corporation, Richland, Washington.

Jones, T. E., R. T. Winward, M. J. Kupfer, 1997b, Tank Characterization Report for Double Shell Tank 241-AN-107, WHC-SD-WM-ER-600, Rev 0A, Lockheed Martin Hanford Corporation, Richland, Washington.

Jones, T. E., R. T. Winward, M. J. Kupfer, 1997c, Tank Characterization Report for Double Shell Tank 241-AW-101, WHC-SD-WM-ER-470, Rev 0A, Lockheed Martin Hanford Corporation, Richland, Washington. 
HNF-2110 Rev 0

Jones, T. E., R. T. Winward, M. J. Kupfer, 1997d, Tank Characterization Report for Double Shell Tank 241-SY-101, WHC-SD-WM-ER-409, Rev 0A, Lockheed Martin Hanford Corporation, Richland, Washington.

Jones, T. E., R. T. Winward, M. J. Kupfer, 1997e, Tank Characterization Report for Double Shell Tank 241-SY-103, WHC-SD-WM-ER-471, Rev 1A, Lockheed Martin Hanford Corporation, Richland, Washington.

Kirkbride, R. A., G. K. Allen, P. J. Certa, A. F. Manuel, R. M. Orme, L. W. Shelton, E. J. Slaathaug and R. S. Whitman (NHC), G. T. MacLean and D. L. Penwell (SESC), 1997, Tank. Waste Remediation System Operation and Utilization Plan, HNF-SD-WM-SP-012, Rev 0A, Numatec Hanford Corporation, Richland, Washington.

Mann, F. M. and P. D. Rittman (FDNW), J. A. Voogd (LMHC), N. K. Kline (LMSI), Y. Chen, C. R. Eiholzer and B. P. McGrail (PNNL), A. H. Lu, and G. F. Williamson (rtd.), N. R. Brown and P. E. LaMont (U.S. DOE-RL), 1997, Hanford Low-Level Tank Waste Interim Performance Assessment, HNF-EP-0884, Rev 1, Lockheed Martin Hanford Company, Richland, Washington.

Mitchell, D. E., 1995, Immobilized Low-Level Waste Disposal Options Configuration Study, WHC-SD-WM-TI-686, Rev 0, Westinghouse Hanford Company, Richland, Washington.

Orme, R. M. 1996, TWRS Privatization Process Technical Baseline, WHC-SD-WM-TI-174, Rev 0, Westinghouse Hanford Company, Richland, Washington..

Parrington, J. R., H. D. Knox, S. L. Breneman, E. M. Baum and F. Feiner, 1996, Nuclides and Isotopes, Fifteenth Edition, General Electric Company and KAPL, Inc.

Place, D. E., 1997a, Tank Characterization Report for Double Shell Tank 241-AZ-101, WHCSD-WM-ER-410, Rev 0A, SGN Eurisys Services Corporation, Richland, Washington.

Place, D. E., 1997b, Tank Characterization Report for Double Shell Tank 241-AZ-102, WHCSD-WM-ER-411, Rev 0B, SGN Eurisys Services Corporation, Richland, Washington.

Savino, A. V, 1998, ILAW Shielding Evaluation, EBU-RCAL-001, Rev 0, Waste Management Federal Services, Inc., Northwest Operations, Richland, Washington.

Shelton, L. W., 1997, Tank Characterization Report for Double Shell Tank 241-AN-102, WHCSD-WM-ER-545, Rev 1A, Lockheed Martin Hanford Corporation, Richland, Washington. 


\section{HNF-2110 Rev 0}

Shelton, L. W., B. C. Simpson, 1997a, Tank Characterization Report for Double Shell Tank 241$A N-103$, WHC-SD-WM-ER-702, Rev 0, Lockheed Martin Hanford Corporation, Richland, Washington.

Shelton, L. W., B. C. Simpson, 1997b, Tank Characterization Report for Double Shell Tank 241$A N-104$, WHC-SD-WM-ER-690, Rev 0, Lockheed Martin Hanford Corporation, Richland, Washington.

Shelton, L. W., B. C. Simpson, 1997c, Tank Characterization Report for Double Shell Tank 241 $A N-105$, WHC-SD-WM-ER-678, Rev 0B, Lockheed Martin Hanford Corporation, Richland, Washington. 
HNF-2110 Rev 0

\section{APPENDIX A \\ Radionuclide Source Terms for Base and Sensitivity Cases}


HNF-2110 Rev 0

This page intentionally left blank.

A-2 


\section{CONTENTS}

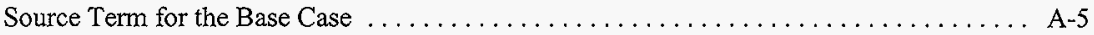

Source Term for Cesium Separation Efficiency, DF=210 (Envelopes A and C) . . . . . A A-6

Source Term for Cesium Separation Efficiency, DF=300 (Envelopes A and C) $\ldots \ldots \ldots$ A-7

Source Term for Cesium Separation Efficiency, DF=1,000 (Envelopes A, B and C) . . . . A A-8

Source Term for Waste Decayed to Feed Delivery Date by Batch $\ldots \ldots \ldots \ldots \ldots \ldots$ A-9

Source Term for Cesium DF=1,000 and Waste Decayed to Feed Delivery Date by Batch . A-10

Source Term for Low Waste Loading $\ldots \ldots \ldots \ldots \ldots \ldots \ldots \ldots \ldots \ldots \ldots \ldots \ldots \ldots \ldots \ldots \ldots$

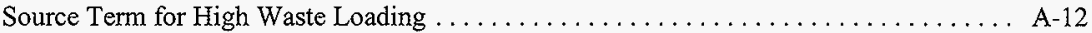

Source Term for Monolithic Waste Form Geometry ................... A-13 


\section{HNF-2110 Rev 0}

This page intentionally left blank.

A-4 


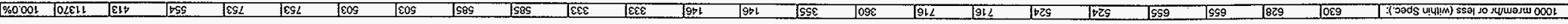

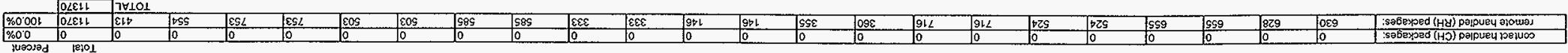

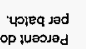

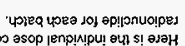

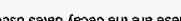

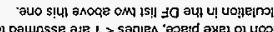

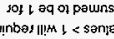

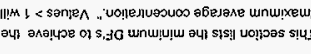

Tej 0 it

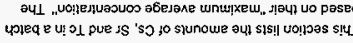

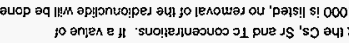

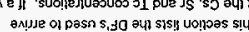

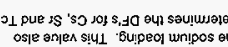

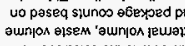

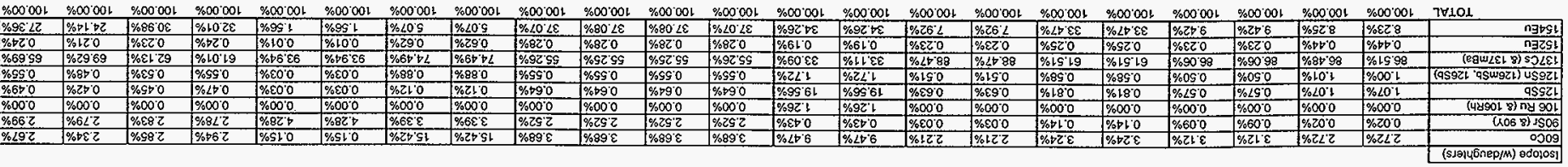

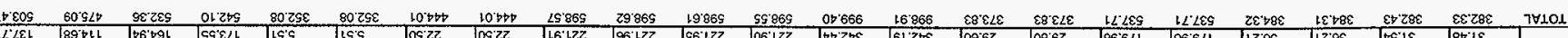

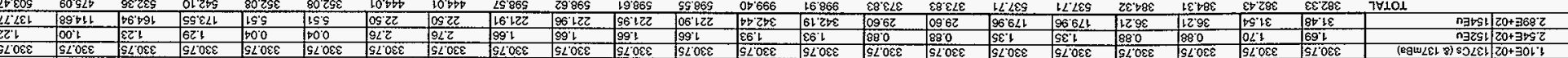

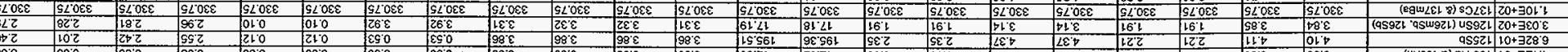

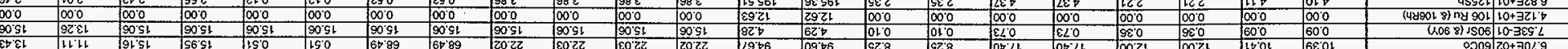

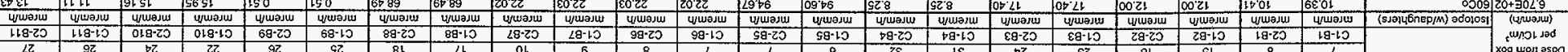

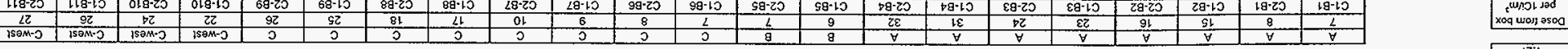

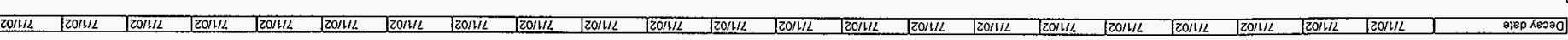

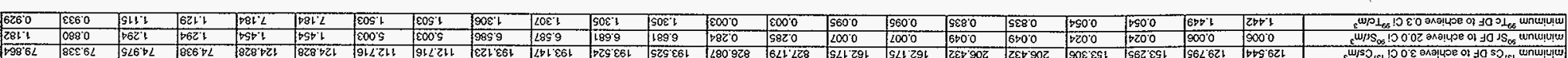

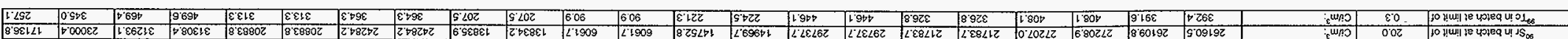

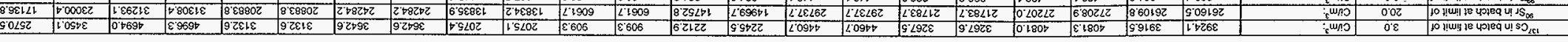

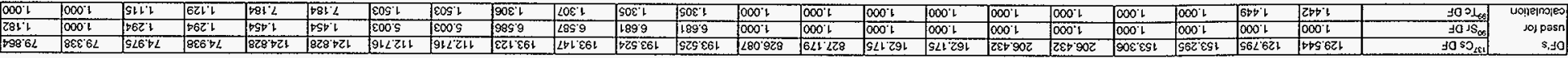

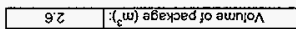

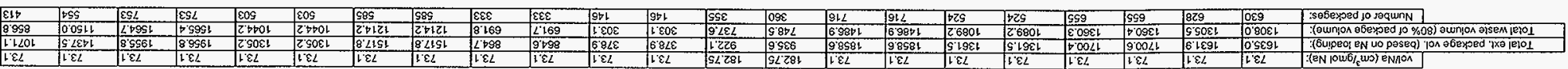

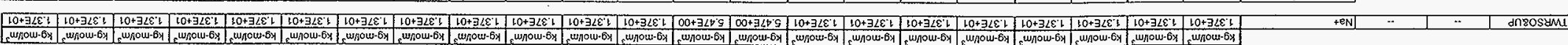

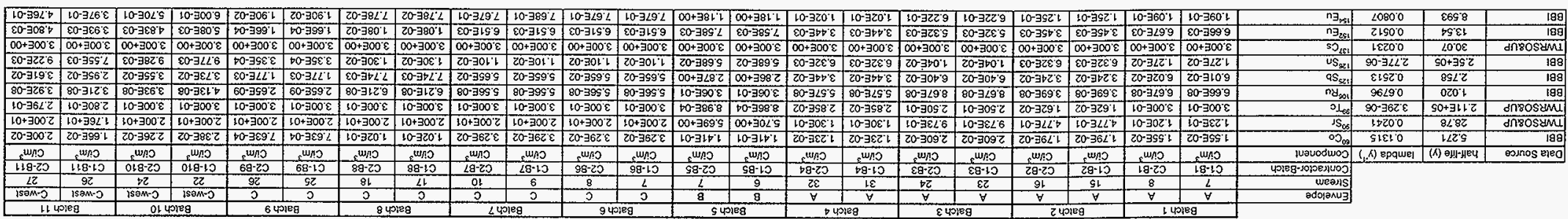

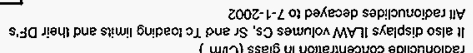

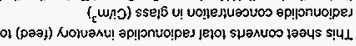


This shee: converts toial radionuclide inwontory (teed) to

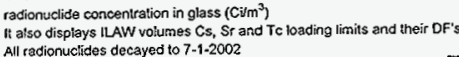

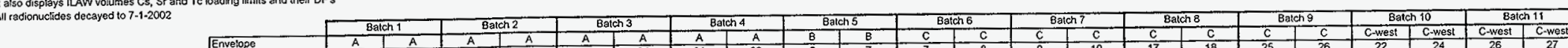

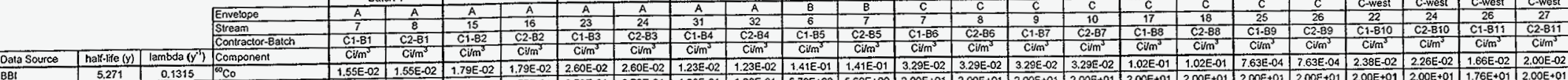

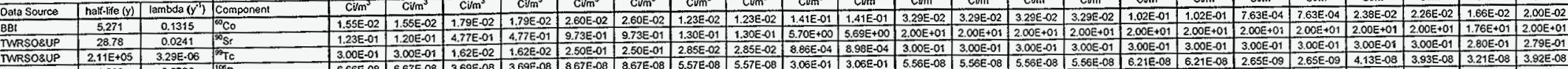

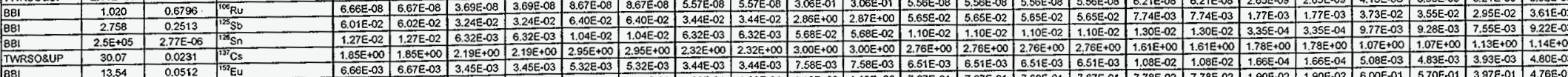

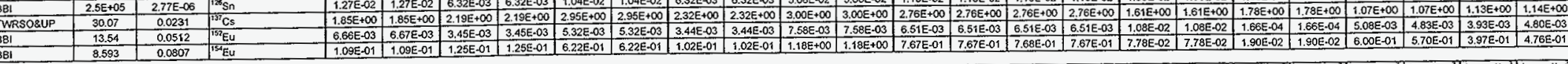

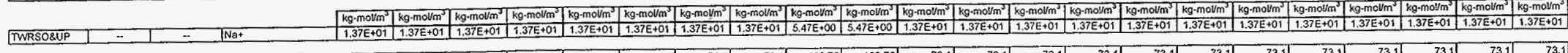

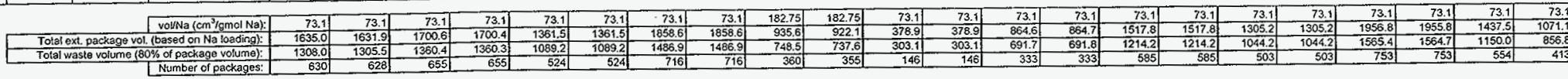
Volume of packaga o $\left(\mathrm{m}^{3}\right):=1$ 2.6

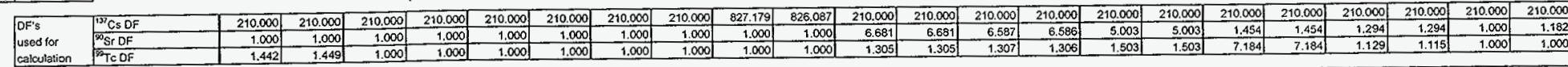

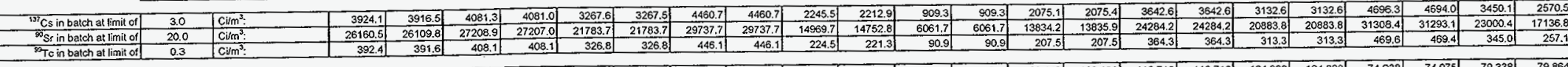

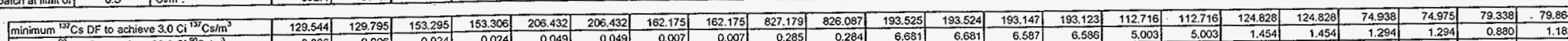

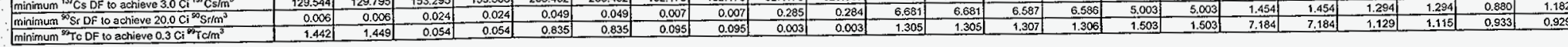

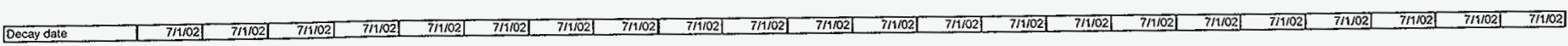
Wall Thickness (cm): $\quad 1.27$

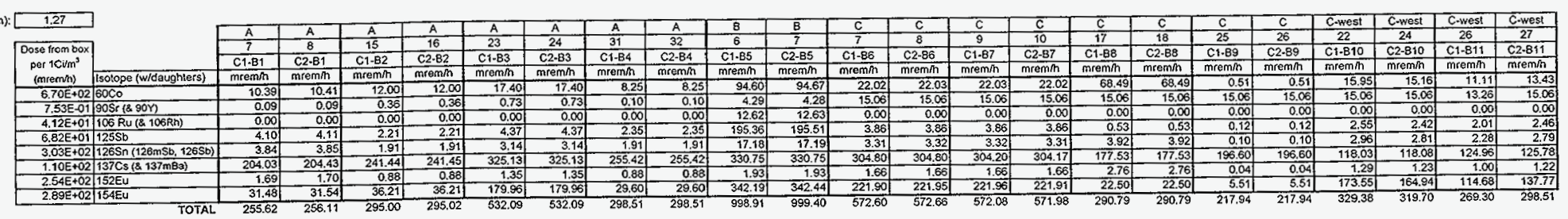

This sala is the catculation of d package c connts basodod on

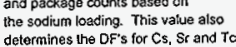

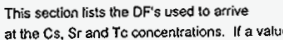

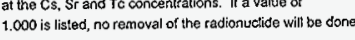
This section lists the amoun's of $C s$, St and $T c i n$ a batcos

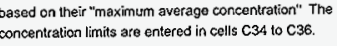

This section lists the minimum OF's to achieve the

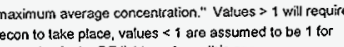

Thess are the vecay dalas used for each batich

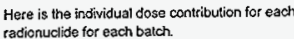

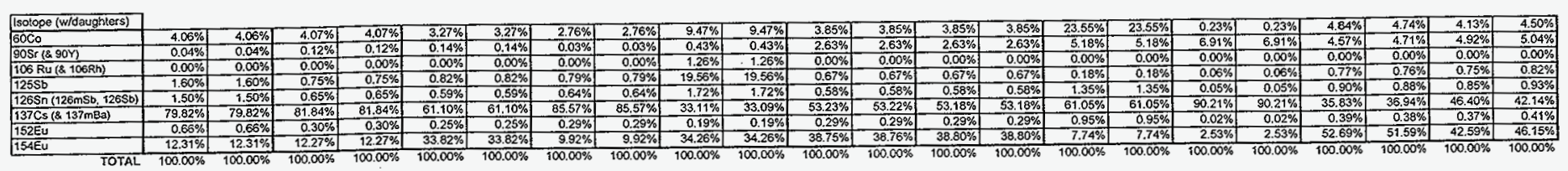

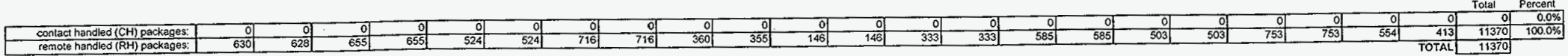

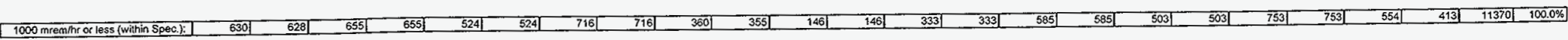




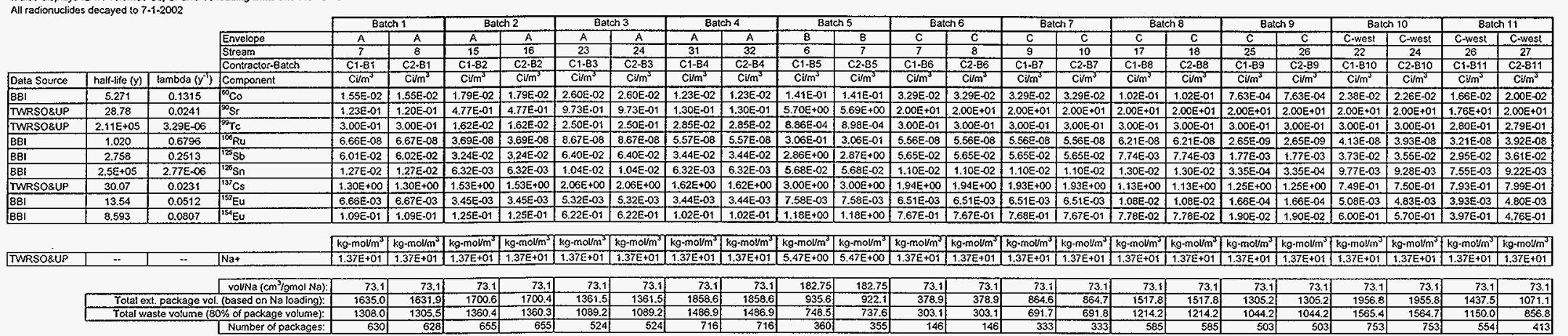

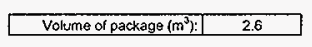

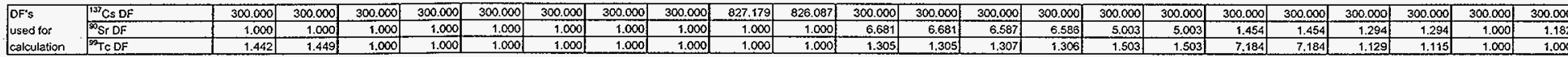

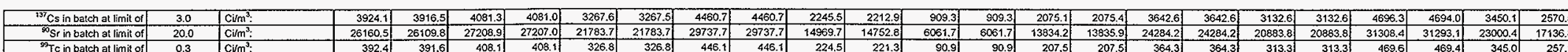

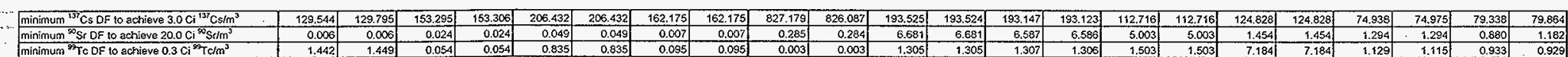
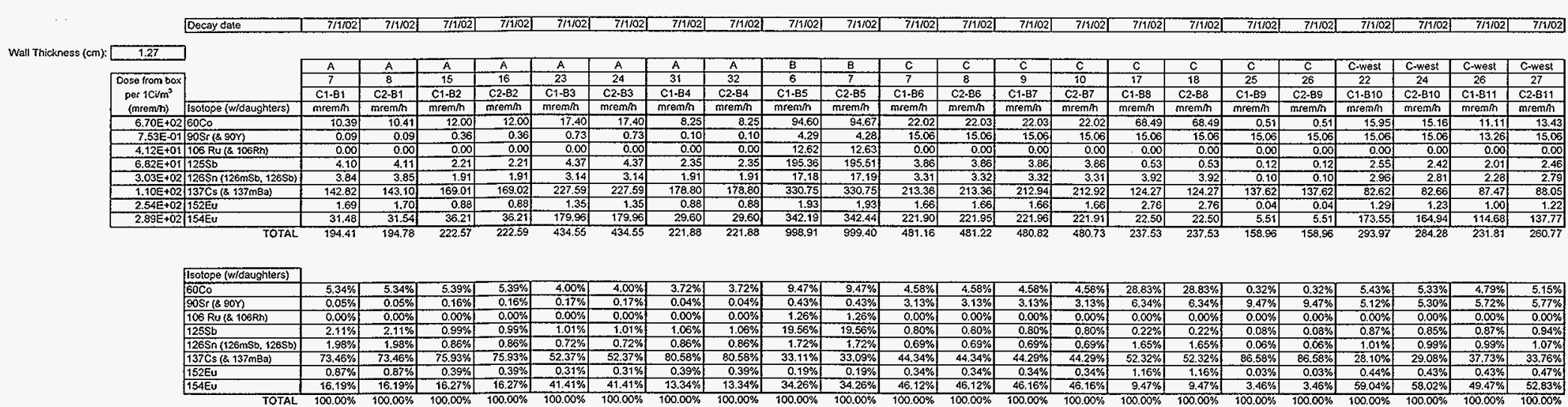

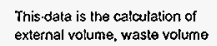

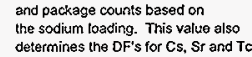

This section istst the DF's used to arrive

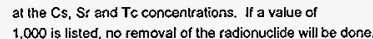
This section istst the amounits of $\mathrm{Cs}$, Srand Tein a batch based on their "Maximum average concentration" The
concentration Ininits ate entered in ceils c34 10 c 36 . Tris section ists the minimum OF's to achieve ine deceon to take place, values $<1$ aro assumes 10 be 1 tor
caculation These are the decay sales usod for each batich

Here is the inivividual doses concibution for each
radionuelilde for each batch.

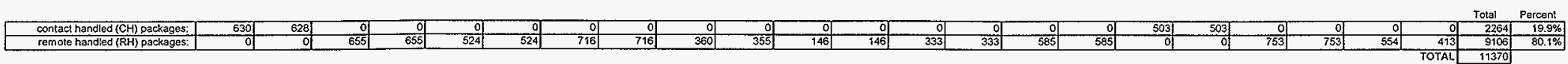

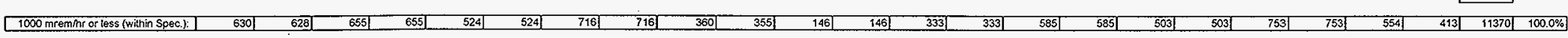


Find

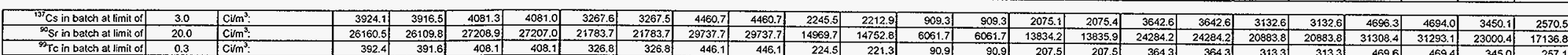

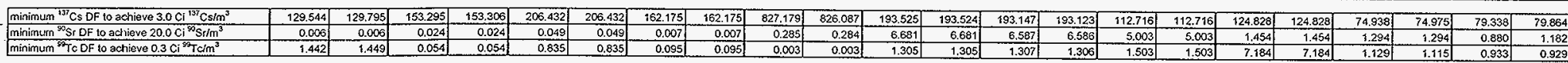
Wall Thickness (can):

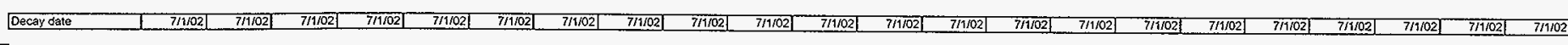

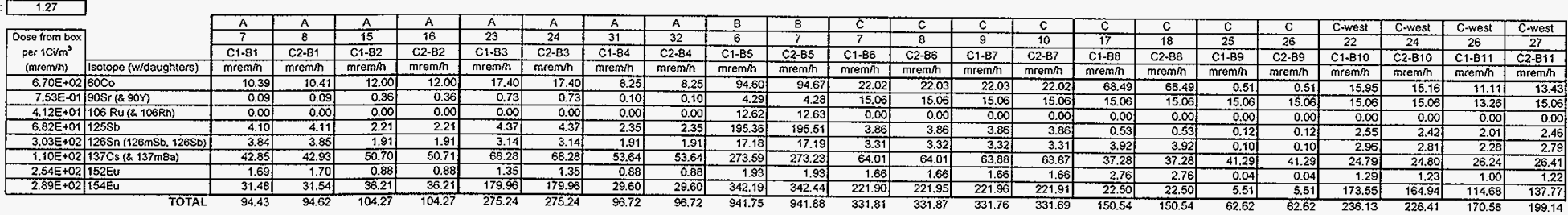

This data is the calculation of
external volume, waste volume and package counts based on
the sodium loading This value also
detereminines the DF's tor Cs, Sr and TC

mis section ifists the DF's used to arcive at the Cs, St and To concentrations. If a value of This section lists the amounts of Cs. Sr and Tc in a batch Jased on their "Maximum average concentration" The
concentration inits are enteredin cells 344 ioc 36 "

Thiis secion ists ine minimum DFs to cachiove the decon to take place, values $<1$ are assumed to be 1 for

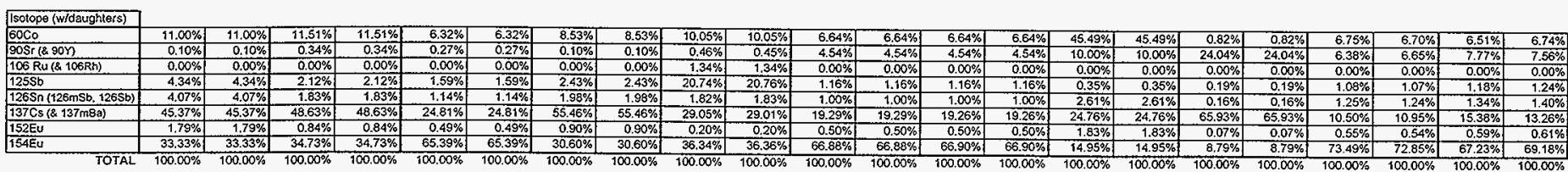

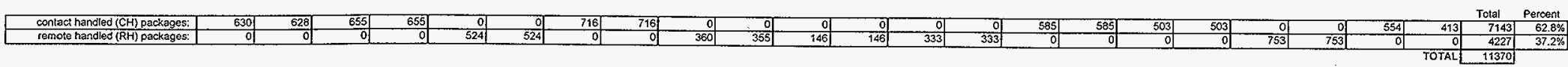

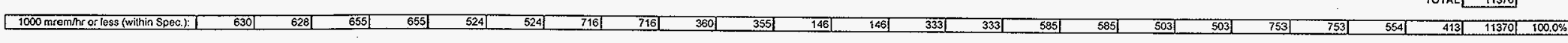




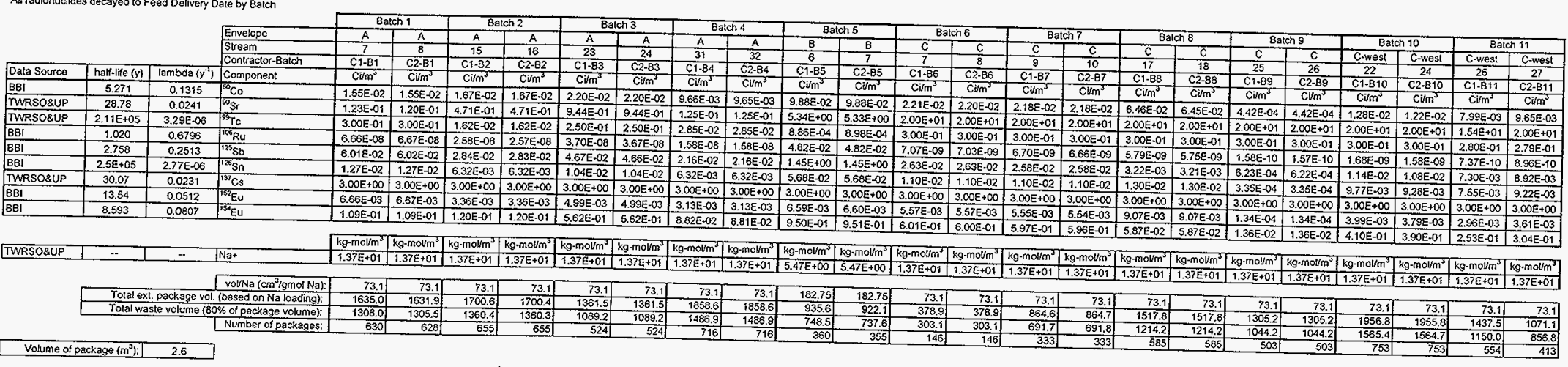

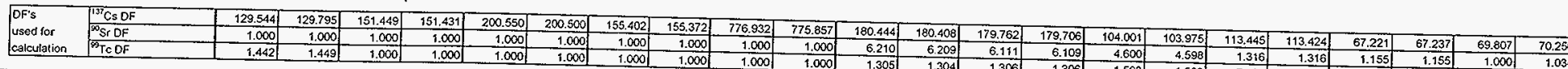

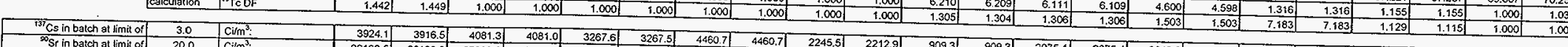

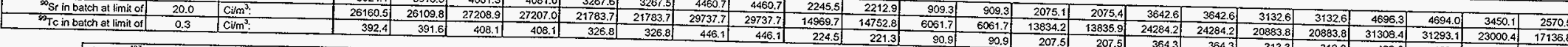

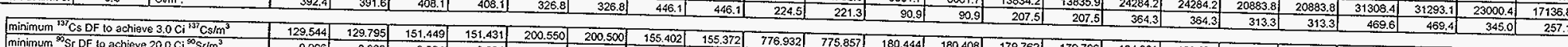

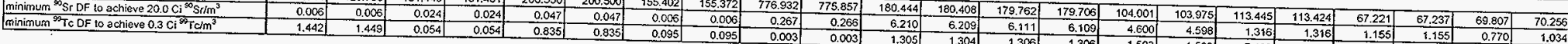
Wall Thickness

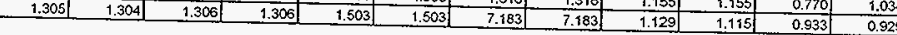
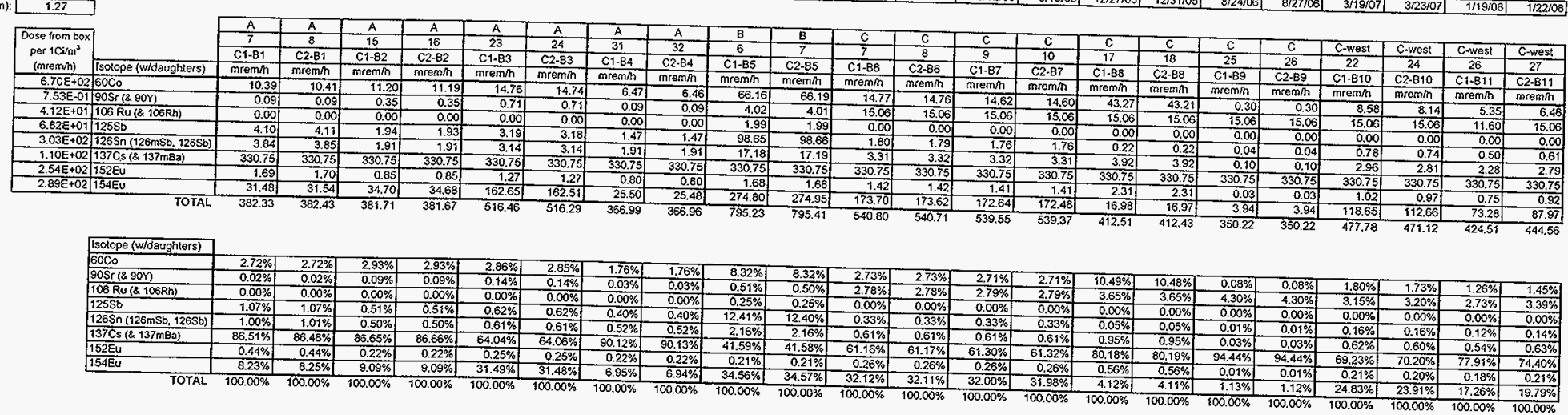

This data is the calculation of
exterinat volume, vaste volume

external volume, wasto volum
and packege counts sased on the sociuiug loading This value elso
determines the DF's for Cs, Sr and TT

This section lists the DF's used to arrive

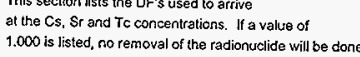
This section lists the amounts of CS. Sr and Tci in a batch based on thin "maximum average concentration" The
concentration inits arc entered in cells 034 lo $C 36$.

This section Ists the minimum DF's to achieve the maximum average concentration. "Vatuos $>1$ will require
decon to take place, values $<1$ are assumed to be 1 for These are the decay dos

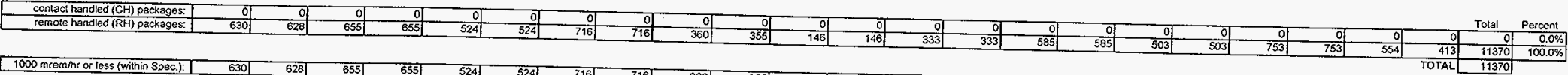

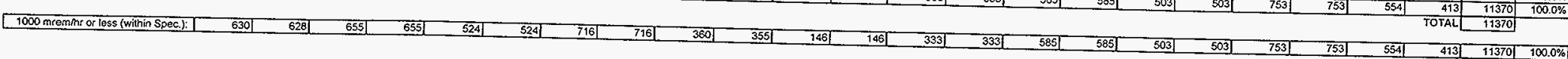


This sheet converts total radiontrectide inventior (feced) to

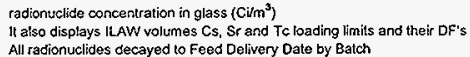

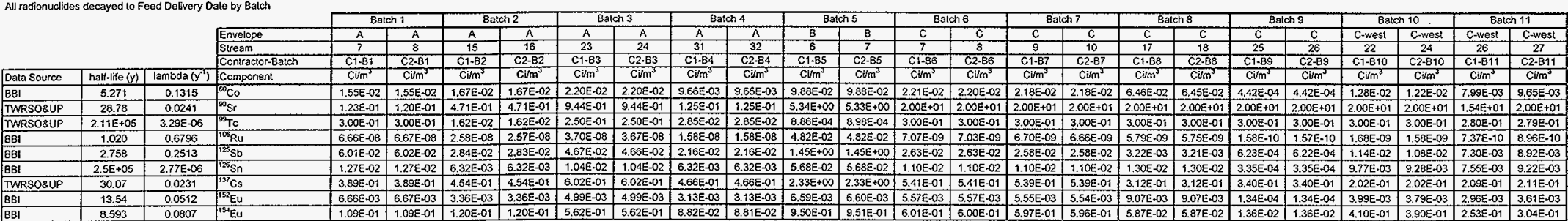

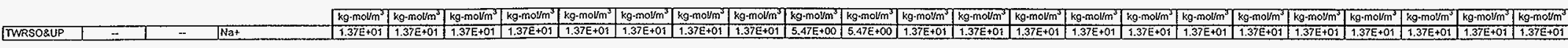

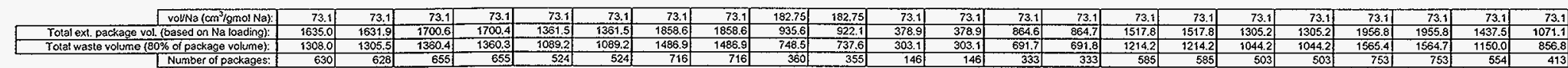
Volume of packege (m) $\left(m^{3}\right): 2.6$

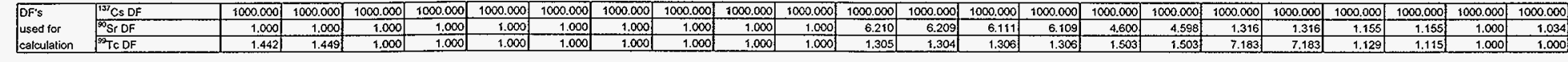

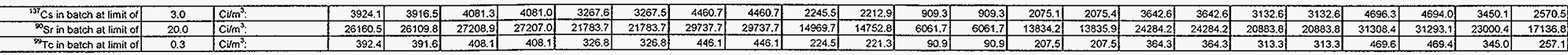

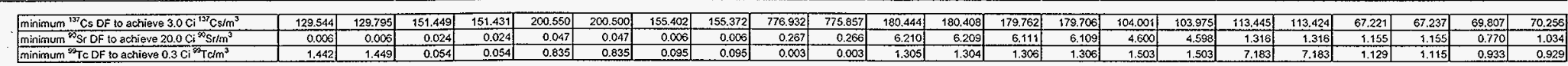

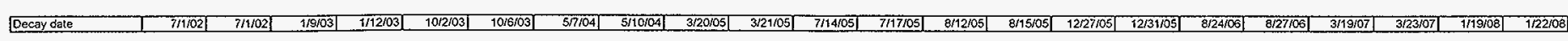
Wall Thickness $(\mathrm{cm}): \quad 1.27$

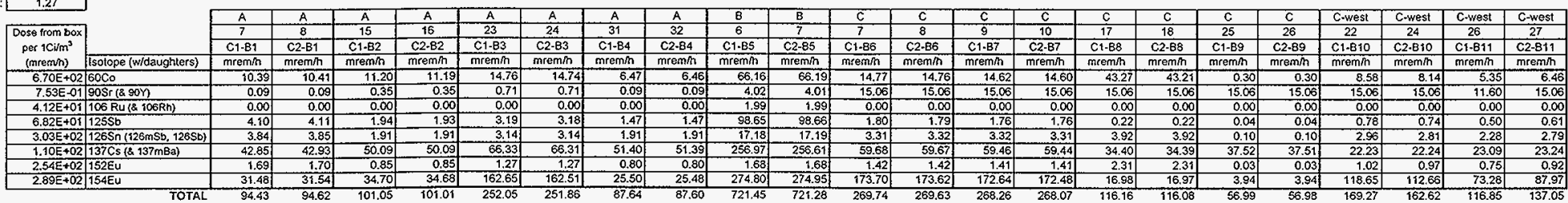

This data is the calculation of
external volume, waste volum

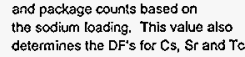

This section hists the DF's usod to arrive at ine Cs. Sr and Te concentrations. If a valuu of This section lisis the amounts of $\mathrm{CS}, \mathrm{St}$ and $\mathrm{Tc}$ in a baich concentration limits are eniered in colls $C 34$ to $\mathrm{C} 35$. This secion Iiss the minimum DF's 10 achieve the deccon to take pribes, values $<1$ are assumed to be 1 for calculation in the Of ist two above this one.

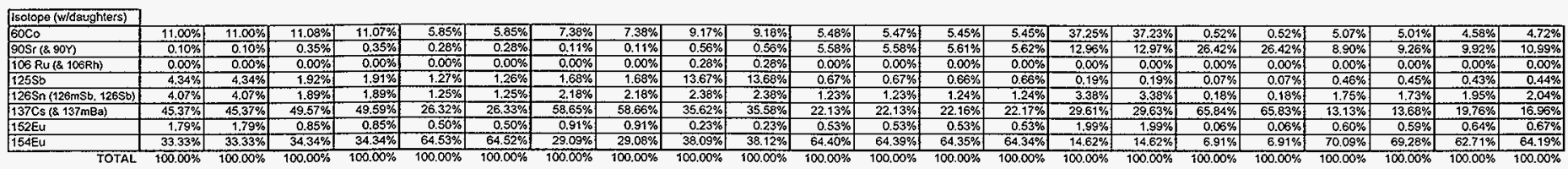

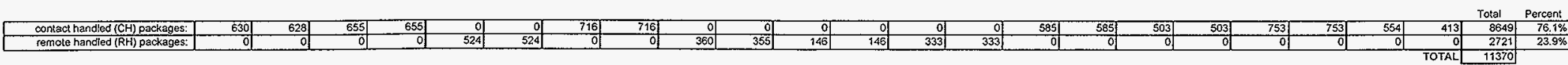

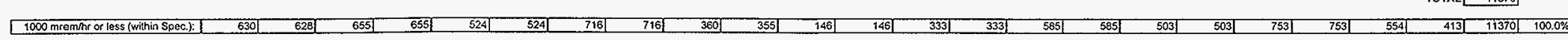




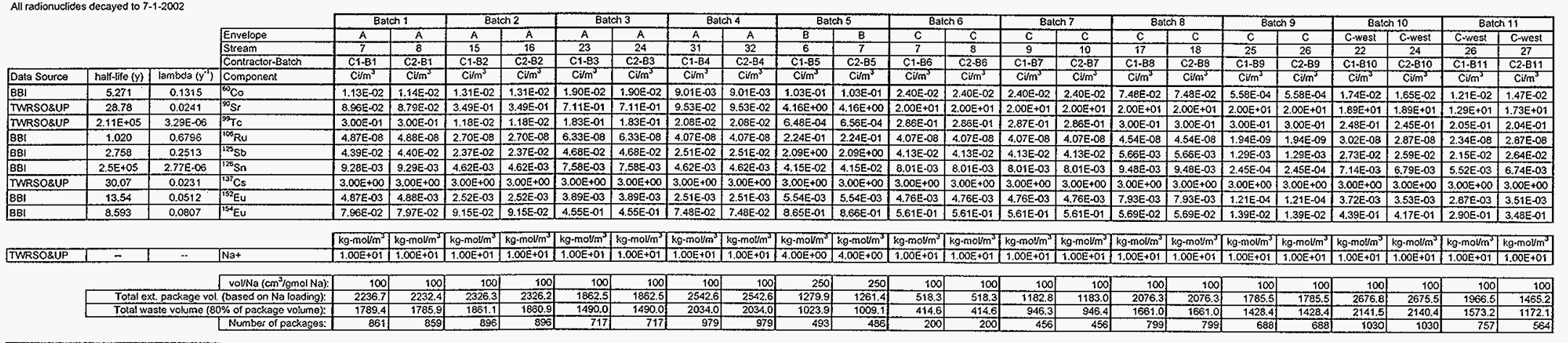
Volume of package $\left(\mathrm{m}^{3}\right):{ }_{2}$

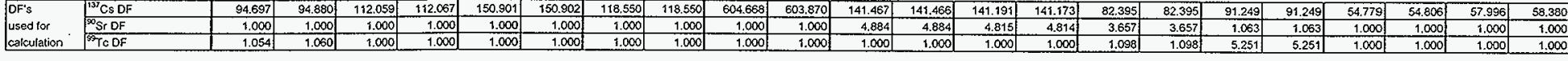

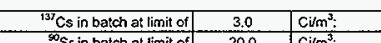

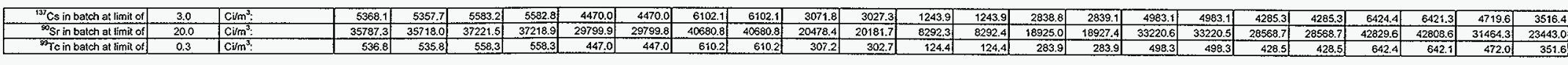

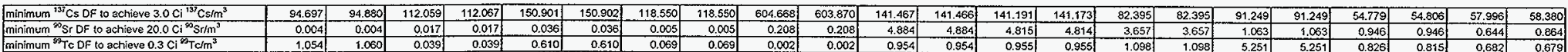

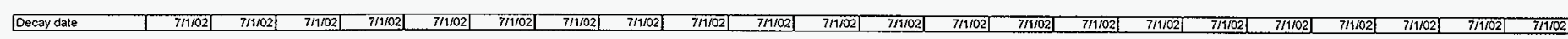
Wall Thickness (cm):
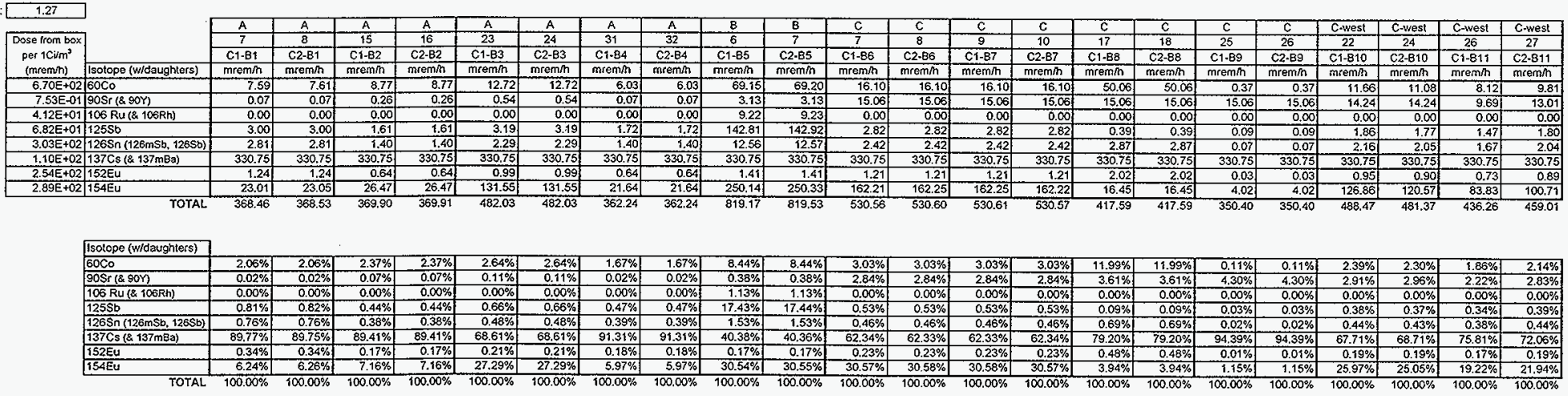

This data is the calculation of
extenal volume, waste volum

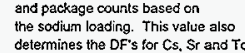

This section Iist the DF's used to arrive

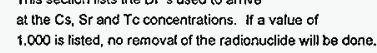
This section lists the amounts of CS. Sr and Tc in a batch based on their "maximum average concentration" The

This section lists the minimum DF''s to achieve the decon to to the phace values $<1$ are assumed to be 1 ior

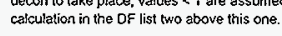

These are the decay dates used for each belkh

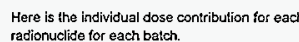

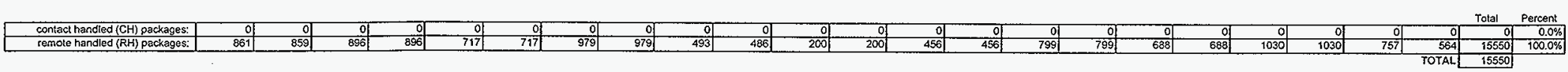

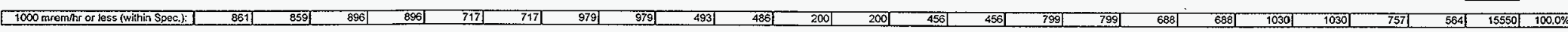




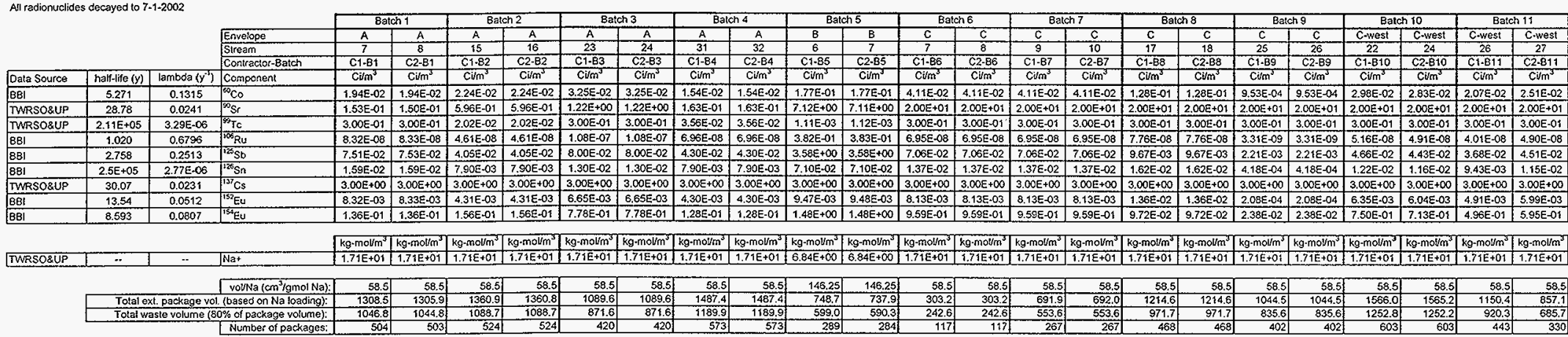
Volume of package $\left(m^{3}\right):-2.6$

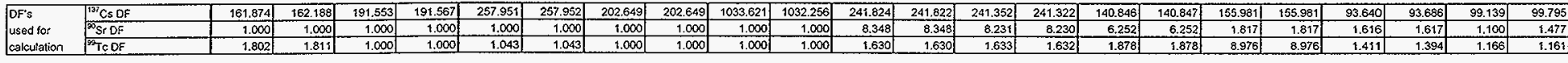

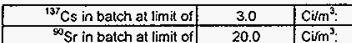

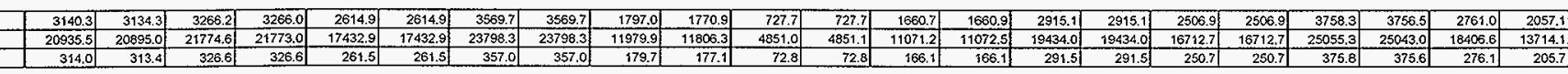

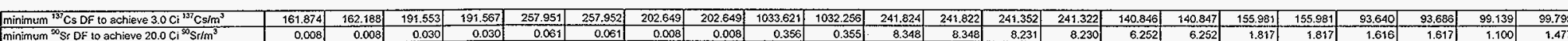

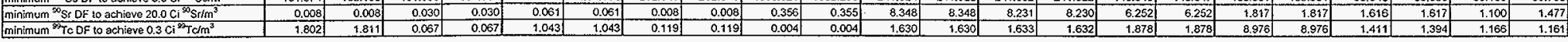

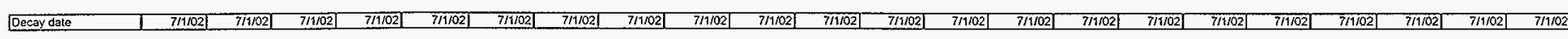
Wall Thickness (cm): $\quad 1.27$
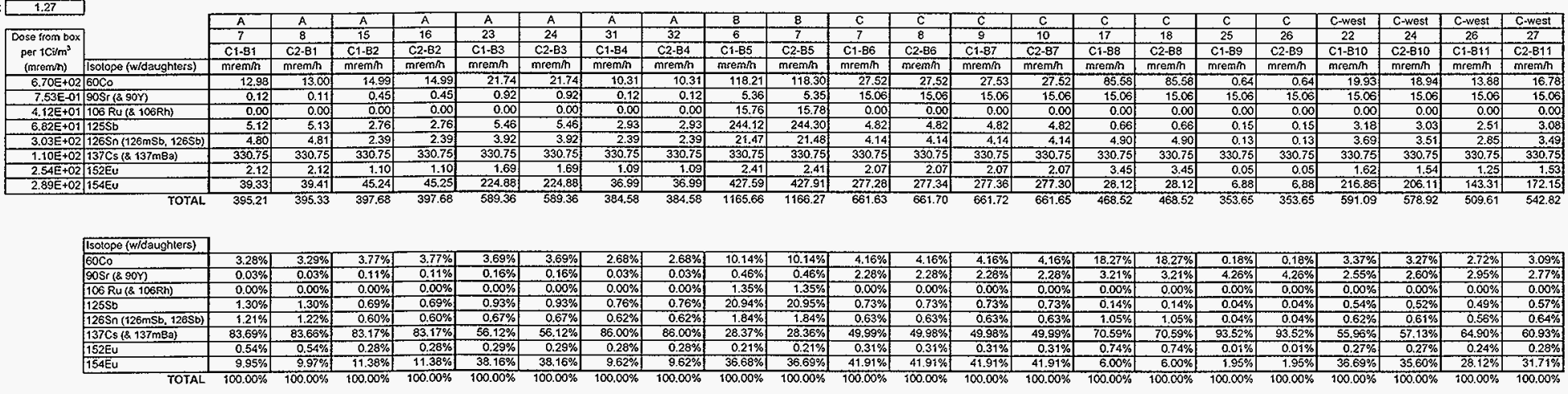

This data is the calculation of
external volume, waste volum and packago counts based on
the sodium loading This value also
determines the DF''s for Cs. Sr rand To

This seccion isists the DF's used to arrive

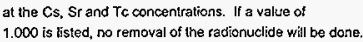
This section hists the amounis of Cs. St and Tc in a batch

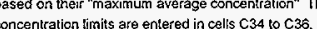

Mis seckion lists his minimum DF's to achleve the decon to take placo, values $<1$ are assumed 10 bo 1 lor These are tho decay dales used for each batc

Hore is the indivisual cosse contribution for each
radionuclide for each batch.

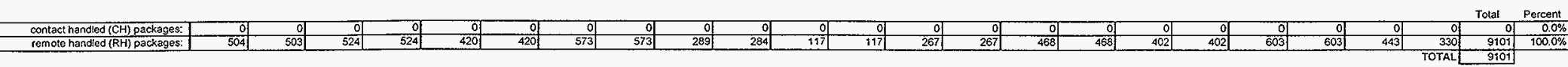

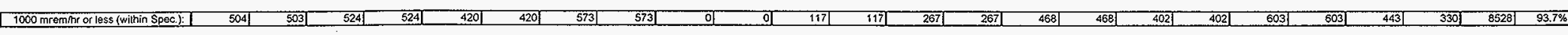


This sheet convents total radionvelide inventiory (feed) to

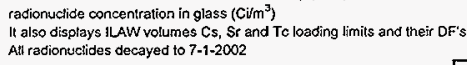

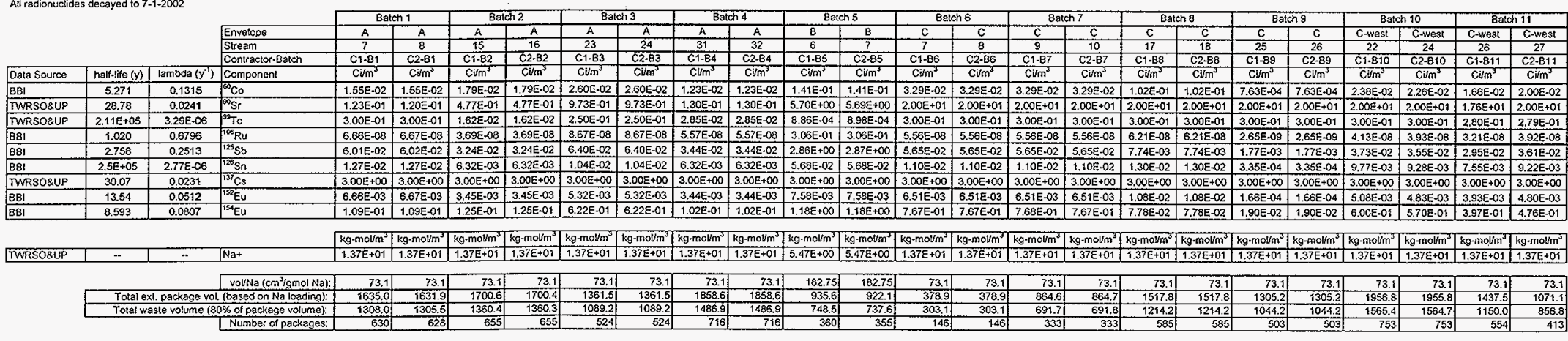
Volume of package $\left(\mathrm{m}^{3}\right): 2.6$

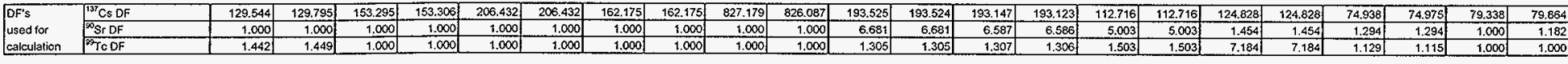

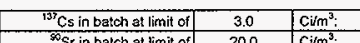

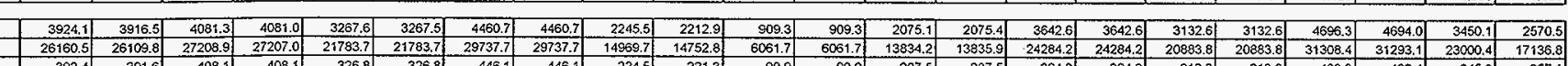

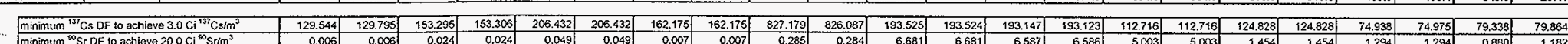

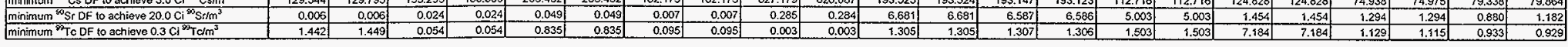

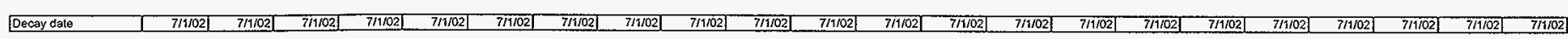
Wall Thleknoss (cm): $\quad 1.27$

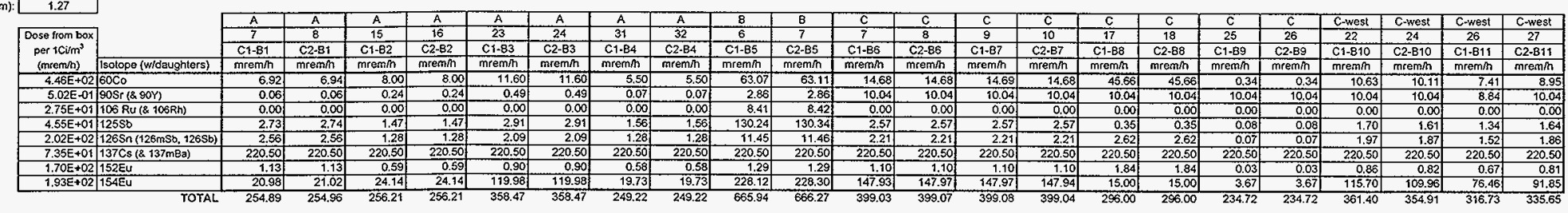

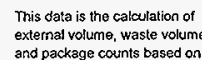

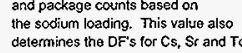

This section lists the DF's used to arrive

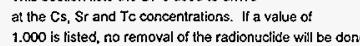
Yhis section lists the amounts of $C S$, Sr and To in a batch bassed on their "maximum averages concentration" This section ists the mininum OF's to achlove the docon to take place, values $<1$ are assumed 100 o 1 f for calculation in the of of list two a above this one.

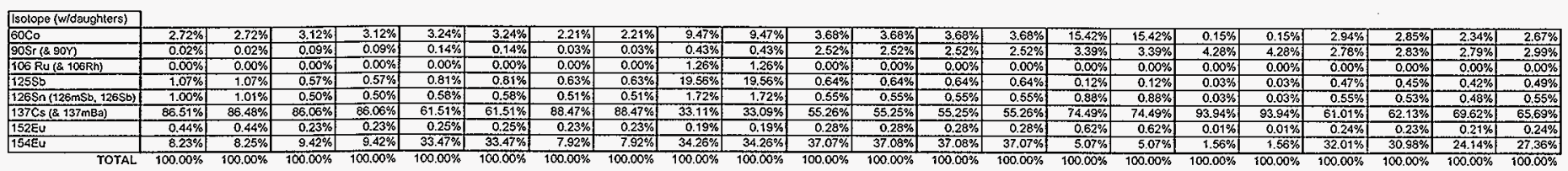

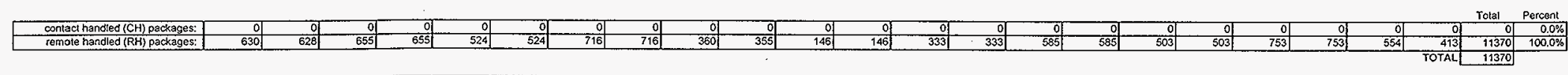

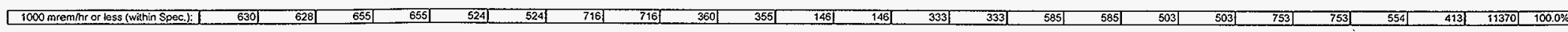


HNF-2110 Rev 0

\section{APPENDIX B ILAW Shielding Evaluation}


HNF-2110 Rev 0

This page intentionally left blank.

B-2 
HNF-2110 Rev 0

ENGINEERING ANALYSIS/DESIGN CALCULATION

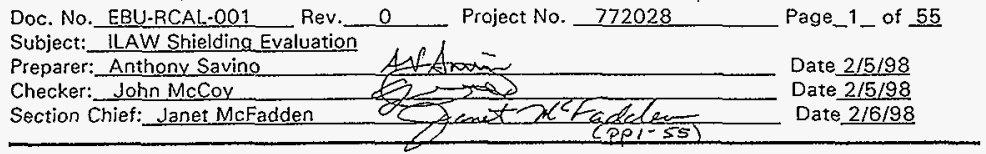

\subsection{INTRODUCTION AND SUMMARY}

Immobilized Low-Activity Waste (ILAW) produced from tank wastes by privatized treatment vendors will be stored and disposed in near surface facilities on the Hanford site. Product specifications for the ILAW allow radiation dose rates to be up to $1000 \mathrm{mR} / \mathrm{hr}$ on the surface of the package, which would require the waste packages to be handled remotely. Packages with dose rates below $200 \mathrm{mR} / \mathrm{hr}$ can be contact handled. In order to determine the number of contacthandled and remote-handled ILAW packages that would be expected, an operational source term is being developed by SESC. This source term will be used to calculate the expected radiation dose rates from the ILAW packages produced in Phase $1 \mathrm{~B}$ of the privatization contract period.

Twenty-two discrete feed batches will be delivered to the private vendors. The feed batches will result in product batches with varying source terms. In order to determine the radiation exposures from the various product batches, an analysis of shielding and dose rates is required. Sensitivity cases will also be developed to determine the effect of changes in key parameters (i.e., waste density, geometry) on the dose rates. A general analysis of dose rates as a function of package wall thickness and radionuclide concentration will allow the calculation of package dose rates for all of the cases.

SESC provided radioactive inventory data for the tanks involved in Phase 1 of the privatization program. Section 2 of this report documents the evaluation performed on the tank radioactive inventory data to determine which isotopes are key contributors to the direct dose outside the package. A criteria of $0.1 \%$ of the total dose was used to screen out unimportant isotopes, i.e., isotopes contributing greater than $0.1 \%$ to the total direct dose were considered key contributors, and were analyzed in Section 3.

Section 3 contains the results of the evaluation of dose rates as a function of package wall thickness for the isotopes considered key contributors. A second order polynomial fit of the $\log _{10}$ of the dose rate versus package wall thickness was performed for each of the key contributors. These equations provide a simple method to estimate the surface dose rate for each isotope for a given wall thickness, and can be used to estimate the number of $\mathrm{CH}$ and RH packages for that wall thickness. The dose rate versus wall thickness was found to be insensitive to the package size for the range of package sizes prescribed by the privatization contract. The dose rate versus wall thickness was found to be inversely proportional to the waste density. That is, the dose rates for a monolith $(100 \%$ glass density) was $2 / 3$ of the dose rate for glass marbles $(67 \%$ glass density).

Section 4 includes an evaluation of the neutron dose contribution to the total dose rate outside the package. The neutron dose rate was found to be less than $0.01 \%$ of the gamma dose rate, and therefore, does not need to be accounted for separately in the evaluation of the dose rates outside the package. 
HNF-2110 Rev 0

\section{ENGINEERING ANALYSIS/DESIGN CALCULATION}

Doc. No. EBU-RCAL-001 Rev. O Project No. 772028
Subject: ILAW Shielding Evaluation

\subsection{SELECTION OF KEY RADIONUCLIDES}

A spreadsheet containing tank waste radioactive inventory data for Phase 1 tanks was provided to WMNW by SESC. This spreadsheet is listed in Appendix A. This data was used to estimate the dose contribution from each isotope to determine which isotopes contributed greater than $0.1 \%$ to the total direct dose.

It was assumed that the relative amount of each isotope's activity in the ILAW was the same as that which exists in the tanks based on the tank inventory data from the spreadsheet. The only exception was for cesium where ion exchange columns will be used to reduce the cesium activity concentration by a factor of approximately 200 to meet the cesium activity concentration limit set forth in the privatization contract. For this analysis, a cesium reduction factor of 200 was selected and was agreed upon by SESC. Note that the final results, in terms of which radionuclides are important contributors to the direct dose, are not very sensitive to the assumed cesium reduction factor for a reasonable range of values.

The ORIGEN2 (Schmittroth 1995) computer code was used to calculate the time-dependent concentration of the isotopes present in the tank waste for a 50 year decay time. Table 1 lists the total initial radioactive inventory of each isotope for all of the Phase 1 tanks, as well as the inventory at decay times of 10 years and 50 years. Note that the inventory at 0 years is actually for a 1 day decay time to build in equilibrium daughter products. These activity values were used as input to the ILAW waste package shielding model after application of a reduction factor of 200 for the cesium isotopes (Cs134, Cs137).

The ISO-PC Version 2.1 computer program (Rittmann 1995) was used for all of the gammaray dose rate calculations in this report. ISO-PC uses the point-kernel integration method to compute the dose rate at a detector location. Bremsstrahlung photons are accounted for in the dose rate calculations. Fluence-to-dose conversion factors were based on anterior-to-posterior irradiation pattern (ANSI/ANS 1991). The shielding attenuation properties for the bulk materials used in the analysis were obtained from the ISO-PC data library. Note that ISO-PC Version 2.1 has not gone through the verification and vatidation (V\&V) process required by the WMNW Quality Assurance Program at this time. Appendix F contains a justification for use of ISO-PC Version 2.1 for the applications in this report.

A nominal configuration of the ILAW waste package was modeled using the ISO-PC computer code. The nominal configuration consisted of a waste package in the form of a rectangular steel box $1.2 \mathrm{~m}$ tall $\times 1.2 \mathrm{~m}$ wide $\times 1.8 \mathrm{~m}$ long, with a total wall thickness of $8 \mathrm{~cm}$ of steel for the waste package and shipping container. The ILAW waste form was assumed to be glass marbles consisting of $67 \%$ glass and $33 \%$ air by volume. The ILAW waste composition was based on LD6-5510 waste glass previously analyzed by WMNW (Savino, 1997). Table 2 lists the glass composition from Savino (1997). A wall thickness of $8 \mathrm{~cm}$ was considered a reasonable estimate for the total wall thickness for the evaluation of key contributors to the dose. 
HNF-2110 Rev 0

\section{ENGINEERING ANALYSIS/DESIGN CALCULATION}

\begin{tabular}{|c|c|c|}
\hline Doc. No. EBU-RCAL-001 Rev._. 0 & Project No. $\quad 772028$ & Page_3_ of 55 \\
\hline $\begin{array}{l}\text { Subject: } \text { ILAW Shielding Evaluation } \\
\text { Preparer: Anthony Savino }\end{array}$ & $A N$ & Date_2/5/98 \\
\hline Checker: John McCoy & & Date $2 / 5 / 98$ \\
\hline Section Chief: Janet McFadden & & Date 2/6/98 \\
\hline
\end{tabular}

The relative contribution of each isotope to the total dose was evaluated at these three time periods 10,10 , and 50 years) to identify which isotopes contributed greater than $0.1 \%$ to the total dose. The relative contributions were obtained by manipulating the ISO-PC output data. The aging waste tanks (AZ-101, AZ-102) were also evaluated separately as a special case due to the unique nature of the waste in these tanks. The same process described above was followed for Tank AZ101 waste using the tank-specific radioactive inventory in Appendix A. The radioactive waste composition of Tanks $A Z-101$ and $A Z-102$ are similar enough that only one of the two tanks reeds to be evaluated to determine which radionuclides are important from a direct-dose standpoint. Table 1 lists the Tank AZ-101 inventory at decay times of 0,10 , and 50 years. The ORIGEN2 input files for both cases are included in Appendix $B$. The ISO-PC input files for the initial inventory for the all Phase 1 tanks case and the AZ-101 case are included in Appendix $C$. Note that some isotopes present in the waste are not included in the 1SO-PC data library, however, these isotopes are unimportant from a direct-dose stanopoint.

Table 3 lists the approximate dose contributions for each isotope as calculated by the ISOPC computer code. From this table it is found that the following 10 isotopes contributed greater than $0.1 \%$ to the total direct dose:

Co60, Y90, Rh106, Sb125, Sb126m, Sb126, Cs134, Ba137m, Eu152, Eu154

Note that several of these isotopes are daughter products, as shown below, along with the parent-to-daughter branching ratio:

\begin{tabular}{|c|c|c|c|}
\hline Parent & Daughter & Branching & Ratiol \\
\hline $\mathrm{Sr} 90 \rightarrow$ & Y90 & $(1.0)$ & \\
\hline Ru $106 \rightarrow$ & Rh 108 & $\{1.0\}$ & \\
\hline $\mathrm{Sn} 126 \rightarrow$ & $\mathrm{Sb} 126 \mathrm{~m}$ & $(1.0) \rightarrow$ & Sb126 (0.14) \\
\hline $\mathrm{Cs} 137 \rightarrow$ & $8 a 137 m$ & $(0.946)$ & \\
\hline
\end{tabular}

In summary, the following isotopes are selected for further evaluation in this report: Co60, Sr90/Y90, Ru106/Rh106, Sb125, Sn126/Sb126m/Sb126, Cs134, Cs137/Ba137m, Eu152, and Eu154. Section 3.0 contains the calculations to determine the dose rate for each of these isotopes for an activity loading of $1 \mathrm{Ci} / \mathrm{m}^{3}$, and for steel wall thickness up to $20 \mathrm{~cm}$. Note that the results will be reported in terms of total dose rate in rem $/ \mathrm{h}$ per $\mathrm{Ci} / \mathrm{m}^{3}$ activity concentration of the parent isotope. For example, Y90 is in transient equilibrium with it's parent isotope Sr90; i.e., the activity of $Y 90$ is equal to the activity of $\mathrm{Sr} 90$. Therefore, the results will be reported in terms of rem/h per $\mathrm{Ci} / \mathrm{m}^{3}$ of $\mathrm{Sr} 90$; however, the dose rate will include the contributions from $1 \mathrm{Ci} / \mathrm{m}^{3}$ of both $\mathrm{Sr} 90$ and Y90. Similarly, the results for Ru 106 will include $1 \mathrm{Ci} / \mathrm{m}^{3}$ of both Ru 106 and $\mathrm{Rh} 106$, and $\mathrm{Cs} 137$ will include $1 \mathrm{Ci} / \mathrm{m}^{3}$ of $\mathrm{Cs} 137$ and $0.946 \mathrm{Ci} / \mathrm{m}^{3}$ Ba $137 \mathrm{~m}$. Finally, the results for $\mathrm{Sn} 126$ will include $1 \mathrm{Ci} / \mathrm{m}^{3}$ of $\mathrm{Sn} 126$ and $\mathrm{Sb} 126 \mathrm{~m}$, and $0.14 \mathrm{Ci} / \mathrm{m}^{3}$ of $\mathrm{Sb} 126$. 
HNF-2110 Rev 0

\section{ENGINEERING ANALYSISIDESIGN CALCULATION}

Doc. No. EBU-RCAL-001 Rev. 0
Subject: ILAW Shieldina Evaluation
Preparer: Anthony Savino Project No. 772028
Checker: $\frac{\text { John McCoy }}{\text { Soction Chief: Janet McFadden }}$

\section{O DOSE RATE CALCULATIONS VERSUS WALL THICKNESS.}

The base ISO-PC model discussed in Section 2.0 was used for all of the calculations in this section. The model consisted of a waste package in the form of a rectangular steel box $1.2 \mathrm{~m}$ tall $\times$. $1.2 \mathrm{~m}$ wide $\times 1.8 \mathrm{~m}$ long, with waste in the form of glass marbles consisting of $67 \%$ glass and $33 \%$ air by volume. Dose rates were calculated at the package surface, which is typicafly taken to be $1 \mathrm{~cm}$ from the outside of the package. The first wall thickness analyzed was $1 \mathrm{~cm}$, with the remaining thicknesses increasing from $2 \mathrm{~cm}$ to $20 \mathrm{~cm}$ in $2 \mathrm{~cm}$ increments. The package wall was modeled as iron with a density of $7.86 \mathrm{~g} / \mathrm{cc}$.

Table 4 contains the dose rate results for each isotope. Figures 1 and 2 display the results on a semi-log plot of dose rate versus wall thickness. These plots indicate that the $\log _{10}$ of the dose rate varies nearly linearly as a function of wall thickness. A linear regression was performed on the $\log _{10}$ of the dose rate versus the wall thickness for each isotope and it was found that for all but a few isotopes the fit resulted in errors less than $10 \%$. However, since some errors were as large as $30 \%$, a polynomial regression fit was performed for all isotopes. A second order polynomial fit markedly improved the results for those isotopes with larger fitting errors; therefore, a second order polynomial fit will be used for all isotopes for the final results reported herein.

The basic formula for calculating the dose rate using the polynomial fit is:

$$
\text { Dose Rate }(\mathrm{rem} / \mathrm{h})=10^{\left(a t^{2}+\mathrm{bt}+\mathrm{c}\right)}
$$

where, $a, b$, and $c$ are the fitting coefficients and $t$ is the steel wall thickness in $\mathrm{cm}$.

The polynomial fits resulted in fitting errors of less than $5 \%$ for all isotopes except Sr 90 which hạd errors of $12 \%$ and $10.3 \%$ for $1 \mathrm{~cm}$ and $4 \mathrm{~cm}$ thicknesses, respectively. Table 5 lists the fitting coefficients for each isotope. Appendix D contains example ISO-PC input files for Sr90/Y9O and $\mathrm{Sn} 126 / \mathrm{Sb} 126 \mathrm{~m} / \mathrm{Sb} 126$. Appendix $\mathrm{E}$ contains the output from a spreadsheet showing the percent differences between the calculated dose rates and the fitted values using the polynomial regression.

\subsection{SENSITIVITY CASES}

Two sensitivity cases were performed for $\mathrm{Cs} 137 / \mathrm{Ba} 137 \mathrm{~m}$. The first case is on package size, with the goal of examining the effect of increasing the package to $1.4 \mathrm{~m} \times 1.4 \mathrm{~m} \times 2.0 \mathrm{~m}$. The second case examines the effect of using a monolithic waste form consisting of $100 \%$ glass by volume.

The 1SO-PC cases for Cs137/Ba137m were rerun with the larger package size. The change in dose rate versus package wall thickness was found to be negligible when increasing the package size from $1.2 \mathrm{~m} \times 1.2 \mathrm{~m} \times 1.8 \mathrm{~m}$ to $1.4 \mathrm{~m} \times 1.4 \mathrm{~m} \times 2.0 \mathrm{~m}$ for 
HNF-2110 Rev 0

\section{ENGINEERING ANALYSIS/DESIGN CALCULATION}

\begin{tabular}{|c|c|c|}
\hline \multicolumn{3}{|c|}{ Doc. No. EBU-RCAL-001 Rev. $0 \quad$ Project No. $772028 \quad$ Page 5 of 55} \\
\hline Subject: ILAW Shielding Evaluation & & \\
\hline Preparer: Anthony Savino & & Date 2/5/98 \\
\hline Checker: John McCoy & $2+3$ & Date $2 / 5 / 98$ \\
\hline Section Chief: Janet McFadden & & Date $2 / 6 / 98$ \\
\hline
\end{tabular}

Cs $137 / 8 a 137 \mathrm{~m}$. Similar results are obtained for the other isotopes of interest in this report. Therefore, the polynomial fits developed in Section 3.0 for a package size of $1.2 \mathrm{~m} \times 1.2 \mathrm{~m} \times 1.8 \mathrm{~m}$ are valid for a package size of $1.4 \mathrm{~m} \times 1.4 \mathrm{~m} \times 2.0 \mathrm{~m}$.

The dose rates are essentially reduced by a factor of $2 / 3$ when changing from a composition of $67 \%$ glass $133 \%$ air to $100 \%$ glass by volume. This is a result of the use of a glass density of $1.66 \mathrm{~g} / \mathrm{cc}$ for the glass marble case versus a glass density of $2.5 \mathrm{~g} / \mathrm{cc}$ for the glass monolith case. The dose rates outside the package are nearly proportional to the glass waste density for a fixed average activity loading $\left(\mathrm{Ci} / \mathrm{m}^{3}\right)$ inside the package. Note that the activity loading $\left(\mathrm{Ci} / \mathrm{m}^{3}\right)$ being discussed here is based on the total volume of the package, not the volume of the waste. That is, an activity loading of $1 \mathrm{Cl} / \mathrm{m}^{3}$ in the package is equal to an activity loading of $1.5 \mathrm{Ci} / \mathrm{m}^{3}$ in the glass waste matrix for the glass marbles case where the waste composition is $67 \%$ glass and $33 \%$ air by volume.

In summary, the dose rate as a function of wall thickness is relatively insensitive to the package size for the range of package sizes of interest in this report. The dose rates for a monolithic package are simply $2 / 3$ of the dose rates for waste in the form of glass marbles. Appendix D contains the ISO-PC files for the 2 sensitivity cases.

\subsection{EVALUATION OF THE NEUTRON DOSE CONTRIBUTION}

The neutron source term was calculated using the ORIGEN2 computer code. The neutron source rate [SITH] for the total Phase 1 tank radioactive inventory is $9.6 \mathrm{E}+07$ neutrons/s which includes contributions from spontaneous fission as well as (alpha,n) reactions. The (alpha,n) contribution was calculated assuming an oxide fuel. The concentration of fissile material is low, so neutron multiplication will also be low. The neutron dose rate was estimated using the methods described in Estimation of Neutron Dose Rates from Nuclides Waste Packages (Nelson 1996) and was found to be insignificant $(<0.01 \%)$ compared to the gamma dose rate, as shown below. Note that the output data from the ORIGEN2 run documented in Section 2 was used to obtain the total neutron source reported in this section.

Estimated Neutron Dose Rate $(\mathrm{rem} / \mathrm{h})=\begin{gathered}0.01 \times \mathrm{S}(\mathrm{T}) \cdot 0.01 \times 9.6 \mathrm{E} 7 \\ \mathrm{r}^{2}\end{gathered}$

where, $S(T)$ is the total neutron source rate (neutrons/s), and $r$ is the distance $(\mathrm{cm})$ from the center of the source to the detector. For the ILAW, which is in the shape of a rectangular box, $r$ was taken to be $60 \mathrm{~cm}$, which is the smallest distance from the center of the source to the edge of the box. The gamma dose rate for the total Phase 1 tank radioactive inventory is approximately 3.8 $E+06 \mathrm{rem} / \mathrm{h}$ from the ISO-PC case discussed in Section 2. The neutron dose contribution is approximately $0.007 \%$ of the gamma dose rate, which is 
HNF-2110 Rev 0

\section{ENGINEERING ANALYSISIDESIGN CALCULATION}

Doc. No. EBU-RCAL-001 Rev. 0
Subject: ILAW Shielding Evaluation
Preparer: Anthony Savino
Checker: John McCoy
Section Chief: Janet McFadden

insignificant, and therefore, does not need to be accounted for in the evaluation of the dose rates outside the package.

\subsection{CONCLUSIONS}

The ORIGEN2 computer code was used to determine the amount of each isotope present (including daughter products) in the Phase 1 tanks for decay times of 0 years, 10 years, and 50 years using the initial radioactive inventory data provided by SESC for Phase 1 tanks. Note that the inventory at $O$ years is actually for a 1 day decay time to build in equilibrium daughter products. Table 1 summarizes the radioactive inventory for these three time periods.

The ISO-PC computer code was used to determine which isotopes present in the tank waste were considered key contributors to the dose, i.e., which isotopes contributed greater than $0.1 \%$ to the total direct dose outside the package for the three time periods (see Table 3). The following isotopes were found to be key contributors: Co60, Sr90/90, Ru106/Rh106, Sb125, $\mathrm{Sn} 126 / \mathrm{Sb} 126 \mathrm{~m} / \mathrm{Sb} 126, \mathrm{Cs} 134, \mathrm{Cs} 137 / \mathrm{Ba} 137 \mathrm{~m}$, Eu152, and Eu154.

The dose rate versus wall thickness for an activity loading of $1 \mathrm{Ci} / \mathrm{m}^{3}$ was calculated for each of the key contributors using the ISO-PC computer code. Table 4 and Figures 1 and 2 present these results. A second order polynomial fit of the $\log _{10}$ of the dose rate versus package wall thickness was found to provide a reasonably accurate fit of the data, with fitting errors of less than $5 \%$ for all isotopes except $\mathrm{Sr} 90$ which had errors of $12 \%$ and $10.3 \%$ for $1 \mathrm{~cm}$ and $4 \mathrm{~cm}$ thicknesses (see Appendix E). Table 5 contains the polynomial regression fitțing coefficients for the key contributors.

The dose rate versus wall thickness was found to be insensitive to the package size for the range of package sizes prescribed by the privatization contract. The dose rate versus wall thickness was found to be inversely proportional to the waste density. That is, the dose rates for a monolith $(100 \%$ glass density) was $2 / 3$ of the dose rate for glass marbles $167 \%$ glass density).

The neutron dose rate was found to be less than $0.01 \%$ of the gamma dose rate, and therefore, does not need to be accounted for separately in the evaluation of the dose rates outside the package. 


\section{ENGINEERING ANALYSIS/DESIGN CALCULATION}

Doc. No. EBU-RCAL-001 Rev. 0 Project No. 772028
Subject: ILAW Shielding Evaluation
Preparer: Anthony Savino
Checker: John McCoy
Section Chief: Janet McFadden

\section{O REFERENCES}

ANSI/ANS, 1991, Neutron and Gamma-ray Fluence-to-dose Factors, ANSI/ANS-6.1.1-1991, American National Standards Institute/American Nuclear Society, New York, New York.

Nelson, J. V., 1996, Estimation of Neutron Dose Rates from Nuclear Waste Packages, (internal memo 8M730-JVN-96-007 to J. R. Green, March 8), Westinghouse Hanford Company, Richland, Washington.

Rittmann, P. D., 1995, ISO-PC Version 1.98 - User's Guide, WHC-SD-WM-UM-030, Rev. 0, Westinghouse Hanford Company, Richland, Washington.

Savino, A. V., 1997, Transmittal of Packaging Reports for Immobilized Low-Activity Waste Transport, WMNW-9756121, July 21, 1997, Waste Management Federal Services, Inc., Northwest Operations, Richland, Washington.

Schmittroth, F. A., 1994, Conversion of ORIGEN2 to Sun Workstations, WHC-SD-NR-SWD-006 Rev. 1, Westinghouse Hanford Company, Richland, Washington. 
HNF-2110 Rev 0

\section{ENGINEERING ANALYSIS/DESIGN CALCULATION}

Doc. No. EBU-RCAL-001 Rev. O
Subject: ILAW Shielding Evaluation
Preparer: Anthony Savino
Checker: John McCoy
Section Chief:_Janet McFadden

Table 1 Phase 1 Tanks Radioactive Inventory, $\mathrm{Ci}$

\begin{tabular}{|c|c|c|c|c|c|c|}
\hline \multirow{2}{*}{ Isotope } & \multicolumn{3}{|c|}{ Total for All Phase 1 Tanks } & \multicolumn{3}{|c|}{ Tank AZ-101 } \\
\hline & Initial & 10 yrs & 50 yrs & Initial & 10 yrs & 50 yrs \\
\hline H3 & $1.95 E+04$ & $1.11 E+04$ & $1.18 E+03$ & $4.00 E+00$ & $2.28 \mathrm{E}+00$ & $2.42 \mathrm{E}-01$ \\
\hline C 14 & $3.10 E+04$ & $3.10 E+04$ & $3.08 E+04$ & $4.30 E-01$ & 4.30E-01 & $4.28 \mathrm{E}-01$ \\
\hline N159 & $1,00 E+02$ & $1.00 E \div 02$ & $1.00 E+02$ & $1.99 E+01$ & $1.99 \mathrm{E}+07$ & $1.99 E+01$ \\
\hline $\mathrm{CO} 60$ & $9.63 E+03$ & $2.58 E+03$ & $1.34 \mathrm{E}+01$ & $4.61 E+03$ & $1.24 E \div 03$ & $6.42 \mathrm{E}+00$ \\
\hline Ni63 & $1.04 E+04$ & $9.635+03$ & $7.12 E \div 03$ & $2.30 \mathrm{E}+03$ & $2.14 E+03$ & $1.58 E+03$ \\
\hline SE79 & $1.71 E+02$ & $1.71 E+02$ & $1.71 E+02$ & $4.13 E+01$ & $4.13 E+01$ & $4.13 E+01$ \\
\hline SR9o & $5.12 E+08$ & $4.03 E+08$ & $1.56 E+08$ & $6.36 E+06$ & $5.02 E+06$ & $1.94 E+06$ \\
\hline Y 90 & $5.12 E+.08$ & $4.03 E+08$ & $1.56 E+08$ & $6.36 \mathrm{E}+06$ & $5.02 E+.0 S$ & $1.94 E \div 06$ \\
\hline ZR93 & $9.30 \mathrm{E}+02$ & $9.30 E+02$ & $9.30 E+02$ & $1.99 E+02$ & $1.99 E+02$ & $1.99 E+02$ \\
\hline N893M & $5.80 E \div 02$ & $7.01 E+02$ & $8.60 E+02$ & $8.75 E+01$ & $1.28 E+02$ & $1.81 E+02$ \\
\hline TCg9 & $2.12 E+04$ & $2.12 E+04$ & $2.12 E+04$ & $1.10 \varepsilon+03$ & $1.10 E+03$ & $1.10 E+03$ \\
\hline Ru106 & $1.82 E+05$ & $1.88 E+02$ & $2.15 E-10$ & $1.06 E \div 05$ & $1.09 E+02$ & $1.24 \mathrm{E}-10$ \\
\hline $\mathrm{RH} 106$ & $1.82 E+05$ & $1.88 \mathrm{E}+02$ & $2.15 E-10$ & $1.06 \mathrm{E}+05$ & $1.09 E+02$ & $1.25 \mathrm{E}-10$ \\
\hline CD113M & $6.62 E+03$ & $4.12 E+03$ & $6.16 \mathrm{E}+02$ & $2.12 E+03$ & $1.32 E+03$ & $1.97 E+02$ \\
\hline SB125 & $2.30 E+05$ & $1.89 E+04$ & 8.49E-01 & $1.31 E+05$ & $1.07 E+04$ & $4.83 \mathrm{E}-01$ \\
\hline TE $125 \mathrm{M}$ & $6.30 E+02$ & $4.61 E+03$ & 2.07E-01 & $3.58 E+02$ & $2.62 E+03$ & $1.18 \mathrm{E}-01$ \\
\hline SN126 & $2.94 \mathrm{E}+02$ & $2.94 \mathrm{E}+02$ & $2.93 E+02$ & $6.57 E+01$ & $6.57 E+01$ & $6.57 E+01$ \\
\hline SB126 & $2.23 E+00$ & $4.11 \mathrm{E}+01$ & $4.11 E+01$ & $5.01 \mathrm{E}-01$ & $9.20 \mathrm{E}+00$ & $9.20 E+00$ \\
\hline SB126M & $2.94 E+02$ & $2.94 \mathrm{E}+\mathrm{O} 2$ & $2.93 E+.02$ & $6.57 E \div 01$ & $6.57 E+01$ & $6.57 E+01$ \\
\hline 1129 & $3.83 E+01$ & $3.83 E+01$ & $3.83 E+01$ & $7.10 \mathrm{E}+00$ & $7.10 \mathrm{E}+00$ & $7.10 \varepsilon+00$ \\
\hline $\operatorname{Cs} 134$ & $8.55 E+04$ & $2.97 E+03$ & $4.29 E-03$ & $4.34 E+04$ & $1.51 E+03$ & $2.18 \mathrm{E}-03$ \\
\hline $\operatorname{CS} 137$ & $2.54 E+07$ & $2.02 E+07$ & $8.00 E+06$ & $7.43 E+06$ & $5.90 E+06$ & $2.34 E+06$ \\
\hline BA137M & $2.40 E+07$ & $1.91 E+07$ & $7.57 E+06$ & $7.03 E+06$ & $5.58 E+06$ & $2.22 E+06$ \\
\hline
\end{tabular}


HNF-2110 Rev 0

\section{ENGINEERING ANALYSIS/DESIGN CALCULATION}

Doc. No. EBU-RCAL-001 Rev. O Subject: LAW Shielding Evaluation Preparer: Anthony Savino Checker: John McCoy Section Chief: Janet McFadden Project No. $\mathbf{7 7 2 0 2 8}$ Page_9_ of $\underline{55}$

\begin{tabular}{|c|c|c|c|c|c|c|}
\hline \multirow{2}{*}{ Isotope } & \multicolumn{3}{|c}{ Total for All Phase 1 Tanks } & \multicolumn{3}{c|}{ Tank AZ-101 } \\
\cline { 2 - 7 } & Initial & 10 yrs & 50 yrs & Initial & 10 yrs & 50 yrs \\
\hline SM151 & $6.70 E+05$ & $6.20 E+05$ & $4.56 E+05$ & $1.42 E+05$ & $1.32 E+05$ & $9.67 E+04$ \\
\hline EU152 & $5.48 E+02$ & $3.29 E+02$ & $4.29 E+01$ & $2.73 E+02$ & $1.64 E+02$ & $2.14 E+01$ \\
\hline EU154 & $9.23 E+04$ & $4.12 E+04$ & $1.64 E+03$ & $5.76 E+04$ & $2.57 E+04$ & $1.02 E+03$ \\
\hline EU155 & $1.44 E+05$ & $3.56 E+04$ & $1.33 E+02$ & $7.15 E+04$ & $1.77 E+04$ & $6.60 E+01$ \\
\hline TL207 & $6.33 E-05$ & $6.61 E-02$ & $1.29 E-01$ & $1.86 E-06$ & $1.57 E-03$ & $2.69 E-03$ \\
\hline TL208 & $4.74 E-04$ & $1.35 E+01$ & $8.48 E+00$ & $5.43 E-09$ & $1.50 E-04$ & $1.05 E-04$ \\
\hline TL209 & $8.33 E-06$ & $8.09 E-03$ & $1.91 E-02$ & & & \\
\hline PB209 & $2.51 E-04$ & $3.75 E-01$ & $8.84 E-01$ & $1.22 E-09$ & $1.86 E-06$ & $1.27 E-05$ \\
\hline PB210 & $3.81 E-08$ & $1.46 E-03$ & $4.35 E-03$ & $1.25 E-09$ & $4.79 E-05$ & $1.42 E-04$ \\
\hline PB211 & $6.35 E-05$ & $6.63 E-02$ & $1.29 E-01$ & $1.87 E-06$ & $1.58 E-03$ & $2.70 E-03$ \\
\hline PB212 & $1.32 E-03$ & $3.75 E+01$ & $2.36 E+01$ & $1.51 E-08$ & $4.17 E-04$ & $2.92 E-04$ \\
\hline PB214 & $9.11 E-04$ & $5.48 E-03$ & $5.58 E-03$ & $2.99 E-05$ & $1.80 E-04$ & $1.82 E-04$ \\
\hline B1210 & $1.72 E-09$ & $1.46 E-03$ & $4.35 E-03$ & $5.64 E-11$ & $4.80 E-05$ & $1.42 E-04$ \\
\hline B1211 & $6.35 E-05$ & $6.63 E-02$ & $1.29 E-01$ & $1.87 E-06$ & $1.58 E-03$ & $2.70 E-03$ \\
\hline B1212 & $1.32 E-03$ & $3.75 E+01$ & $2.36 E+01$ & $1.51 E-08$ & $4.17 E-04$ & $2.92 E-04$ \\
\hline B1213 & $3.86 E-04$ & $3.75 E-01$ & $8.84 E-01$ & $1.88 E-09$ & $1.86 E-06$ & $1.27 E-05$ \\
\hline B1214 & $9.11 E-04$ & $5.48 E-03$ & $5.58 E-03$ & $2.99 E-05$ & $1.80 E-04$ & $1.82 E-04$ \\
\hline PO210 & $2.19 E-12$ & $1.46 E-03$ & $4.35 E-03$ & $7.17 E-14$ & $4.80 E-05$ & $1.42 E-04$ \\
\hline P0211 & $1.78 E-07$ & $1.86 E-04$ & $3.61 E-04$ & $5.23 E-09$ & $4.42 E-06$ & $7.56 E-06$ \\
\hline PO212 & $8.45 E-04$ & $2.40 E+01$ & $1.51 E+01$ & $9.68 E-09$ & $2.67 E-04$ & $1.87 E-04$ \\
\hline PO213 & $3.77 E-04$ & $3.67 E-01$ & $8.65 E-01$ & $1.83 E-09$ & $1.82 E-06$ & $1.24 E-05$ \\
\hline PO214 & $9.11 E-04$ & $5.48 E-03$ & $5.58 E-03$ & $2.99 E-05$ & $1.80 E-04$ & $1.82 E-04$ \\
\hline PO215 & $6.35 E-05$ & $6.63 E-02$ & $1.29 E-01$ & $1.87 E-06$ & $1.58 E-03$ & $2.70 E-03$ \\
\hline PO216 & $3.61 E-03$ & $3.75 E+01$ & $2.36 E+01$ & $4.06 E-08$ & $4.17 E-04$ & $2.92 E-04$ \\
\hline
\end{tabular}

9

B-11 
HNF-2110 Rev 0

\section{ENGINEERING ANALYSIS/DESIGN CALCULATION}

Doc, No. EBU-RCAL-001 ReV Subject: ILAW Shielding Evaluation Preparer: Anthony Savino Checker: John McCoy Section Chief: Janet McFadden Project No. $\quad 772028$ Page_10_of $5 \underline{55}$

\begin{tabular}{|c|c|c|c|c|c|c|}
\hline \multirow{2}{*}{ Isotope } & \multicolumn{3}{|c|}{ Total for All Phase 1 Tanks } & \multicolumn{3}{|c|}{ Tank AZ-101 } \\
\hline & Initial & 10 yrs & 50 yrs & Initial & 10 yrs & 50 yrs \\
\hline PO218 & $9.12 \mathrm{E}-04$ & $5.48 E-03$ & $5.58 \varepsilon-03$ & $2.99 E-05$ & $1.80 \mathrm{E}-04$ & $1.82 \mathrm{E}-04$ \\
\hline AT217 & $3.86 \mathrm{E}-04$ & $3.75 \mathrm{E}-01$ & $8.84 E-01$ & $1.88 E-09^{\circ}$ & $1.86 E-06$ & 1.27E-05 \\
\hline RN219 & $6.35 \mathrm{E}-05$ & $6.63 \mathrm{E}-02$ & 1.29E-01 & $1.87 \mathrm{E}-06$ & $1.58 \mathrm{E}-03$ & $2.70 E-03$ \\
\hline RN 220 & $3.61 E-03$ & $3.75 E+01$ & $2.36 E+01$ & $4.06 E-08$ & 4.17E-04 & $2.92 \mathrm{E}-04$ \\
\hline $\mathrm{RN} 222$ & $9.12 E-04$ & $5.48 \mathrm{E}-03$ & $5.58 \mathrm{E}-03$ & $2.99 E-05$ & $1.80 E-04$ & $1.82 \mathrm{E}-04$ \\
\hline FR221 & $3.86 \mathrm{E}-04$ & $3.75 E-01$ & $8.84 E-01$ & $1.88 \mathrm{E}-09$ & $1.86 \mathrm{E}-06$ & $1.27 \mathrm{E}-05$ \\
\hline FR223 & $4.70 E-04$ & $9.14 \mathrm{E}-04$ & $1.78 \mathrm{E}-03$ & $1.38 E-05$ & $2.17 \mathrm{E}-05$ & $3.72 \mathrm{E}-05$ \\
\hline RA223 & $6.35 E-05$ & $6.63 \mathrm{E}-02$ & $1.29 \varepsilon-01$ & 1.87E-06 & $1.58 \mathrm{E}-03$ & $2.70 \varepsilon-03$ \\
\hline RA224 & $3.61 \mathrm{E}-03$ & $3.75 E+01$ & $2.36 E+01$ & 4.06E-08 & 4.17E-04 & $2.92 E-04$ \\
\hline RA225 & $1.13 \mathrm{E}-02$ & $3.75 \mathrm{E}-01$ & 8.84E-01 & 5.49E-08 & $1.86 \mathrm{E}-06$ & $1.27 \mathrm{E}-05$ \\
\hline RA226 & $5.50 E-03$ & $5.48 E-03$ & $5.58 \mathrm{E}-03$ & $1.80 \mathrm{E}-04$ & 1.80E-04 & $1.82 E-04$ \\
\hline RA228 & $1.06 E+01$ & $4.48 E+00$ & $1.13 E+00$ & & & \\
\hline AC225 & $3.86 \mathrm{E}-04$ & $3.75 \mathrm{E}-01$ & $8.84 \mathrm{E}-01$ & $1.88 E-09$ & 1.86E-06 & $1.27 E-05$ \\
\hline $\mathrm{AC2} 27$ & $3.40 \mathrm{E}-02$ & $6.62 \mathrm{E}-02$ & 1.29E-01 & $1.00 \mathrm{E}-03$ & $1.58 \mathrm{E}-03$ & $2.708-03$ \\
\hline$A C 228$ & $9.94 E+\infty 0$ & $4.48 E+00$ & $1.13 E+00$ & . & & \\
\hline TH227 & $1.22 \mathrm{E}-03$ & $6.54 \mathrm{E}-02$ & $1.27 \mathrm{E}-01$ & $3.59 \mathrm{E}-05$ & $1.56 \varepsilon-03$ & $2.66 E-03$ \\
\hline TH228 & $4.20 \mathrm{E}-02$ & $3.75 E+01$ & $2.36 \varepsilon+01$ & 4.57E-07 & $4.17 E-04$ & $2.92 E-04$ \\
\hline TH229 & 2.47E-01 & $3.75 E-01$ & 8.84E-01 & $1.20 \mathrm{E}-06$ & 1.86E-06 & 1.27E-05 \\
\hline TH230 & $1.03 \mathrm{E}-06$ & $3.76 \mathrm{E}-03$ & $1.88 \mathrm{E}-02$ & $2.96 \mathrm{E}-08$ & $1.08 \mathrm{E}-04$ & 5.45E-04 \\
\hline TH231 & $7.84 \mathrm{E}-01$ & $1.64 E+00$ & $1.64 \mathrm{E}+00$ & $2.11 E-02$ & $4.40 \mathrm{E}-02$ & $4.41 E-02$ \\
\hline $\mathrm{TH} 232$ & $1.07 E+00$ & $1.07 E+00$ & $1.07 E+00$ & & & \\
\hline TH234 & $1.26 E+00$ & $4.45 E+01$ & $4.45 E+01$ & $2.33 \mathrm{E}-\mathrm{O} 2$ & 8.20E-01 & 8.20E-01 \\
\hline PA231 & $1.52 \mathrm{E} \cdot 01$ & $1.52 \mathrm{E}-01$ & $1.54 \mathrm{E}-01$ & $3.10 E-03$ & $3.11 \mathrm{E}-03$ & $3.15 E-03$ \\
\hline PA 233 & $1.84 E+00$ & $7.27 E+01$ & $7.36 E+01$ & 4.97E-O1 & $1.97 E+01$ & $2.00 E+01$ \\
\hline
\end{tabular}

10 
HNF-2110 Rev 0

\section{ENGINEERING ANALYSIS/DESIGN CALCULATION}

Doc. No. EBU-RCAL-001 Rev Subject: ILAW Shielding Evaluation Preparer: Anthony Savino Checker: John McCoy Section Chief: Janet McFadden

Project No. 772028

Page_11_ of $\underline{55}$

Date_2/5/98

Date $215 / 98$

Date $2 / 6 / 98$

\begin{tabular}{|c|c|c|c|c|c|c|}
\hline \multirow{2}{*}{ Isotope } & \multicolumn{3}{|c|}{ Total for All Phase 1 Tanks } & \multicolumn{3}{|c|}{ Tank AZ-101 } \\
\hline & Initial & $10 \mathrm{yrs}$ & 50 yrs & Initial & 10 yrs & 50 yrs \\
\hline PA234M & $1.26 E+00$ & $4.45 \mathrm{E}+01$ & $4.45 E+01$ & $2.33 E-02$ & 8.20E-01 & 8.20E-01 \\
\hline $\mathrm{PA} 234^{\circ}$ & $1.04 \mathrm{E}-03$ & $5.78 \mathrm{E}-02$ & $5.78 E-02$ & $1.91 \mathrm{E}-05$ & $1.07 E-03$ & $1.07 \mathrm{E}-03$ \\
\hline U 232 & $3.54 E+01$ & $3.21 E+01$ & $2.18 E+01$ & $4.60 E-04$ & $4.18 \mathrm{E}-04$ & 2.85E-04 \\
\hline บ 233 & $1.36 \mathrm{E} \div 02$ & $1.36 \mathrm{E}+02$ & $1.36 E+02$ & $2.70 \mathrm{E}-04$ & $1.13 \mathrm{E}-03$ & 4.60E-03 \\
\hline U 234 & $4.18 E+01$ & $4.18 E+01$ & $4.19 E+01$ & $1.20 E+00$ & $1.21 E+00$ & $1.22 E+00$ \\
\hline U 235 & $1.64 E+00$ & $1.64 E+00$ & $1.64 E+00$ & $4.40 E-02$ & $4.40 E-02$ & $4.41 E-02$ \\
\hline$\cup 236$ & $2.20 \mathrm{E}+00$ & $2.20 E+00$ & $2.20 E+00$ & 9.90E-02 & 9.91E-02 & $9.94 \mathrm{E}-02$ \\
\hline$\cup 237$ & $9.59 \mathrm{E}-02$ & $6.08 \mathrm{E}-01$ & 8.87E-02 & 2.39E-02 & $1.52 E-01$ & $2.21 \varepsilon-02$ \\
\hline บ 238 & $4.45 E+01$ & $4.45 E+01$ & $4.45 E+01$ & $8.20 E-01$ & $8.20 E-01$ & $8.20 \mathrm{OE}-01$ \\
\hline NP237 & $7.25 E+01$ & $7.27 E+01$ & $7.36 E+01$ & $1.96 E+01$ & $1.97 E+01$ & $2.00 E+01$ \\
\hline NP239 & $3.70 E \div 00$ & $1.45 E+01$ & $1.44 E+01$ & $2.55 \varepsilon+00$ & $9.98 E+00$ & $9.94 E+00$ \\
\hline PU238 & $5.24 E+02$ & $4.85 E+02$ & $3.53 E+02$ & $1.65 E+02$ & $1.53 E+02$ & $1.11 \mathrm{E}+02$ \\
\hline PU239 & $3.04 E+03$ & $3.04 E+03$ & $3.03 E+03$ & $9.58 E+02$ & $9.58 E+02$ & $9.57 E+02$ \\
\hline PU240 & $8.71 E+02$ & $8.71 E+02$ & $8.67 E+02$ & $2.72 E+02$ & $2.72 E+02$ & $2.71 E+02$ \\
\hline PU241 & $4.01 E \div 04$ & $2.48 E+04$ & $3.61 E+03$ & $1.00 E+04$ & $6.18 E+03$ & $9.01 E+02$ \\
\hline PU242 & $1.64 \mathrm{E}-01$ & $1.64 \mathrm{E}-01$ & $1.64 \mathrm{E}-01$ & $7.40 E-02$ & $7.40 \mathrm{E}-02$ & $7.40 \mathrm{E}-02$ \\
\hline AM241 & $6.73 E \div 04$ & $6.67 E+04$ & $6.33 E+04$ & $2.26 E+04$ & $2.24 E+04$ & $2.12 E+04$ \\
\hline AM243 & $1.45 \mathrm{E}+01$ & $1.45 \mathrm{E}+01$ & $1.44 E+01$ & $9.99 E+00$ & $9.98 E+00$ & $9.94 E+00$ \\
\hline $\mathrm{CM} 242$ & $4.13 E \div 01$ & 7.60E-06 & 0.00 & $2.53 E+01$ & $4.65 \mathrm{E}-06$ & 0.00 \\
\hline $\mathrm{CM} 243$ & $6.91 E+00$ & $5.42 E+00$ & $2.05 E+00$ & $4.36 \mathrm{E}+00$ & $3.42 \mathrm{E}+00$ & $1.29 E+00$ \\
\hline $\mathrm{CM} 244$ & $1.60 E+02$ & $1.09 E+02$ & $2.35 E+01$ & $1.02 E+02$ & $6.96 E+01$ & $1.51 E+01$ \\
\hline
\end{tabular}


HNF-2110 Rev 0

\section{ENGINEERING ANALYSIS/DESIGN CALCULATION}

Doc. No. EBU-RCAL-001 Rev.

Subject: ILAW Shielding Evaluation

Preparer: Anthony Savino

Checker: John McCoy

Section Chief: Janet McFadden

Project No. 772028

Page_12_ of $\underline{55}$

\begin{tabular}{|c|c|c|c|}
\hline \multicolumn{2}{|c|}{ Table 2: Elemental Composition of Glass Waste Material* } \\
\hline Element & $\begin{array}{c}\text { Weight } \\
\text { Fraction }\end{array}$ & $\begin{array}{c}\text { Elemental } \\
\text { Density in Glass } \\
\text { Marbles } \\
\text { g/cc }\end{array}$ & $\begin{array}{c}\text { Elemental } \\
\text { Density inside } \\
\text { Waste Package } \\
\text { g/cc }\end{array}$ \\
\hline $\mathrm{Na}$ & 0.141 & 0.371 & 0.247 \\
\hline $\mathrm{Al}$ & 0.082 & 0.132 & 0.088 \\
\hline $\mathrm{Si}$ & 0.251 & 0.683 & 0.456 \\
\hline $\mathrm{K}$ & 0.018 & 0.032 & 0.021 \\
\hline $\mathrm{B}$ & 0.017 & 0.039 & 0.026 \\
\hline $\mathrm{Ca}$ & 0.031 & 0.089 & 0.060 \\
\hline $\mathrm{O}$ & 0.461 & 1.154 & 0.769 \\
\hline Total & 1.000 & 2.500 & 1.667 \\
\hline
\end{tabular}

* From Savino 1997.

${ }^{b}$ Density in waste package $=2 / 3$ density in glass marbles 
HNF-2110 Rev 0

\section{ENGINEERING ANALYSIS/DESIGN CALCULATION}

Doc. No. EBU-RCAL-001 Rev

Rev. 0 Project No. 772028

Page_13_ of 55

Subject: ILAW Shielding Evaluation

Preparer: Anthony Savino

tid

Checker: John McCoy

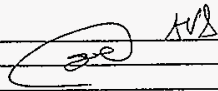

Table 3 Approximate \% Dose Contribution for Each Isotope

\begin{tabular}{|c|c|c|c|c|c|c|}
\hline \multirow[b]{2}{*}{ Isotope } & \multicolumn{3}{|c|}{ Total for All Phase 1 Tanks } & \multicolumn{3}{|c|}{ Tank AZ-101 } \\
\hline & Initial & 10 yrs & 50 yrs & Initial & $10 \mathrm{yrs}$ & 50 yrs \\
\hline C 14 & 0.00 & 0.00 & 0.00 & 0.00 & 0.00 & 0.00 \\
\hline $\mathrm{CO} 60^{*}$ & 3.25 & 0.95 & 0.02 & 12.64 & 8.47 & 0.32 \\
\hline SE 79 & 0.00 & 0.00 & 0.00 & 0.00 & 0.00 & 0.00 \\
\hline SR 90 & 0.04 & 0.03 & 0.05 & 0.00 & 0.01 & 0.02 \\
\hline Y $90^{*}$ & 79.11 & 69.25 & 95.71 & 7.87 & 15.55 & 44.04 \\
\hline ZR 93 & 0.00 & 0.00 & 0.00 & 0.00 & 0.00 & 0.00 \\
\hline NB $93 \mathrm{~m}$ & 0.00 & 0.00 & 0.00 & 0.00 & 0.00 & 0.00 \\
\hline TC 99 & 0.00 & 0.00 & 0.00 & 0.00 & 0.00 & 0.00 \\
\hline RU106 & 0.00 & 0.00 & 0.00 & 0.00 & 0.00 & 0.00 \\
\hline $\mathrm{RH} 106^{*}$ & 1.66 & 0.00 & 0.00 & 7.68 & 0.02 & 0.00 \\
\hline $\mathrm{CD} 713 \mathrm{~m}$ & 0.00 & 0.00 & 0.00 & 0.00 & 0.00 & 0.00 \\
\hline SN126 & 0.00 & 0.00 & .0 .00 & 0.00 & 0.00 & 0.00 \\
\hline SB125* & 2.51 & 0.24 & 0.00 & 11.18 & 2.37 & 0.00 \\
\hline $\mathrm{SB126*}$ & 0.00 & 0.01 & 0.02 & 0.00 & 0.02 & 0.15 \\
\hline $\mathrm{SB1} 26 \mathrm{~m}^{*}$ & 0.03 & 0.03 & 0.11 & 0.05 & 0.12 & 0.88 \\
\hline TE125m & 0.00 & 0.00 & 0.00 & 0.00 & 0.00 & 0.00 \\
\hline 1129 & 0.00 & 0.00 & 0.00 & 0.00 & 0.00 & 0.00 \\
\hline $\mathrm{CS} 134^{*}$ & 0.04 & 0.00 & 0.00 & 0.16 & 0.01 & 0.00 \\
\hline $\operatorname{CS} 137$ & 0.00 & 0.00 & 0.00 & 0.00 & 0.00 & 0.00 \\
\hline $\mathrm{BA} 137 \mathrm{~m}^{*}$ & 2.60 & 24.17 & 3.30 & 6.01 & 12.73 & 36.86 \\
\hline SM151 & 0.00 & 0.00 & 0.00 & 0.00 & 0.00 & 0.00 \\
\hline EU152* & 0.06 & 0.04 & 0.02 & 0.26 & 0.39 & 0.36 \\
\hline EU154* & 10.70 & 5.26 & 0.75 & 54.16 & 60.32 & 17.36 \\
\hline
\end{tabular}


HNF-2110 Rev 0

ENGINEERING ANALYSISIDESIGN CALCULATION

Doc. No. EBU-RCAL-001_Rev. 0 Project No. $\quad 772028$

Subject: ILAW Shielding Evaluation

Preparer: Anthony Savino

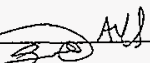

Checker: John McCoy

Section Chief:_Janet McFadden

Page_14_of 55

Date $2 / 5 / 98$

Date 2/5/98

Date 2/6/98

\begin{tabular}{|c|c|c|c|c|c|c|}
\hline \multirow[b]{2}{*}{ Isotope } & \multicolumn{3}{|c|}{ Total for All Phase 1 Tanks } & \multicolumn{3}{|c|}{ Tank AZ-101 } \\
\hline & Initial & 10 yrs & 50 yrs & Initial & 10 yrs & 50 yrs \\
\hline EU155 & 0.00 & 0.00 & 0.00 & 0.00 & 0.00 & 0.00 \\
\hline $\mathrm{TL} 207$ & 0.00 & 0.00 & 0.00 & 0.00 & 0.00 & 0.00 \\
\hline TL208 & 0.00 & $0: 01$ & 0.03 & 0.00 & 0.00 & 0.00 \\
\hline TL209 & 0.00 & 0.00 & 0.00 & 0.00 & 0.00 & 0.00 \\
\hline PB209 & 0.00 & 0.00 & 0.00 & 0.00 & 0.00 & 0.00 \\
\hline PB210 & 0.00 & 0.00 & 0.00 & 0.00 & 0.00 & 0.00 \\
\hline PB211 & 0.00 & 0.00 & 0.00 & 0.00 & 0.00 & 0.00 \\
\hline PB212 & 0.00 & 0.00 & 0.00 & 0.00 & 0.00 & 0.00 \\
\hline PB214 & 0.00 & 0.00 & 0.00 & 0.00 & 0.00 & 0.00 \\
\hline $\mathrm{B} 1210$ & 0.00 & 0.00 & 0.00 & 0.00 & 0.00 & 0.00 \\
\hline $\mathrm{B} 1211$ & 0.00 & 0.00 & 0.00 & 0.00 & 0.00 & 0.00 \\
\hline $\mathrm{B} \backslash 212$ & 0.00 & 0.00 & 0.00 & 0.00 & 0.00 & 0.00 \\
\hline B 1213 & 0.00 & 0.00 & 0.00 & 0.00 & 0.00 & 0.00 \\
\hline $\mathrm{B} 1214$ & 0.00 & 0.00 & 0.00 & 0.00 & 0.00 & 0.00 \\
\hline $\mathrm{PO} 214$ & 0.00 & 0.00 & 0.00 & 0.00 & 0.00 & 0.00 \\
\hline RN219 & 0.00 & 0.00 & 0.00 & 0.00 & 0.00 & 0.00 \\
\hline RN220 & 0.00 & 0.00 & 0.00 & 0.00 & 0.00 & 0.00 \\
\hline $\mathrm{RN} 222$ & 0.00 & 0.00 & 0.00 & 0.00 & 0.00 & 0.00 \\
\hline FR221 & 0.00 & 0.00 & 0.00 & 0.00 & 0.00 & 0.00 \\
\hline RA223 & 0.00 & 0.00 & 0.00 & 0.00 & 0.00 & 0.00 \\
\hline RA224 & 0.00 & 0.00 & 0.00 & 0.00 & 0.00 & 0.00 \\
\hline RA225 & 0.00 & 0.00 & 0.00 & 0.00 & 0.00 & 0.00 \\
\hline RA226 & 0.00 & 0.00 & 0.00 & 0.00 & 0.00 & 0.00 \\
\hline RA228 & 0.00 & 0.00 & 0.00 & 0.00 & 0.00 & 0.00 \\
\hline$A C 225$ & 0.00 & 0.00 & 0.00 & 0.00 & 0.00 & 0.00 \\
\hline
\end{tabular}


HNF-2110 Rev 0

ENGINEERING ANALYSIS/DESIGN CALCULATION

Doc. No. EBU-RCAL-001 Rev. 0 Subject: ILAW Shielding Evaluation Preparer: Anthony Savino

Checker: John McCoy

Section Chief: Janet McFadden

Project No. 772028

Page_15_ of $\underline{55}$

Date 2/5/98

Date $2 / 5 / 98$

Date 2/6/98

\begin{tabular}{|c|c|c|c|c|c|c|}
\hline \multirow[b]{2}{*}{ Isotope } & \multicolumn{3}{|c|}{ Total for All Phase 1 Tanks } & \multicolumn{3}{|c|}{ Tank AZ-101 } \\
\hline & Initial & 10 yrs & 50 yrs & Initial & 10 yrs & 50 yrs \\
\hline $\mathrm{AC} 227$ & 0.00 & 0.00 & 0.00 & 0.00 & 0.00 & 0.00 \\
\hline $\mathrm{AC228}$ & 0.00 & 0.00 & 0.00 & 0.00 & 0.00 & 0.00 \\
\hline $\mathrm{TH} 227$ & 0.00 & 0.00 & 0.00 & 0.00 & 0.00 & 0.00 \\
\hline TH228 & 0.00 & 0.00 & 0.00 & 0.00 & 0.00 & 0.00 \\
\hline $\mathrm{TH} 229$ & 0.00 & 0.00 & 0.00 & 0.00 & 0.00 & 0.00 \\
\hline TH230 & 0.00 & 0.00 & 0.00 & 0.00 & 0.00 & 0.00 \\
\hline$T H 231$ & 0.00 & 0.00 & 0.00 & 0.00 & 0.00 & 0.00 \\
\hline TH232 & 0.00 & 0.00 & 0.00 & 0.00 & 0.00 & 0.00 \\
\hline TH234 & 0.00 & 0.00 & 0.00 & 0.00 & 0.00 & 0.00 \\
\hline PA231 & 0.00 & 0.00 & 0.00 & 0.00 & 0.00 & 0.00 \\
\hline PA233 & 0.00 & 0.00 & 0.00 & 0.00 & 0.00 & 0.00 \\
\hline PA234m & 0.00 & 0.00 & 0.00 & 0.00 & 0.00 & 0.00 \\
\hline PA234 & 0.00 & 0.00 & 0.00 & 0.00 & 0.00 & 0.00 \\
\hline$\cup 232$ & 0.00 & 0.00 & 0.00 & 0.00 & 0.00 & 0.00 \\
\hline U 233 & 0.00 & 0.00 & 0.00 & 0.00 & 0.00 & 0.00 \\
\hline U 234 & 0.00 & 0.00 & 0.00 & 0.00 & 0.00 & 0.00 \\
\hline$\cup 235$ & 0.00 & 0.00 & 0.00 & 0.00 & 0.00 & 0.00 \\
\hline U 236 & 0.00 & 0.00 & 0.00 & 0.00 & 0.00 & 0.00 \\
\hline U 237 & 0.00 & 0.00 & 0.00 & 0.00 & 0.00 & 0.00 \\
\hline U 238 & 0.00 & 0.00 & 0.00 & 0.00 & 0.00 & 0.00 \\
\hline NP237 & 0.00 & 0.00 & 0.00 & 0.00 & 0.00 & 0.00 \\
\hline NP239 & 0.00 & 0.00 & 0.00 & 0.00 & 0.00 & 0.00 \\
\hline PU238 & 0.00 & 0.00 & 0.00 & 0.00 & 0.00 & 0.00 \\
\hline PU239 & 0.00 & 0.00 & 0.00 & 0.00 & 0.00 & 0.00 \\
\hline PU240 & 0.00 & 0.00 & 0.00 & 0.00 & 0.00 & 0.00 \\
\hline
\end{tabular}


HNF-2110 Rev 0

\section{ENGINEERING ANALYSIS/DESIGN CALCULATION}

Doc. No. EBU-RCAL-001 Rev Subject: ILAW Shielding Evaluation Preparer: Anthony Savino Checker: John McCov

Section Chief: Janet McFadden

Project No. 772028

as

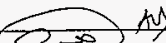

62
Page_16_ of 55

Date 2/5/98

Date 2/5/98

Date 2/6/98

\begin{tabular}{|c|c|c|c|c|c|c|}
\hline \multirow{2}{*}{ Isotope } & \multicolumn{2}{|c|}{ Total for All Phase 1 Tanks } & \multicolumn{3}{c|}{ Tank AZ-101 } \\
\cline { 2 - 7 } & Initial & $10 \mathrm{yrs}$ & $50 \mathrm{yrs}$ & Initial & $10 \mathrm{yrs}$ & $50 \mathrm{yrs}$ \\
\hline PU241 & 0.00 & 0.00 & 0.00 & 0.00 & 0.00 & 0.00 \\
\hline PU242 & 0.00 & 0.00 & 0.00 & 0.00 & 0.00 & 0.00 \\
\hline AM241 & 0.00 & 0.00 & 0.00 & 0.00 & 0.00 & 0.00 \\
\hline AM243 & 0.00 & 0.00 & 0.00 & 0.00 & 0.00 & 0.00 \\
\hline CM242 & 0.00 & 0.00 & 0.00 & 0.00 & 0.00 & 0.00 \\
\hline CM243 & 0.00 & 0.00 & 0.00 & 0.00 & 0.00 & 0.00 \\
\hline CM244 & 0.00 & 0.00 & 0.00 & 0.00 & 0.00 & 0.00 \\
\hline
\end{tabular}

* Isotope contributing $>0.1 \%$ to the total direct dose. 
HNF-2110 Rev 0

ENGINEERING ANALYSIS/DESIGN CALCULATION

Doc. No. EBU-RCAL-001 Rev.

Rev. 0

Project No. 772028

Page_17_of $\underline{55}$

Subject: ILAW Shielding Evaluation

Preparer: Anthonv Savino

Checker: John McCoy

Date 2/5/98

Date $\underline{2 / 5 / 98}$

Section Chief: Janet McFadden

Date 2/6/98

\begin{tabular}{|c|c|c|c|c|c|c|c|c|c|}
\hline $\mathrm{cm}$ & $\mathrm{Co60}$ & Sr90* & Ru106 & Sb125 & $\operatorname{sn} 126^{\circ}$ & Cs134 & $\operatorname{Cs} 137^{\circ}$ & Eu152 & EuT54 \\
\hline 1 & $7.88 E-01$ & $1.01 \mathrm{E}-03$ & $5.10 E-02$ & $8.58 \mathrm{E}-02$ & $3.64 \mathrm{E}-01$ & $3.86 \mathrm{E}-01$ & $1.35 \varepsilon .01$ & $3.06 \mathrm{E}-01$ & $3.46 \varepsilon-01$ \\
\hline 2 & $4.78 \mathrm{E}-01$ & $4.708-04$ & $2.66 \mathrm{E}-02$ & $4.22 \varepsilon-02$ & $2.05 E-01$ & $2.07 \mathrm{E}-01$ & $7.10 \mathrm{E}-02$ & 1.77E-01 & $2.02 \mathrm{E}-01$ \\
\hline 4 & $1.92 \mathrm{E}-01$ & $1.31 \mathrm{E}-04$ & $8.14 E-03$ & $1.14 \mathrm{E}-02$ & $7.15 \mathrm{E}-02$ & $6.59 \mathrm{E}-02$ & $2.15 \varepsilon-02$ & $6.65 \mathrm{E}-02$ & 7.57E-02 \\
\hline 6 & $8.04 \mathrm{E} \cdot 02$ & 4.26E-05 & 2.69E-03 & $3.27 \varepsilon-03$ & $2.64 \mathrm{E}-02$ & $2.21 \mathrm{E}-02$ & $6.80 E-03$ & $2.66 \mathrm{E}-02$ & $3.00 E-02$ \\
\hline 8 & $3.44 \mathrm{E} \cdot 02$ & $1.51 \mathrm{E} .05$ & $9.37 E \cdot 04$ & $9.63 \mathrm{E} \cdot 04$ & $1.00 \mathrm{E}-\mathrm{O} 2$ & $7.64 \mathrm{E}-03$ & $2.19 \mathrm{E}-\mathrm{O} 3$ & 1.10E-02 & $1.23 \mathrm{E}-\mathrm{O} 2$ \\
\hline 10 & $1.49 \mathrm{E} \cdot 02$ & 5.67E.06 & $3.41 E-04$ & $2.89 \mathrm{E} \cdot 04$ & $3.90 \mathrm{E}-03$ & $2.70 \mathrm{E}-03$ & $7.15 \varepsilon-04$ & $4.61 \mathrm{E} \cdot 03$ & $5.11 \varepsilon .03$ \\
\hline 12 & $6.48 \varepsilon \cdot 03$ & 2.24E-06 & $1.30 \mathrm{E}-04$ & $8.79 \varepsilon .05$ & $1.54 \mathrm{E}-03$ & $9.72 \mathrm{E}-04$ & $2.35 \mathrm{E}-04$ & $1.97 \varepsilon .03$ & $2.16 \mathrm{E}-03$ \\
\hline 14 & $2.84 \varepsilon .03$ & 9.148 .07 & $5.09 \mathrm{E}-05$ & $2.70 E-05$ & $6.17 \mathrm{E}-04$ & $3.56 \mathrm{E}-04$ & 7.75E-05 & 8.51E.04 & $9.22 \mathrm{E} \cdot 04$ \\
\hline 16 & $1.25 \mathrm{E} \cdot 03$ & 3.858 .07 & $2.07 \mathrm{E}-05$ & $8.39 \varepsilon-06$ & $2.51 \mathrm{E}-04$ & $1.33 E-04$ & $2.56 \mathrm{E} \cdot 05$ & $3.71 \mathrm{E}-04$ & $3.98 \mathrm{E}-04$ \\
\hline 18 & 5.51E.04 & $1.66 \mathrm{E}-07$ & $8.61 \mathrm{E}-06$ & $2.63 \mathrm{E}-06$ & $1.03 \mathrm{E}-04$ & $5.04 \mathrm{E}-05$ & $8.52 E-06$ & $1.63 \dot{\mathrm{E}} \cdot 04$ & $1.73 \mathrm{E} \cdot 04$ \\
\hline 20 & $2.44 E \cdot 04$ & $7.34 \mathrm{E} .08$ & $3.67 \varepsilon-06$ & 8.268 .07 & $4.30 \mathrm{E}-05$ & $1.94 \mathrm{E}-05$ & $2.84 \mathrm{E}-06$ & 7.21E.05 & $7.59 \mathrm{E}-05$ \\
\hline
\end{tabular}

- Includes $5 r 90$ and Y90

- Includes Ru106 and Rh106

- Includes Sn126, Sb126m, and Sb126

- Includes Cs137 and Ba137m 
HNF-2110 Rev 0

ENGINEERING ANALYSIS/DESIGN CALCULATION

Doc. No. EBU-RCAL-001 Rev.

Subject: ILAW Shielding Evaluation

Preparer: Anthony Savino

Checker: John McCov

Section Chief:_Janet McFadden

Project No. 772028

Page_18_ of 55

Date 2/5/98

Date 2/5/98

Date 2/6/98

\begin{tabular}{|c|c|c|c|}
\hline \multicolumn{2}{|c|}{ Table 5 } & \multicolumn{2}{c|}{ Polynomial Regression Fitting Coefficients } \\
\hline Isotope & $\mathrm{a}$ & $\mathrm{b}$ & $\mathrm{c}$ \\
\hline Co60 & 0.000654 & -0.197 & 0.075 \\
\hline Sr90 & 0.00313 & -0.279 & -2.774 \\
\hline Ru106 & 0.002311 & -0.265 & -1.052 \\
\hline Sb125 & 0.001031 & -0.284 & -0.807 \\
\hline Sn126 & 0.001191 & -0.23 & -0.229 \\
\hline Cs134 & 0.001292 & -0.252 & -0.18 \\
\hline Cs137 & 0.000641 & -0.258 & -0.631 \\
\hline Eu152 & 0.001104 & -0.212 & -0.327 \\
\hline Eu154 & 0.001048 & -0.213 & -0.27 \\
\hline
\end{tabular}


HNF-2110 Rev 0

\section{ENGINEERING ANALYSIS/DESIGN CALCULATION}

Doc. No. EBU-RCAL-001
Subject: ILAW Shielding Evaluation

Figure 1

\section{Dose Rate vs Package Wall Thickness for $1 \mathrm{Ci} / \mathrm{m} 3$ Activity Concentration}

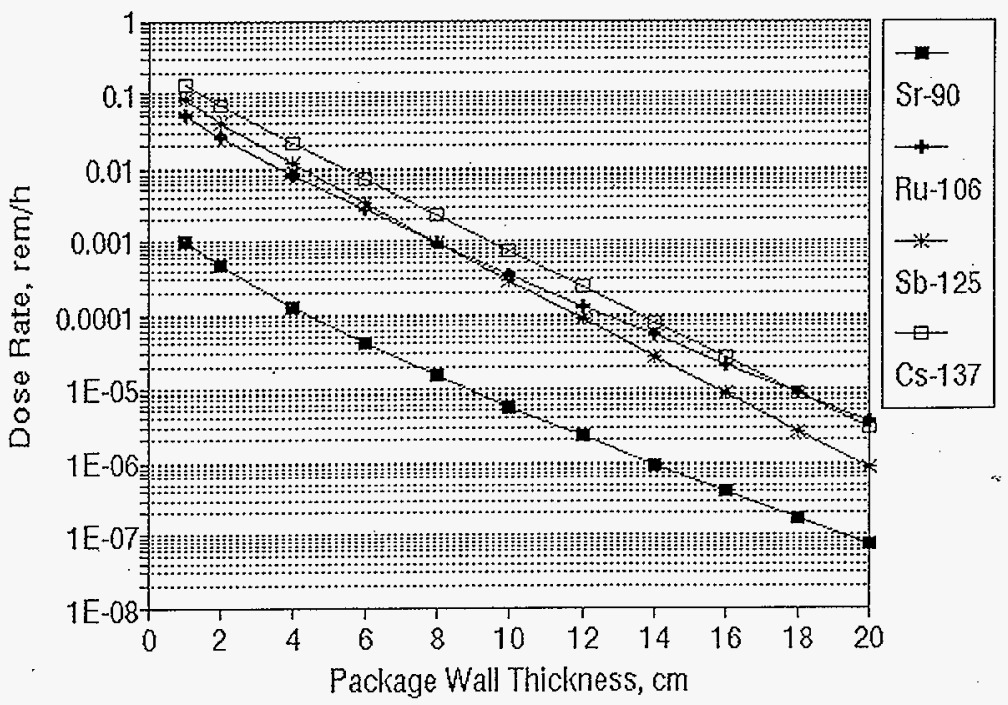


HNF-2110 Rev 0

\section{ENGINEERING ANALYSIS/DESIGN CALCULATION}

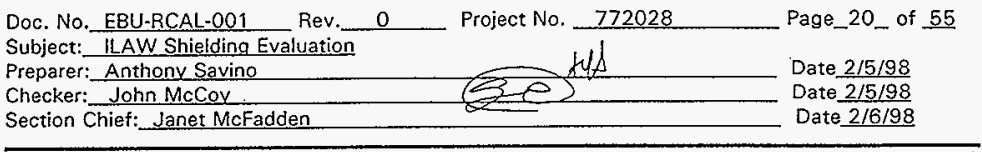

Figure 2

\section{Dose Rate vs Package Wall Thickness for $1 \mathrm{Ci} / \mathrm{m} 3$ Activity Concentration}

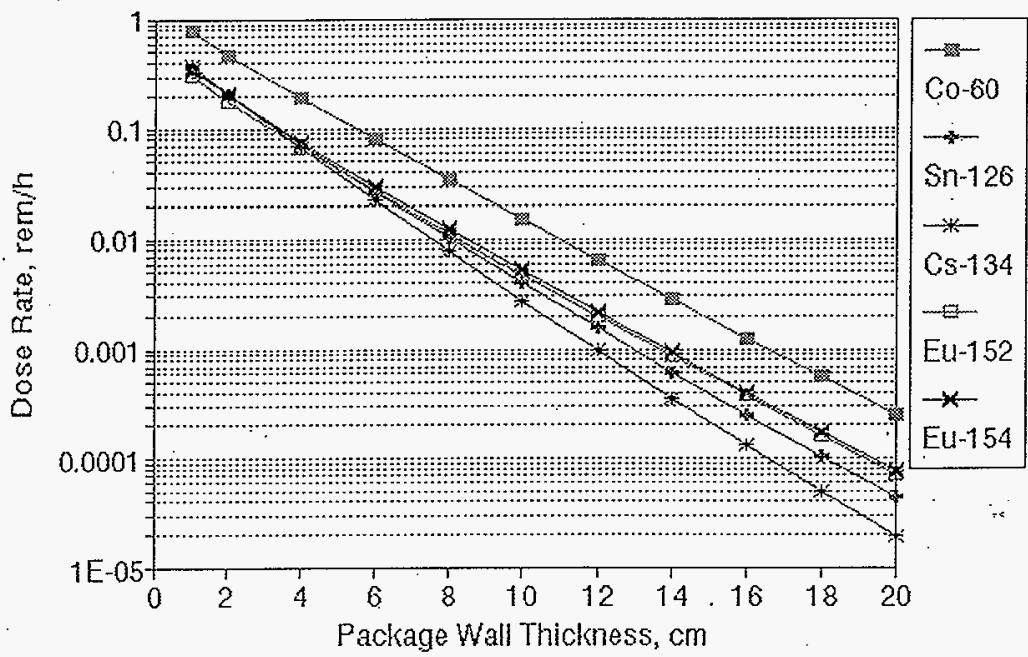


HNF-2110 Rev 0

(20)

ENGINEERING ANALYSIS/DESIGN CALCULATION

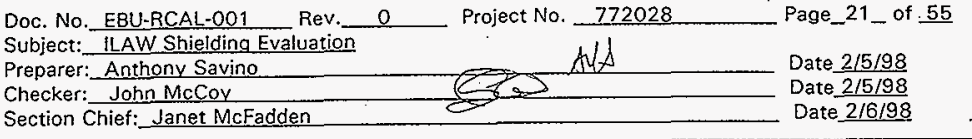

APPENDIXA

Spreadsheet of Radioactive Inveritory for Phase 1 Tanks

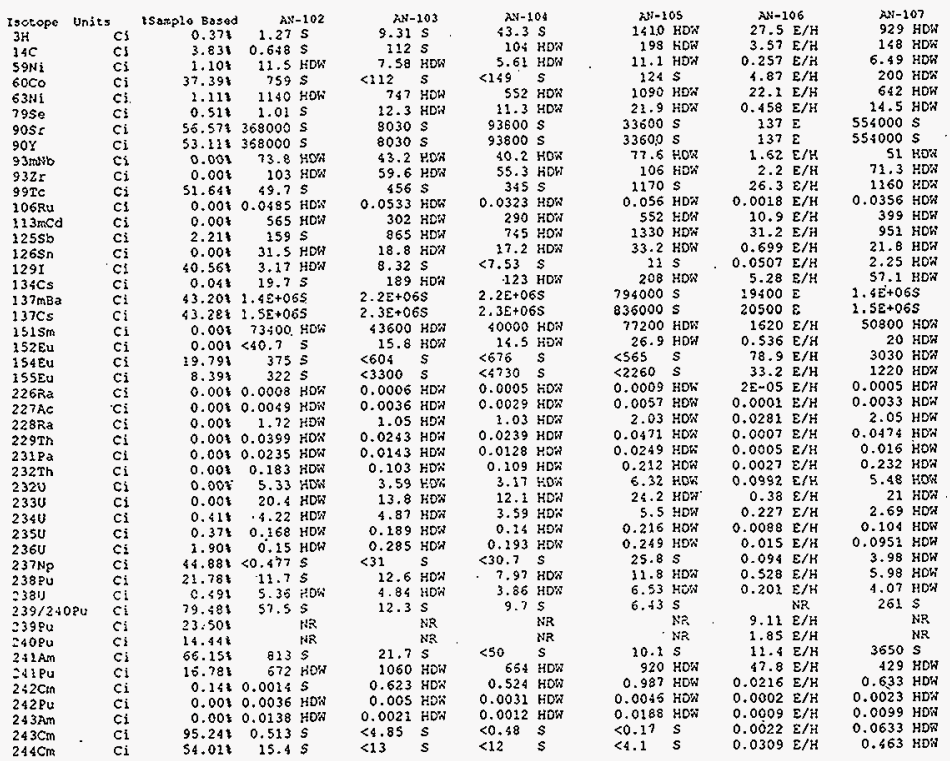


HNF-2110 Rev 0

\section{ENGINEERING ANALYSISIDESIGN CALCULATION}

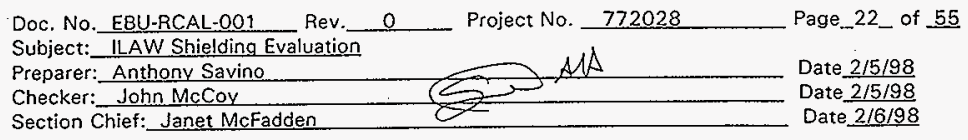

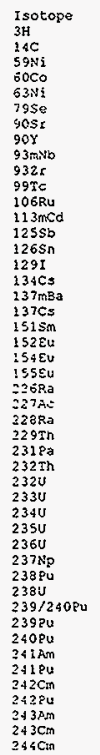

\begin{tabular}{|c|c|c|c|}
\hline $\begin{array}{l}\text { Units } \\
\text { Ci }\end{array}$ & $\begin{array}{r}\text { tSanple } 8 \\
0.374\end{array}$ & $\begin{array}{r}A N-1 \\
958\end{array}$ & HOH \\
\hline Ci & 3.831 & 124 & HDN \\
\hline Ci & 1.101 & 7.18 & HOW \\
\hline cí & 37.391 & 173 & HiDH \\
\hline $\mathrm{Cj}$ & 1.111 & 707 & HOW \\
\hline $\mathrm{CI}$ & 0.511 & 14.8 & HOH \\
\hline$-i$ & 56.57 & 31300 & $E$ \\
\hline $\mathrm{Ci}$ & 53.111 & 31300 & $E$ \\
\hline $\mathrm{Ci}$ & 0.001 & 52.4 & HDW \\
\hline $\mathrm{Ci}$ & $0.00 \mathrm{t}$ & 71.5 & $\mathrm{HDH}$ \\
\hline $\mathrm{Ci}$ & 51.648 & 922 & $\mathrm{HOH}$ \\
\hline $\mathrm{Ci}$ & 0.001 & 0.0607 & HDW \\
\hline $\mathrm{Ci}$ & 0.008 & 362 & HOW \\
\hline $\mathrm{Ci}$ & 2.211 & 1180 & HoW \\
\hline $\mathrm{Ci}$ & 0.001 & 22.6 & HDW \\
\hline Cí & 40.567 & 1.78 & HOW \\
\hline $\mathrm{Ci}$ & 0.041 & 265 & HOW \\
\hline $\mathrm{Ci}$ & 43.208 & $1.7 \mathrm{E}+0$ & \\
\hline $\mathrm{Ci}$ & $\{3.285$ & $1.85+0$ & $6 \varepsilon$ \\
\hline $\mathrm{Ci}$ & 0.008 & 52400 & $\mathrm{HD}$ ' \\
\hline $\mathrm{Ci}$ & 0.008 & 17.9 & HDW \\
\hline $\mathrm{Ci}$ & 19.753 & 2690 & HON \\
\hline $\mathrm{Ci}$ & 8.399 & 1140 & HD' \\
\hline $\mathrm{Ci}$ & $0.00 t$ & 0.0005 & HEK \\
\hline $6:$ & $\dot{0}-\dot{0} 0 \mathrm{t}$ & 0.004 & sor \\
\hline $\mathrm{Cl}$ & 0.001 & 1.31 & Hes' \\
\hline$C i$ & $0.00 t$ & 0.0304 & MDW \\
\hline $\mathrm{Ci}$ & 0.004 & 0.0271 & HOW \\
\hline Ci & 0.001 & 0.127 & Hish \\
\hline $\mathrm{Ci}_{\mathbf{2}}$ & 0.008 & 5.53 & HON \\
\hline $\mathrm{Ci}$ & 0.001 & 27.4 & $\mathrm{HDN}$ \\
\hline $\mathrm{Ci}$ & 0.418 & 10.1 & $\mathrm{HD}$ \\
\hline $\mathrm{Ci}$ & $0.37 t$ & 0.39 & FDW \\
\hline $\mathrm{Cl}$ & 2.907 & 0.7 & HDW \\
\hline$C \mathbf{i}$ & 44.869 & 3.31 & How \\
\hline $\mathrm{Cl}$ & 21.761 & 83.4 & HOW \\
\hline $\mathrm{Ci}$ & 0.454 & 8.79 & HDW \\
\hline $\mathrm{Ci}$ & 79.483 & & $N R$ \\
\hline $\mathrm{Ci}$ & $23.5 C 3$ & 817 & HDN \\
\hline $\mathrm{Ci}$ & 14.448 & 225 & How \\
\hline Ci & 60.155 & 388 & HOW \\
\hline$c i$ & 16.781 & 8330 & How \\
\hline $\mathrm{ci}$ & 0.14 & 0.698 & HO \\
\hline $\mathrm{Ci}$ & $0.00 \mathrm{t}$ & 0.0319 & $40 \%$ \\
\hline $\mathbf{C i}$ & 0.001 & 0.0311 & HDK \\
\hline $\mathbf{C i}$ & 95.241 & 0.0712 & HOW \\
\hline$C i$ & $54.01\}$ & 1 & How \\
\hline
\end{tabular}

$A 2-101$
$4 \mathrm{~S}$
$0.43 \mathrm{~S}$
$19.9 \mathrm{E}$
$4610 \mathrm{E}$
$2300 \mathrm{E}$
$41.3 \mathrm{E}$
$6.4 \mathrm{E}+06 \mathrm{E}$
$6.4 \mathrm{E}+06 \mathrm{E}$
$87.4 \mathrm{E}$
$199 \mathrm{E}$
$1100 \mathrm{E}$
$106000 \mathrm{E}$
$2120 \mathrm{E}$
$131000 \mathrm{E}$
$65.7 \mathrm{E}$
$7.1 \mathrm{~S}$
$43400 \mathrm{E}$
$6.9 \mathrm{E}+06 \mathrm{E}$
$7.4 \mathrm{E}+06 \mathrm{E}$
$142000 \mathrm{E}$
$273 \mathrm{E}$
$57600 \mathrm{E}$
$71500 . \mathrm{E}$
$0.0002 \mathrm{E}$
$0.001 \mathrm{E}$
$1.3 \mathrm{E}-08 \mathrm{E}$
$1.2 \mathrm{E}-06 \mathrm{E}$
$0.0031 \mathrm{E}$
$1.6 \mathrm{E}-08 \mathrm{E}$
$0.0005 \mathrm{~S} / \mathrm{E}$
$0.0003 \mathrm{~S} / \mathrm{E}$
$1.2 \mathrm{~S} / \mathrm{E}$
$0.044 \mathrm{~S} / \mathrm{E}$
$0.099 \mathrm{~S} / \mathrm{E}$
$19.6 \mathrm{E}$
$165 \mathrm{~S}$
$0.82 \mathrm{~S} / \mathrm{E}$
$958 \mathrm{HR}$
$272 \mathrm{~S}$
$22600 \mathrm{E}$
$9990 \mathrm{~S}$
$25.4 \mathrm{E}$
$0.074 \mathrm{E}$
$9.98 \mathrm{E}$
$4.36 \mathrm{E}$
$102 \mathrm{E}$

\begin{tabular}{|c|c|}
\hline $\begin{array}{l}\text { A2-1 } \\
14700\end{array}$ & 102 \\
\hline $0 . \varepsilon 3$ & \\
\hline 10.8 & \\
\hline 3420 & \\
\hline 1250 & \\
\hline $\begin{aligned} 22.8 \\
3.72+06\end{aligned}$ & \\
\hline $3.7 E+065$ & \\
\hline 43.3 & \\
\hline 111 & \\
\hline $\begin{array}{r}559 \\
26200\end{array}$ & $s$ \\
\hline $\begin{array}{r}26200 \\
1220\end{array}$ & \\
\hline $\begin{array}{r}1220 \\
92700\end{array}$ & \\
\hline 35.4 & \\
\hline 1.52 & \\
\hline 41200 & \\
\hline $45+C 6$ & \\
\hline $4.35+06$ & \\
\hline 80200 & \\
\hline 142 & \\
\hline 23100 & \\
\hline 66900 & \\
\hline 8. $5 E-05 E$ & \\
\hline 0.0005 & \\
\hline $72-69$ & \\
\hline $6.85-07$ & \\
\hline 0.0018 & \\
\hline $\begin{array}{l}9.4 E-09 \\
0.0007\end{array}$ & \\
\hline 0.0004 & $s /$ \\
\hline 2.24 & \\
\hline $0.08 \xi 3$ & $s /$ \\
\hline 0,184 & \\
\hline $11.7 \mathrm{E}$ & \\
\hline $1 \notin 1$ & \\
\hline $1.53 \mathrm{~s}$ & \\
\hline$\ldots 7505$ & \\
\hline 3725 & \\
\hline 37700 & \\
\hline 17160 & \\
\hline 11.2 & \\
\hline 0.054 & \\
\hline $4.52 \mathrm{E}$ & \\
\hline 2.77 & \\
\hline
\end{tabular}

1380 HOW

204 HOW

$13 \mathrm{HOW}$

$1280 \mathrm{HDH}$

20.3 HDN

$125000 \mathrm{~S}$

$125000 \mathrm{~s}$
$125000 \mathrm{~s}$

72.1 HOW

99.5 HDW

$14600 \mathrm{~S}$

$0.0416 \mathrm{HDN}$

526 HOH

$30.6 \mathrm{HOW}$

$2.79 \mathrm{HDN}$

How

$2.1 \mathrm{E}+05 \mathrm{~S}$

$2.2 E+065$
71400

$71400 \mathrm{HDW}$
$24.6 \mathrm{HOW}$

$3730 \mathrm{HOK}$

1460 HON

0.0009 HDW

0.0054 HOA

0.865 Há

$0.025 \mathrm{HDH}$

0.0584 HOW

4.4 H!D

16.9 HDW

4.75 HDN

$0.192 \mathrm{HOW}$

$0.149 \mathrm{HDN}$

8.6 HOW

$5.56 \mathrm{HDN}$

$46.6 \mathrm{~S}$ $6 \mathrm{~S}$

$633 \stackrel{\mathrm{NR}}{\mathrm{S}}$

$633 \mathrm{~S}$

$584 \mathrm{HON}$
$0.938 \mathrm{HDN}$

0.0032 HON

0.0223 HON

$0.842 \mathrm{HDN}$

\begin{tabular}{|c|c|c|}
\hline$S Y-10$ & & TOTAI \\
\hline 3.16 & $\$$ & 19465.5 \\
\hline 105 & $K D N$ & 1000.48 \\
\hline 6.51 & HOH & 99.927 \\
\hline 205 & $s$ & 9623.87 \\
\hline 639 & HOR & 10369.1 \\
\hline 10.5 & HDS & 171.168 \\
\hline 79000 & $s$ & $1.1 \varepsilon+07$ \\
\hline 79000 & $\mathrm{~s}$ & $1.1 \mathrm{E}+07$ \\
\hline 37.3 & $\mathrm{HOH}$ & 579.92 \\
\hline$\$ 1.5$ & HDin & 929.9 \\
\hline 759 & $s$ & 21287 \\
\hline .0216 & Hor & 182200 \\
\hline 273 & HOH & 6619.9 \\
\hline 523 & $\mathrm{HPH}$ & 230473 \\
\hline 25.8 & HDiT & 293.299 \\
\hline 0.253 & $s$ & 38.2387 \\
\hline 9 & $\mathrm{HOW}$ & 85492.9 \\
\hline $1.12+06$ & & $2.4 E+07$ \\
\hline $1.1 E+06$ & & $2.5 E+07$ \\
\hline 36900 & HOÁ & 669520 \\
\hline 22.7 & HOR & 547.936 \\
\hline 1620 & s & 23.9 \\
\hline 1410 & $s$ & 143985 \\
\hline 0.0004 & HOA & 0.0055 \\
\hline 0.0028 & $\mathrm{HOH}$ & 0.03401 \\
\hline 0.556 & HON & 10.6391 \\
\hline 0.013 & HDN & 0.24695 \\
\hline 0.0128 & $\mathrm{HCH}$ & 0.15181 \\
\hline 0.0458 & $\mathrm{HOH}$ & 1.07291 \\
\hline 2.41 & HDX & 35.3304 \\
\hline 9.22 & Hot & 135.401 \\
\hline 2.39 & $H D X$ & 41.777 \\
\hline 0.0965 & $\mathrm{HOK}$ & 1.63656 \\
\hline 0.0752 & $\mathrm{HOH}$ & 2.1943 \\
\hline 2.74 & HOH & 72.464 \\
\hline 35.4 & $s$ & $\$ 23.978$ \\
\hline 2.86 & $\mathrm{HDH}$ & 44.421 \\
\hline 134 & s & 527.53 \\
\hline & $\mathrm{NR}$ & 3034.11 \\
\hline & NR & 870.85 \\
\hline 1440 & $s$ & 67267.2 \\
\hline 295 & HON & 40091.8 \\
\hline 0.47 & $\mathrm{HOH}$ & 41.496 \\
\hline .0016 & $H O H$ & 0.16342 \\
\hline & HOA & 14.4964 \\
\hline .0436 & HDA & 6.9102 \\
\hline & & 159.45 \\
\hline
\end{tabular}


HNF-2110 Rev 0

(i)

\section{ENGINEERING ANALYSIS/DESIGN CALCULATION}

Doc. No. EBU-RCAL-001 Rev. .0 Project No. 1772028
Subject: ILAW Shielding Evaluation
Preparer: Anthony Savino
Checker: John McCox
Section Chief: Janet McFadden

RRPENDIX B

ORIGEN2 Input Eile for. All Phase 1 Tanks

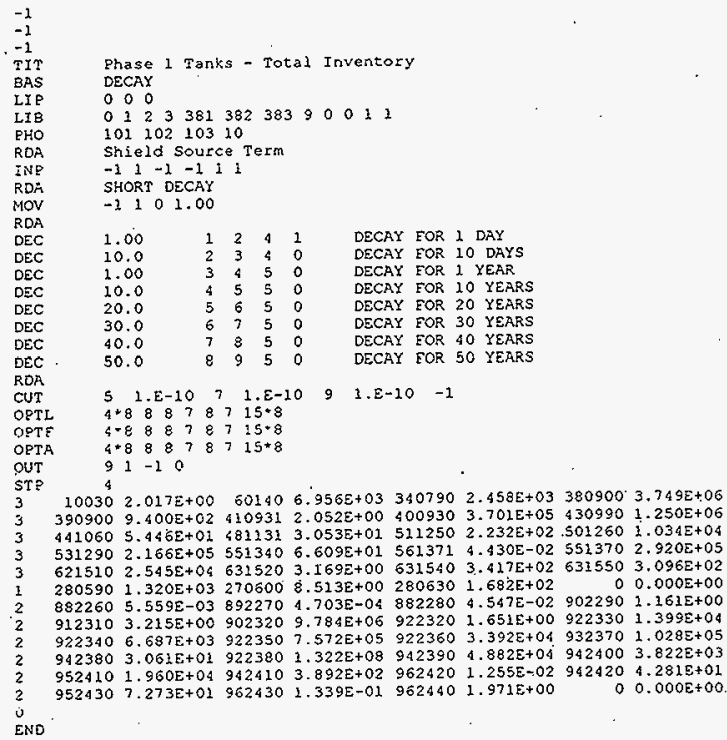


HNF-2110 Rev 0

\section{ENGINEERING ANALYSIS/DESIGN CALCULATION}

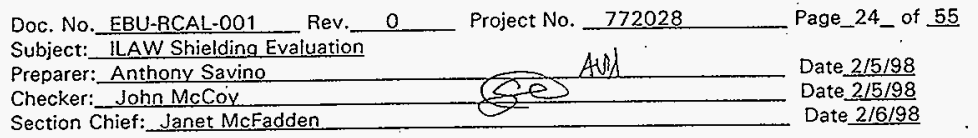

ORIGEN2 Inout Eile for Tank A2-101

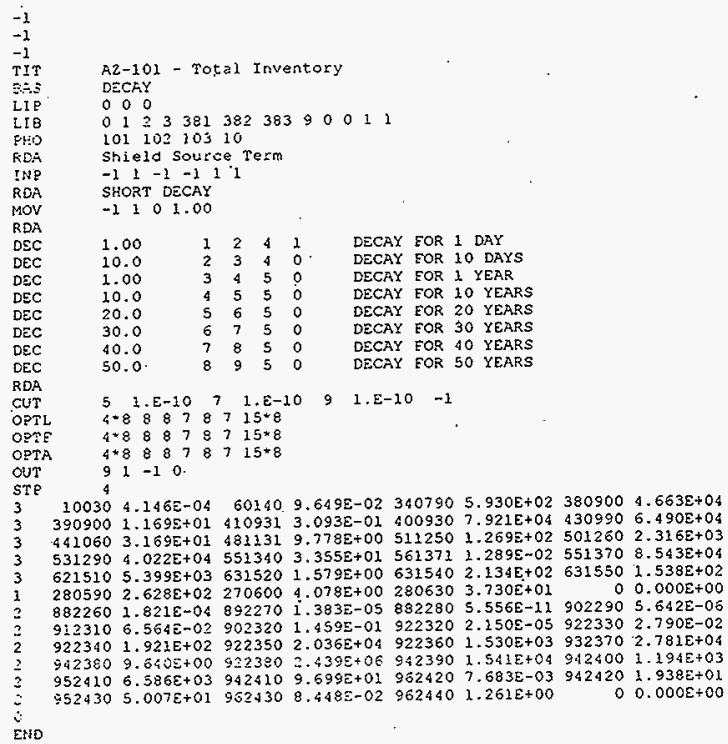


HNF-2110 Rev 0

\section{ENGINEERING ÁNALYSISIDESIGN CALCULATION}

Doc. No. EBU-RCAL-001_Rev

Rev.

Subject: ILAW Shielding Evaluation
Preparer: Anthony Savino
Checker: John McCoy

ate $2 / 5 / 98$

Date 2/5/98

Date $2 / 6 / 98$

APPENDIX C

ISO-PC Input Eile at Time 0 for A2l Phase 1 ranks

\begin{tabular}{|c|c|c|c|}
\hline 2 & & $A N-A I 1 P$ & \\
\hline Rectangular & & Geom & \\
\hline EInput Next= & & Ispects & \\
\hline $\begin{array}{l}\text { Nineta= } 30, \\
\text { SLTH= } 180 .\end{array}$ & & & \\
\hline & & & \\
\hline $\begin{array}{l}T(1)=120 . \\
T(2)=8 .\end{array}$ & & & \\
\hline$x=129$. & & & \\
\hline WEIGHT (451) & $=$ & $3.10 E+04$ & \\
\hline NAEIGHT $\{472\}$ & 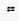 & $9.63 \bar{E}+03$ & \\
\hline WEIGHT ( 27) & $=$ & $1.71 E \div 02$ & \\
\hline HEIGHT ( Q2) & $=$ & $5.125+08$ & \\
\hline MIEIGHT ( 84) & $=$ & $5.12 E+08$ & \\
\hline hEIGHT (102) & $=$ & $9.30 \mathrm{E}+02$ & \\
\hline WEIGHT (103) & $=$ & $5.80 z+02$ & \\
\hline MEIGHT (141) & $=$ & $2.12 \mathrm{E}+04$ & \\
\hline WEIGHT $(270)$ & $=$ & $1.82 \mathrm{E}+05$ & \\
\hline WEIGHT (172) & $=$ & $1.82 \mathrm{E}+05$ & \\
\hline WEIGHT (206) & $=$ & $6.62 \varepsilon+03$ & \\
\hline WEIGHT (269) & $=$ & $2.305+05$ & \\
\hline WEIGHT (270) & $=$ & $6.30 \mathrm{E} \div 02$ & \\
\hline WEIGHT (272) & $=$ & $2.94 \mathrm{E}+02$ & \\
\hline WEIGHT $(274)$ & $=$ & $2.23 E+00$ & \\
\hline WEIGHT $(273)$ & $=$ & $2.94 E+02$ & \\
\hline WEXGHT (290) & $=$ & $3.83 E+01$ & \\
\hline WEIGHT (319) & $=$ & $8.55 E+04$ & \\
\hline HEIGHT (335) & $\approx$ & $2.54 E+07$ & \\
\hline WEIGHT (336) & $=$ & $2.405 \div 07$ & \\
\hline MEIGHT (403) & $=$ & $6.70 \mathrm{E}+05$ & \\
\hline WEIGHT ( 408 ) & $=$ & $5.48 E+02$ & $\therefore$ \\
\hline WEXGHT (415) & $=$ & $9.22 E+04$ & , \\
\hline WEIGHT (418) & $=$ & $1.44 E+05$ & , \\
\hline WEIGHT (332) & $F$ & $6.33 E-05$ & , \\
\hline WEIGHT $(414)$ & $=$ & $4.74 \mathrm{E}-04$ & r. \\
\hline WEIGHT (392) & $=$ & 8. $33 \Xi-06$ & , \\
\hline WEIGHT (482) & $\Rightarrow$ & $2.5 \mathrm{i}=04$ & ' \\
\hline WEIGHT ( 508 ) & $=$ & 3. $8 i \equiv-08$ & ' \\
\hline WEIGHT $\{34\}\}$ & 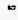 & $6.35 E-05$ & ' \\
\hline WEIGHT (524) & $=$ & $2.32 E-03$ & , \\
\hline WEIGHT (510) & $=$ & $9.11 E-04$ & ' \\
\hline WEIGHT (483) & $=$ & $1.72 E-09$ & , \\
\hline$\therefore=20 \pi 7(337)$ & $=$ & $6.35 E-05$ & , \\
\hline WEIGHT $\{525\}$ & $=$ & $1.32 E-03$ & ， \\
\hline AEIGAT $\{509\}$ & $=$ & $3.86 E=04$ & ， \\
\hline WEIGHT (511) & $=$ & $9.11 \mathrm{E}-04$ & , \\
\hline WEIGHT (5:2) & $=$ & $115-04$ & ' \\
\hline HETGHT (351) & $=$ & $6.35 \mathrm{2}-05$ & , \\
\hline WEIGHT (523) & $=$ & $3.61 \equiv-03$ & , \\
\hline NEIGHT $(514)$ & $=$ & $9.12 E-04$ & , \\
\hline WEIGHT (513) & $=$ & $3.86 \Sigma-04$ & \\
\hline WeIGHE (362) & $=$ & $6.35 E-05$ & r \\
\hline WEIGHT ( 522$)$ & $=$ & $3.61 \mathrm{E}-03$ & \\
\hline WEIGHT (515) & $=$ & $1.13 E-02$ & , \\
\hline WEIGHT $(485\}$ & $\approx$ & $5.505-03$ & \\
\hline WEIGHT (488) & $=$ & $1.065+01$ & \\
\hline
\end{tabular}


HNF-2110 Rev 0

\section{ENGINEERING ANALYSIS/DESIGN CALCULATION}

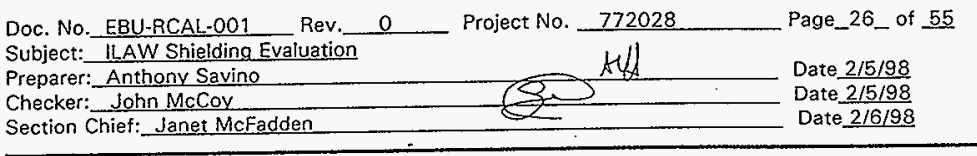

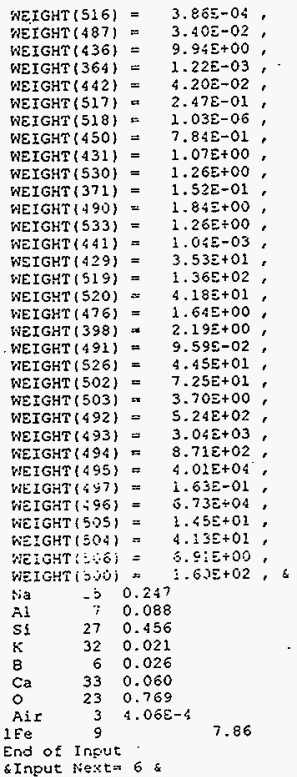


HNF-2110 Rev 0

(a)

\section{ENGINEERING ANALYSIS/DESIGN CALCULATION}

Doc. No. EBU-RCAL-001 Rev

Subject:_ILAW Shielding Evaluation

Preparer: Anthony Savino

Project No. $\quad 772028$

Page_27_ of 55

Checker: John McCoy

Section Chief:_Janet McFadden

Date 2/5/98

Date 2/5/98

Date 2/6/98

\section{ISO-PC Input File at Time o for Tank AZ-101} ILAW - A2-101 Tank - Initial - Cs Reduction Factorm200

Recrangular source Geom - Dose Rate at Surface

E Input Next $=1$, ISpec $=3$, IGeom $=10$, ICONC=0, SEACT $=1$, DUNIT=7,

NTheta $=30$, NPSi= 30, NShld=2, JBuEs 2, OPTION=1,

SLTH 180 .,

$y=120 .$,

$\mathrm{T}(1)=120$,

$\tau(z)=8$.

$X=129$.

WEIGHT $(451)=4.30 E-01$

HEIGHT $(472)=4.61 E+03$

WEIGHT $(27)=4.13 E+01$

WEIGHT $(82)=6.36 E \div 06$

WEIGHT $(84)=6.36 \mathrm{E}+06$

WeIGHT $(102)=1.99 E+02$

NEIGHT $(103)=8.75 \mathrm{E}+01$

NEIGHT $(141)=1.105+03$

WEIGHT $(170)=1.06 \mathrm{E}+05$

WEIGHT $(172)=1.06 \mathrm{E}+0 \mathrm{~S}$

WEIGHT $(206)=2.12 \mathrm{E}+03$.

WEIGHT $(269)=1.31 E+05$.

WEIGHT $(270)=3.58 E+02$

WEIGHT $(272)=6.57 \mathrm{E}+02$

WEIGHT $(274)=5.01 E-01$,

WEIGHT $(273)=6.57 \mathrm{E}+01$

WEIGHT $(290)=7.10 E \div 00$

WEIGHT $(319)=2.20 E+02$

WEIGHT (335) $=3.702+04$

WEIGHT $(336)=3.50 \mathrm{E}+04$.

WEIGHT $(403)=1.42 \mathrm{E}+05$

WEIGHT $(408)=2.73 E+02$

WEIGHT $(415)=5.76 \mathrm{E}+04$,

WEIGHT $(418)=7.25 E+04$,

WEIGHT $(332)=1.86 \mathrm{E}-06$,

WEIGHT $(414)=5.43 E-09$.

WEIGHT $(482)=1.22 E-09$.

WEIGHT (508) = 1.25E-09?

hEIGHT $(34 \mathrm{i})=1.87 \mathrm{E}-06$,

WeIGHr $(524)=1.51 \mathrm{E}-08$

WEIGHT $(510)=2.98 \mathrm{E}-05$

WEIGHT $(483)=5.64 E-11$.

WEIGHT $(337)=1.87 \mathrm{E}-06$.

WEYGHT $(525)=1.51 \mathrm{E}-08$

WEIGHT $(509)=1.87 \mathrm{E}-09$,

WEIGHT $(511)=2.98 \mathrm{E}-05$,

WEIGHT $(522)=2.98 \mathrm{E}-05$.

WEIGHT $(351)=1.87 \mathrm{E}-06$.

WEIGHT $(523)=4.06 \mathrm{E}-08$,

ReIG4T $(514)=2.99 \mathrm{E}-05$.

NEIGHT $(513)=1.87 \varepsilon-09$,

WEIGHT (362) $=1.87 \mathrm{E}-06$.

KETGHT $(522)=4.06 \mathrm{E}-08$.

HEIGHT $(515)=5.495-08$.

WEIGHT $(485)=1.80 \mathrm{E}-04$,

WEIGHT $(516)=1.87 \mathrm{E}-09$,

NEIGHT $(487)=1.00 E-03$

WEIGHT $(364)=3.59 \mathrm{E}-05$.

WEIGHT $(442)=4.57 \mathrm{E}-07$,

WEIGHT $(517)=1.208-06$, 
HNF-2110 Rev 0

(m)

\section{ENGINEERING ANALYSIS/DESIGN CALCULATION}

Doc. No. EBU-RCAL-001 Rev. $\quad 0 \quad$ Project No. 772028
Subject: ILAW Shielding Evaluation
Preparer: Anthony Savino

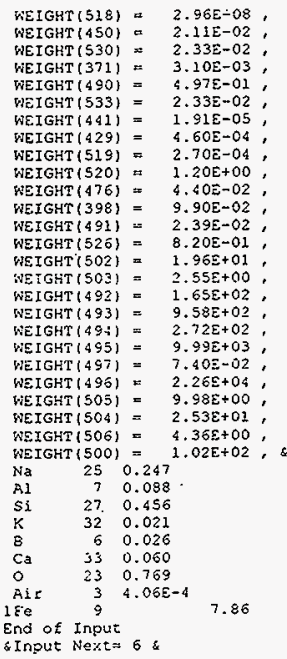


Doc. No. EBU-RCAL-001 Rev Project No. 772028 Page_29_ of $\underline{55}$

Subject: ILAW Shielding Evaluation

Preparer: Anthony Savino

Checker: John McCoy

Section Chief: Janet McFadden

Project No. $\frac{7720}{20}$

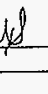

Date $2 / 5 / 98$

Date $2 / 5 / 98$

Date $2 / 6 / 98$

ARPENDIX D

Example ISO-PC Input File to Determine the Dose Rate vs Wall Thickness - Sr90/Y90

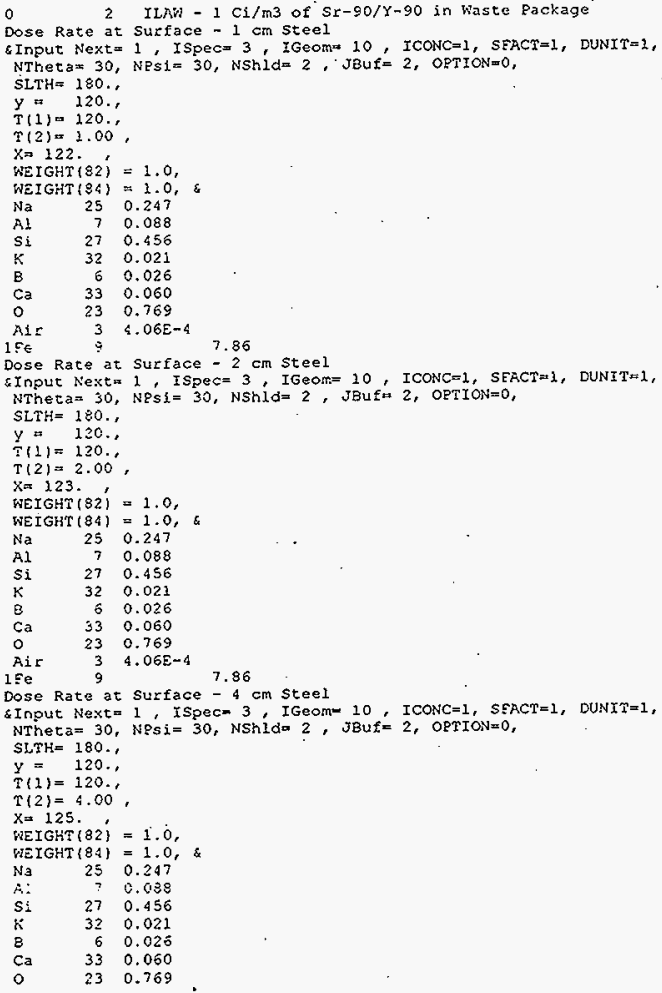


HNF-2110 Rev 0

(ii)

\section{ENGINEERING ANALYSIS/DESIGN CALCULATION}

Doc. No. EBU-RCAL-001 Rev

Subject: ILAW Shielding Evaluation

Preparer: Anthonv Savino

Checker: John McCov

Section Chief: Janet McFadden

Project No. $\quad 772028$

Page_30_ of 55

Date $2 / 5 / 98$

Date $2 / 5 / 98$

Date 2/6/98

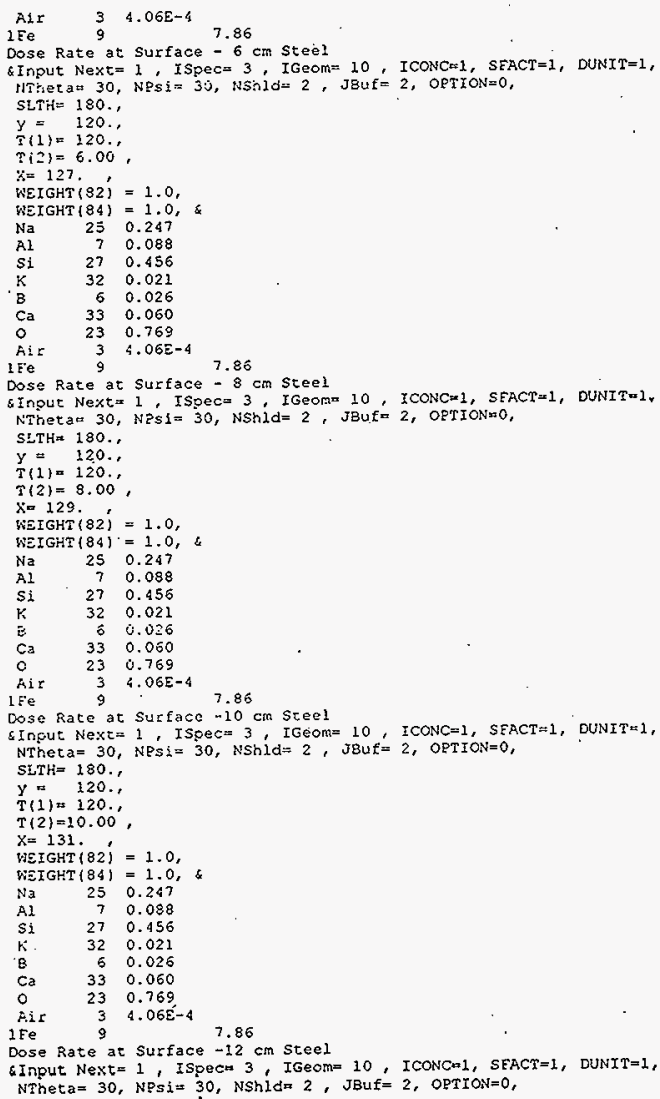


HNF-2110 Rev 0

\section{ENGINEERING ANALYSIS/DESIGN CALCULATION}

Doc. No. EBU-RCAL-001_Rev

Subject: ILAW Shielding Evaluation

Preparer: Anthonx Savino

Project No. 772028

Page_31_of 55

Checker: John McCoy

Date $2 / 5 / 98$

Section Chief: Janet McFadden

Date 2/5/98

Date $\underline{2 / 6 / 98}$

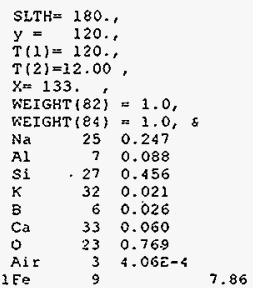

Dose Rate at surface -14 ca steal

sInput Next=1, ISpec= 3, IGeoma 10, ICONCa1, SFAC'=1, DUNIT=1,

NTheraz 30, NRsiz 30, NShlog 2, JBuf= 2, OETION=0,

SLTHe 180 .

$y=120$.

$\mathrm{T}(1)=120$.

$T(2)=14.00$.

$\mathrm{X}=135$.

WEIGHT $(82)=1.0$

WEIGHT $(84)=1.0, s$

Na $25 \quad 0.247$

Al $\quad 7 \quad 0.088$

\$1 $27 \quad 0.456$

h $32 \quad 0.021$

B $\quad 6.0 .026$

Ca $\quad 33 \quad 0.060$

$0 \quad 23 \quad 0.769$

$\begin{array}{llll}\text { Air } & 3 & 4.06 \mathrm{E}-4 & \\ \mathrm{Eee} & 9 & & \end{array}$

Dose Rate at Surface $-16 \mathrm{~cm}$ Steel

\& Input Next $=1$, I Spec= 3 , IGeom 10 , ICONC-1, SFACT $=1$, DUNTT $\mathrm{T}=1$, NTheta $=30$, NPsi= 30, NShid= 2 , JBUL= 2, OPTION=0,

SLTH= 180. ,

$y=120$.

$T(1) \times 120$.

$T\{2\} \neq 16.00$,

$X \times 137$.

WEIGHT $(82 \hat{)}=2.0$,

WEIGHT $(84)=1.0,8$

Na $25 \quad 0.247$

Al $\quad 7 \quad 0.088$

$31 \quad 27 \quad 0.456$

$\begin{array}{lll}K & 32 & 0.021\end{array}$

B $\quad 6 \quad 0.026$

Ca $\quad 33 \quad 0.060$

O $23 \quad 0.769$

A1r $34.06 E-4$

Fe 9.86

Dose Rate at Surface $-28 \mathrm{~cm}$ Steel

Input Noxia 1, ISpeca 3, IGeomm 10, ICONC=1, SEACT\#1, DUNIT=1,

NThet $a=30$, NPsi= 30, NShlda 2, JBuf=2, OPTION=0,

SETH $=180$.

$y=120$.

$T(1)=120 .$.

$T(2)=18.00$,

$\mathrm{X}=139$. 
(II)

HNF-2110 Rev 0

\section{ENGINEERING ANALYSISIDESIGN CALCULATION}

Doc. No. EBU-RCAL-001

Rev.

Project No. 772028

Page_32_ of 55

Subject: ILAW Shielding Evaluation

Preparer: Anthony Savino

A. II

Checker: John McCoy

Date 2/5/98

Section Chief: Janet McFadden

Date 2/5/98

Date $2 / 6 / 98$

\begin{tabular}{|c|c|c|}
\hline WEI & $(84)$ & $=1.0,8$ \\
\hline Na & & \\
\hline Al & 7 & 0.088 \\
\hline \$1 & 27 & 0.456 \\
\hline K & 32 & 0.021 \\
\hline$B$ & 6 & 0.026 \\
\hline $\mathrm{Ca}$ & 33 & 0.060 \\
\hline 0 & 23 & 0.769 \\
\hline $\begin{array}{l}\mathrm{Ar} \boldsymbol{K} \\
\mathrm{Ge}\end{array}$ & 3 & $4.06 E-4$ \\
\hline
\end{tabular}

Dose Rate at surface $-20 \mathrm{~cm}$ steel

EInput Nexta 1, ISpece 3, IGeoms 10, ICONC=1, SEACT=1, DUNIT $=1$,

NTheta=30, NPSi=30, NShid= 2 , JBufa 2 , OPTION=0,

SLTH= 180 .

$y=120$.

$T(1)=120$.

$T(2)=20.00$,

$\mathrm{X}=141$.

WEIGHT $(82)=2.0$

WEIGHT $(84)=3.0$,

$\begin{array}{lll}\mathrm{Na} & 25 & 0.247\end{array}$

Al $\quad 7 \quad 0.088$

Si $27 \quad 0.456$

$\begin{array}{lll}\mathrm{K} & 32 & 0.021\end{array}$

$\begin{array}{lll}\text { B } & 6 & 0.026\end{array}$

Ca $33 \quad 0.060$

$0 \quad 23 \quad 0.769$

Air $34.068-4$

lre 9 A 7.86

Eno of Input

8Inpur Nexta 6 \& 
HNF-2110 Rev 0

\section{ENGINEERING ANALYYSISIDESIGN CALCULATION}

Doc. No. EBU-RCAL-001 Rev. 0 Project No. 772028
Subject: ILAW Shielding Evaluation
Preparer: Anthony Savino
Checker: John McCoy

Example ISO-PC Ingut File to Determine the Dose Rate vs Wall Thlckness - Sn126/Sbl26m/Sbl26 Dose Rate at Surface $-1 \mathrm{~cm}$ steed

\&Input Next $=1$, ISDEC $=3$, IGeOm $=10, I C O N C=1, S F A C T=1$, DUNIT $=1$

NTheta=30, NPSi=30, NShld= $2, J B U f=2$, ORTION=0,

SLTH $=180 .$.

$y=120$.

$T(1)=120$.

$T(2)=1.00$,

$X=122$.

WEIGHT $(272)=1.0$

WEIGHT $(273)=1.0$.

WEIGHT $(274) \times 0.19$,

$\begin{array}{lll}\mathrm{Na} & 25 & 0.247\end{array}$

A. $\quad 7 \quad 0.088$

$\begin{array}{lll}31 & 27 & 0.456\end{array}$

K $\quad 32 \quad 0.021$

B 60.026

ca $\quad 33 \quad 0.060$

$\begin{array}{lll}0 & 23 & 0.769\end{array}$

Ais $\quad 3 \quad 4.06 \mathrm{E}-4,7,86$

Dose Rate at Surface $-2 \mathrm{~cm}$ Steel

\&Input Nextr 1, ISpeca 3, IGeom= 10, ICONC=1, SEACT=1, DUNIT=1, NThetan 30, NPSi=30, NShld $=2$, JBuf $=2$, OPTION=0,

SLTH $=180 .$,

$y=120$.

$T(1)=120$.

$T\{2\}=2.00$

$\mathrm{x}=123$.

WEIGHT $\{272\}=1.0$,

MEIGHT $(273)=1.0$,

WEIGHT $\{274\}=0.14,8$

$\begin{array}{llll}\mathrm{Na} & 25 & 0.247\end{array}$

$\begin{array}{llll}\text { Al } & 7 & 0.088\end{array}$

$\$ 1 \quad 27 \quad 0.456$

$\begin{array}{lll}\times & 32 & 0.021\end{array}$

$\begin{array}{lll}6 & 0.026\end{array}$

Ca $33 \quad 0.060$

$\begin{array}{lll}0 & 23 & 0.769\end{array}$

$\begin{array}{lrll}\text { Air } & 3 & 4.06 E-4 & \\ \text { lFe } & 9 & & 7.86\end{array}$

Dose Rate at Surface $-4 \mathrm{~cm}$ steel

sinput Next $=1$, ISpec $=3$, IGeom $10, I \operatorname{CONC}=1$, SEACT $=1$, DUNIT $=1$,

NThet $a=30, N P S i=30, N S h l d=2, J 8 u f=2$, OerYoN $=0$,

SLTH= $180 .$.

$y=120 .$.

$T(1)=120$.

$T(2)=4.00$.

$X=125$.

AEIGHT $(272)=1.0$

WEIGHT $(273)=1.0$,

WEIGHT $(274)=0.14$,

$\begin{array}{lll}\mathrm{Na} & 25 & 0.247\end{array}$

A. 70.088

$\begin{array}{lll}\text { Si } & 27 & 0.456\end{array}$

$\begin{array}{lll}\mathrm{K} & 32 & 0.021\end{array}$

$\begin{array}{lll}\mathrm{B} & 6 & 0.026\end{array}$

C. 330.060

$\begin{array}{lll}0 & 23 & 0.769\end{array}$ 
HNF-2110 Rev 0

\section{ENGINEERING ANALYSIS/DESIGN CALCULATION}

Doc. No. EBU-BCAL-001 Rev.

Project No. 772028

Page_34_ of 55

Subject: ILAW Shielding Evaluation

Preparer: Anthony Savino

A)

Checker: John McCoy

QSS

Date 2/5/98

Section Chief: Janet McFadden

Date $2 / 5 / 98$

Date $2 / 6 / 98$

$\begin{array}{llll}\text { Air } & 3 & 4.06 \mathrm{E}-4 & \\ \text { iFe } & 9.86 \\ \text { Dose Rate at Surface } & -6 \mathrm{~cm} \text { Steel }\end{array}$

Input Next=1, Ispecr 3, IGeom 10, ICONC=1, SFACT=1, DUNIT=1,

NThetak 30, NESi= 30, NShidm 2, JBuf 2, OPTION=0,

SLTH $=180$. ,

$y=120 .$.

$T(1)=120 .$,

$T(2)=6.00$,

$\mathrm{X}=127$.

WEIGHT $(272)=1.0$

WEIGHT $(273)=1.0$

WEIGHT $(274)=0.14, \&$

$\mathrm{Na} \quad 250.247$

Al 70.088

$\begin{array}{lll}\text { Si } & 27 & 0.456\end{array}$

$\begin{array}{lll}K & 32 & 0.021\end{array}$

$\begin{array}{lll}B & 5 & 0.026\end{array}$

Ca 330.060

$0 \quad$ \%3 0.769

Air 3 4.06E-4

$1 \varepsilon \mathrm{e} \quad 9 \quad 7.86$

Dose Rate at Surface - $8 \mathrm{~cm}$ steel

Input Nexta 1, ISpec= 3, IGeorn 10, ICONC=1, SEACT=1, DUNIT=1,

NTheta $=30, N P s i=30, N S h l d=2$, JBufa 2, OPTION=D,

SLTH $=180$.,

$y=120$.

$T(1)=120$.

$T(2)=8,00$,

$\mathrm{X}=129$.

WEIGHT $(Z>2)=1.0$.

WEIGHT $(273)=1.0$,

WEIGHT $(274)=0,14$,

$\begin{array}{lll}\text { Na } & 25 & 0.247\end{array}$

A. 70.088

Si $\quad 27 \quad 0.456$

K $\quad 32 \quad 0.021$

$\begin{array}{lll}\mathrm{B} & 6 & 0.026\end{array}$

C3 $33 \quad 0.060$

$\begin{array}{lll}0 & 23 & 0.769\end{array}$

Air $34.068-4$

lEe 9 A 9.056

Dose Rate at Surface $-10 \mathrm{~cm} \cdot$ Steel

s Input Next $=1$, ISpec= 3, IGeom= 10, ICONC=1, SEACT=1, DUNIT $=2$,

NTheta $=30$, Nesi=30, NShld $=2$, JBufa 2, OPTIONmO

SLTH $=180$. ,

$y=120 .$,

$T(1)=120$.

$T(2)=10.00$,

$X=131$.

VEIGHT $(272)=1.0$,

WEIGHE $(273)=1.0$,

WEIGHT $(274)=0.14$,

Na $\quad 25 \quad 0.247$

nil $\quad 70.088$

$\begin{array}{lll}31 & 27 & 0.456\end{array}$

K $32 \quad 0.021$

$\begin{array}{lll}\text { B } & 6 & 0.026\end{array}$

$\begin{array}{lll}\mathrm{Ca} & 33 & 0.060\end{array}$

$\begin{array}{lll}\mathrm{Ca} & 23 & 0.769\end{array}$

Ait $\quad 3$ 4.06E-4

$\begin{array}{lll}\text { lEe } & 9 & \end{array}$ 
HNF-2110 Rev 0

(a)

\section{ENGINEERING ANALYSIS/DESIGN CALCULATION}

Doc. No. E8U-RCAL-001 Rev.

Rev. $\quad 0$

Project No. 772028

Page_35_ of $5 \underline{5}$

Subject: ILAW Shielding Evaluation

Preparer: Anthony Savino

HA

Checker: John McCoy

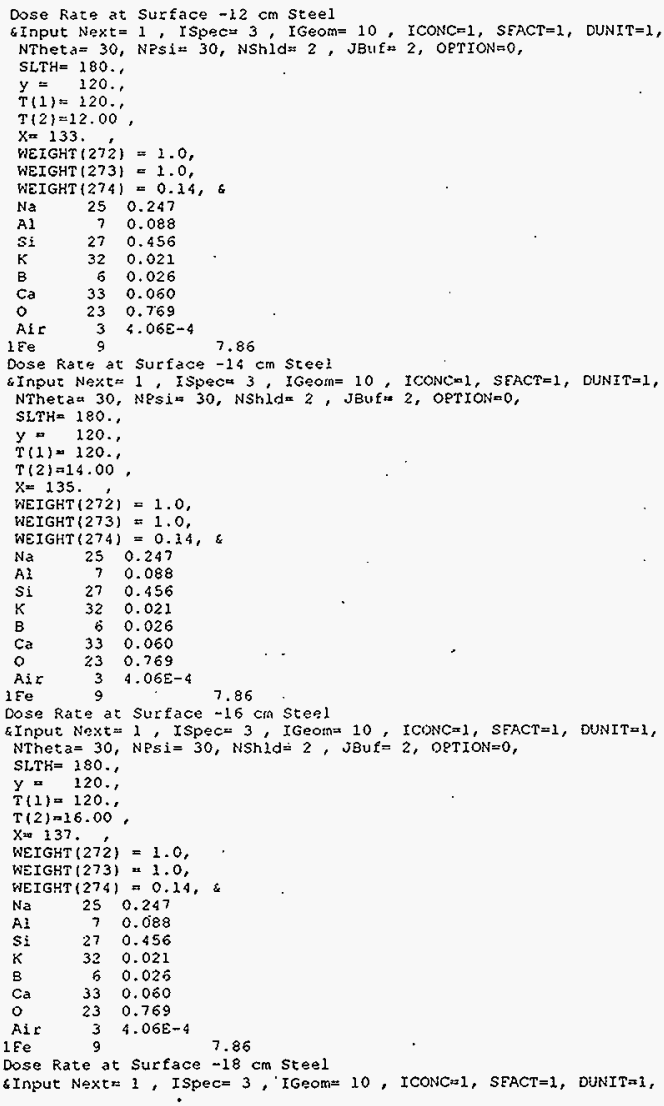


HNF-2110 Rev 0

(2:0

\section{ENGINEERING ANALYSIS/DESIGN CALCULATION}

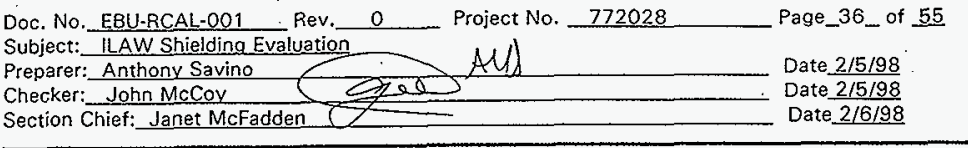

NTheta $=30$, NPsi $=30$, NShld= $2, J B u f=2$, ORTION=0,

SLTH $=180$.

$y=120$.

$T(1)=120$.

$T(2)=18.00$,

$X=139$.

MEIGHT $(272)=1.0$,

WEIGHr (273) = 1.0 ,

WEIGHT $(274)=0.24$,

$\mathrm{Na} \quad 250.247$

Al 70.088

\$1 $27 \quad 0.456$

$\begin{array}{lll}1 & 32 & 0.021\end{array}$

$8 \quad 6 \quad 0.026$

$\begin{array}{lll}\mathrm{Ca} & 33 & 0.060\end{array}$

$\begin{array}{lll}0 & 23 & 0.769\end{array}$

$\begin{array}{llll}\text { Alr } & 3 & 4.06 \mathrm{E}-4 & \\ 1 \mathrm{Fe} & 9 & & 7.86\end{array}$

Dose Rate at Surface $-20 \mathrm{~cm}$ Steel

Envut Next $=1$, ISpec $3, I G e 0 m=10$, rCONCa1, SEACT=1, DUNIT=1

NTheta= 30, NPSi=30, NShid= 2 , JBut $=2$, Oerron $=0$,

SLTH $=180$.

$y=120$. ,

$\tau(1)=120 .$,

$T(z)=20.00$

$\mathrm{X}=141$.

VEIGHT $(272)=1.0$,

WEIGHT $(273)=1.0$,

WEIGHT $(274)=0.14 ;$;

$\begin{array}{lll}\mathrm{Na} & 25 & 0.247\end{array}$

A. 70.088

Si $\quad 27 \quad 0.456$

$\times \quad 32 \quad 0.021$

$\begin{array}{lll}8 & 6 & 0.026\end{array}$

Ca $33 \quad 0.060$

$\begin{array}{lll}0 & 23 & 0.769\end{array}$

Air 3 4.06E-4

1 Fe 9

End of input

anput Next $=6$ \& 
HNF-2110 Rev 0

(u)

\section{ENGINEERING ANALYSIS/DESIGN CALCULATION}

Doc. No. EBU-RCAL-001 Rev. O O Project No. 772028 Subject: LAW Shielding Evaluation Preparer: Anthony Savino AM Checker: John McCoy Section Chief: Janet McFadden Page_37_ of 55

02 ILAW - $1 \mathrm{Cl} / \mathrm{m} 3$ of $\mathrm{Cs}-137 / \mathrm{Ba}-137 \mathrm{~m}$ in Larger Waste Package

Dose Rate at surface - $1 \mathrm{~cm}$ Steel

Input Next=1, I Spec= 3, IGeom= 10, ICONC=1, SEACT=1, DUNIT=1,

NTheta $=30$, NPSi=30, NSnLda $z$, JBuf $=2$, OPTION=0,

SLTh $=200$.,

$y=140 .$.

$T(1)=140 .$,

$T(2)=1.00$.

$\mathrm{x}=142$.

VEIGHT (335) $=1.0$,

WEIGHT $\{336\}=0.946$, \&

$\mathrm{Na} \quad 250.247$

Al $\quad \begin{array}{lll}\text { Al } & 7 & 0.088\end{array}$

$\begin{array}{lll}\text { S1 } & 27 & 0.456\end{array}$

$\begin{array}{lll}\kappa & 32 & 0.021\end{array}$

B 60.026 .

Ca $33 \quad 0.060$

$\begin{array}{lll}0 & 23 & 0.769\end{array}$

Air $34.06 E-4$, 4.86

Dose Rate at Surface $-2 \mathrm{~cm}$ Steel

Input Next= 1. ISpec= 3, IGeoina 10 , ICONC=1, SFACT=1, OUNITa1,

NTheta= 30, NPsi= 30, NShld= 2 , J8ut $=2$, ORTION=0,

SLTH= 200.,

$y=140$.

$T(1)=140$. ,

$\mathrm{T}(2)=2.00$

$\mathrm{X}=143$.

WEIGHT $(335)=1.0$,

HEIGHT $(336)=0.946,6$

Na $25 \quad 0.247$

A) 70.088

S1 $\quad 27 \quad 0.456$

$\begin{array}{lll}K & 32 & 0.021\end{array}$

B $\quad 6 \quad 0.026$

C. $33 \quad 0.060$

O $23 \quad 0.769$

ALE 3 ( $3.058-4$

$1 \mathrm{Ee} \quad 9 \mathrm{gre} \quad 7.86$

Dose Rate at Surface - $4 \mathrm{~cm}$ Steel

\&Input Nexta 1 , x Spec= 3, IGeom 10, ICONC=1, SEACT=1, OUNIT=1,

Niheta $=30$, NPSi $=30$, NShld $=2, J B u f=2$, OPTION=0,

SITH= 200,;

$y=140$.

$T(1)=140 .$,

$T\{2\}=4.00$.

Xn 145.

WEIGHT $\left\{335^{\prime}\right\}=1.0$.

WEIGHT(336) $=0.946$,

$\begin{array}{lll}\mathrm{Na} & 25 & 0.247\end{array}$

Al 70.088

Si $\quad 27 \cdot 0.456$

$\begin{array}{lll}K & 32 & 0.021\end{array}$

B $\quad 6 \quad 0.026$

Ca 330.060

$\begin{array}{lll}0 & 23 & 0.769\end{array}$

Afr $34.06 E-4$ 
HNF-2110 Rev 0

\section{ENGINEERING ANALYSIS/DESIGN CALCULATION}

Doc. No. EBU-RCAL-001 Rev

Rev. 0

Project No, 772028

Page 38 of 55

Subject: ILAW Shielding Evaluation

Preparer: Anthony Savino

Checker: John McCoy

Date $2 / 5 / 98$

Section Chief: Janet McFadden

Date $2 / 5 / 98$

Date $\underline{2 / 6 / 98}$

lEe
Dose Rate at surface -6 ca Steel

GInput Next=1, Ispec= 3, IGeom 10, ICONC=1, SERCT 1 , DUNIT\#1,

NTheta= 30, Nisi= 30, NShid= 2, JBuf=2, OPTION=0,

SLTH= 200,

$\gamma \neq 140$.

$T\{1\}=140 .$,

$T(2)=6.00$

$\mathrm{X}=147$.

WEIGHT $(335)=1.0$,

WEIGHT $(336)=0.946$,

$\begin{array}{lll}\mathrm{Na} & 25 & 0.247\end{array}$

$\begin{array}{lll}\text { A. } & 7 & 0.088\end{array}$

$\begin{array}{lll}\$ 1 & 27 & 0.456\end{array}$

$\begin{array}{lll}K & 32 & 0.021\end{array}$

$\begin{array}{lll}B & 6 & 0.026\end{array}$

Ca $33 \quad 0.060$

$\begin{array}{lll}0 & 23 & 0.769\end{array}$

Air $\quad 3 \quad 4.068-4 \quad 7.86$

Dose Rate ax Surface - $8 \mathrm{~cm}$ steel

anput Next $=1$, I Spec= 3, IGeom 10, ICONC=1, SEACT=1, DUNIT=1, NTheta= 30, NQSi=30, Nshid= $z$, JBuf= 2, OPTroN=0,

SLTH $=200$,

$y=140$.

$T(1)=140$.

$T(2)=8.00$

$\mathrm{X}=149$.

WEIGHT $(335)=1.0$

$\operatorname{WEIGHT}(336)=0.946, \&$

$\mathrm{Na} 25^{\circ} 0.247$

Al $\quad 7 \quad 0.088$

\$1 $27 \quad 0.456$

$\begin{array}{lll}K & 32 & 0.021\end{array}$

B $\quad$ is 0.026

$\begin{array}{lll}\mathrm{Ca} & 33 & 0.060\end{array}$

$\begin{array}{lll}0 & 23 & 0.769\end{array}$

Alr $\quad 3 \quad 4.06 \mathrm{E}-4 \quad 7.86$

Dose Rate at surface $-10 \mathrm{~cm}$ steel

Input Next=1, ISpeca 3, IGeom 10, ICONCr1, SEACT=1, DUNIT=1, NThera $=30, N E S i=30, N S h L d=2,3 B u f=2$, ORTION=0,

SLTH $=200$.,

$y=140$.

$\mathrm{T}(1)=140$. ,

$\tau(2)=10.00$

$\mathrm{X}=151$.

WEIGHT $(335)=1.0$

WEIGHT $(336\}=0.946$, E

Na 250.243

A. 70.088

S1 $27 \quad 0.456$

$\begin{array}{lll}12 & 32 & 0.022\end{array}$

3 $\quad 0.026$

Ca $\quad 33 \quad 0.060$

$\begin{array}{llll}0 & 23 & 0.769\end{array}$

A 1.

15e 9 9 7.86

Dose Rate at Surface -12 ctn steel

6Inpur Next = 1, ISpeca 3, IGeotla $10,100 N C=1, S E A C T=1$, DUNIT $=1$, NThetan 30, NPSi= 30, NShld=2, JBuf $=2$, ORTION=0,

SLTH= 200., 
HNF-2110 Rev 0

\section{ENGINEERING ANALYSIS/DESIGN CALCULATION}

Doc. No. EBU-RCAL-001 ReV.

Subject: LAW Shielding Evaluation

Preparer: Anthony Savino

Project No. 772028

Page_39- of 55

Checker: John McCoy

Date 2/5/98

Section Chief: Janet McFadden

Date 2/5/98

Date $2 / 6 / 98$

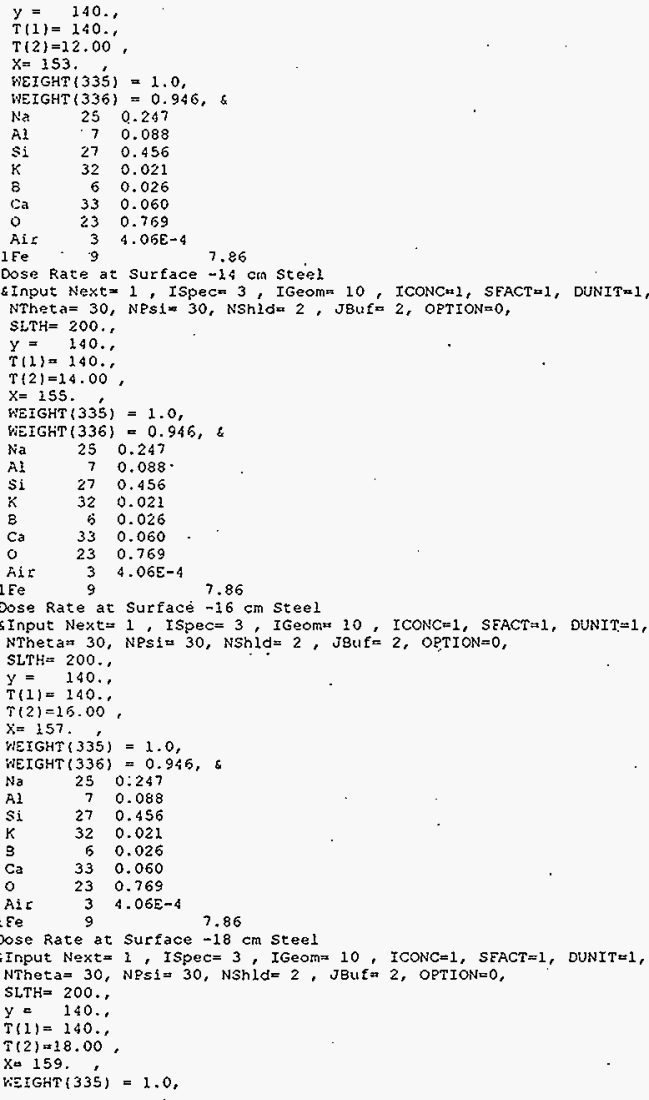


HNF-2110 Rev 0

(8)

\section{ENGINEERING ANALYSIS/DESIGN CALCULATION}

Doc. No. EBU-RCAL-001 Rev.

Project No. $\quad 772028$

Page_40_. of $\underline{55}$

Subject: ILAW Shielding Evaluation

Preparer: Anthony Savino

Checker: John McCoy

Date $2 / 5 / 98$

Section Chief: Janet McFadden

Date 2/5/98

Date 2/6/98

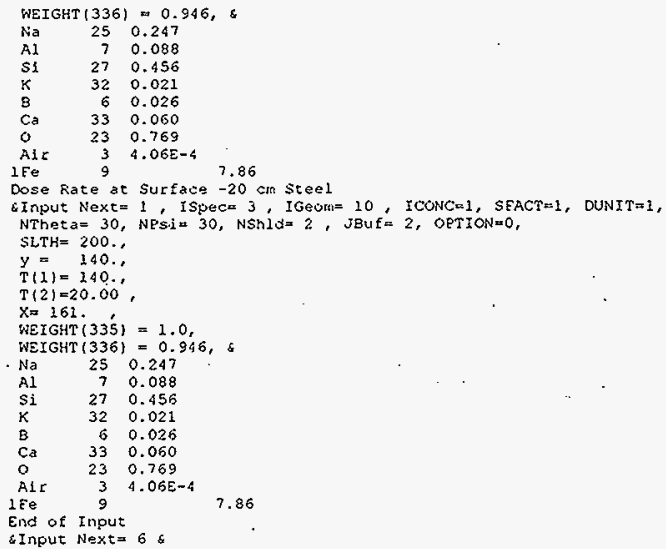


HNF-2110 Rev 0

:

\section{ENGINEERING ANALYSIS/DESIGN CALCULATION}

Doc. No. EBU-RCAL-001 ... Rev Subject: ILAW Shielding Evaluation

Preparer: Anthony Savino

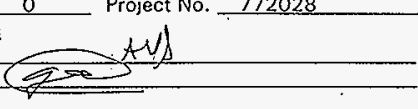

Page_41_of $\underline{55}$

Checker: John McCoy

Date_2/5/98

Section Chief: Janet McFadden

Date 2/5/98

Date $2 / 6 / 98$

\section{APRENDIX $\varepsilon$}

Spreadsheet Showing Bercent Differences Between Calculated and Eitted Dose Rates

$1 \mathrm{c} / \mathrm{m} 3$ of co-60 in Waste Package

Poly Regression: $\quad 0.075 \quad-0.1970 .000654$

$\begin{array}{cccc}\text { cm } & \begin{array}{c}\text { Calc'd } \\ \text { rem/h }\end{array} & \begin{array}{c}\text { Poly-Eit } \\ \text { ren } / \mathrm{h}\end{array} & \begin{array}{r}\text { Poly-Eit } \\ \text { 8diff }\end{array} \\ 1 & 0.7883 & 0.75623 & 4.07 \\ 2 & 0.4779 & 0.482632 & -0.99 \\ 4 & 0.1915 & 0.198365 & -3.53 \\ 6 & 0.08035 & 0.082517 & -2.70 \\ 8 & 0.03437 & 0.034742 & -1.08 \\ 10 & 0.01487 & 0.014805 & 0.44 \\ 12 & 0.006483 & 0.006385 & 1.51 \\ 14 & 0.002841 & 0.002787 & 1.89 \\ 16 & 0.001249 & 0.001231 & 1.40 \\ 18 & 0.000551 & 0.000551 & 0.10 \\ 20 & 0.000244 & 0.000249 & -2.27\end{array}$

$1 \mathrm{Cl} / \mathrm{m} 3$ of $\mathrm{Sr}-90 / \mathrm{y}-90$

foly Regression: $-2.774 \quad-0.279 \quad 0.00313$

cm $\begin{array}{cccr}\text { Calc'd } & \text { Eoly-Elt } \\ \text { rem/h } & \text { Rely-Fit } \\ \text { rem/h } & \text { 3diff } \\ 1 & 0.001014 & 0.000892 & 12.08 \\ 2 & 0.00047 & 0.000479 & -1.89 \\ 4 & 0.000131 & 0.000145 & -10.28 \\ 6 & 4.26 E-05 & 4.62 E-05 & -8.49 \\ 8 & 1.51 E-05 & 1.56 E-05 & -3.73 \\ 10 & 5.67 E-06 & 5.61 E-06 & 1.20 \\ 12 & 2.24 E-06 & 2.13 E-06 & 4.67 \\ 19 & 9.14 E-07 & 8.58 E-07 & 6.16 \\ 16 & 3.85 E-07 & 3.66 E-07 & 5.05 \\ 18 & 1.66 E-07 & 1.65 E-07 & 0.70 \\ 20 & 7.34 E-08 & 7.91 E-08 & -7.71\end{array}$


HNF-2110 Rev 0

(ii)

\section{ENGINEERING ANALYSIS/DESIGN CALCULATION}

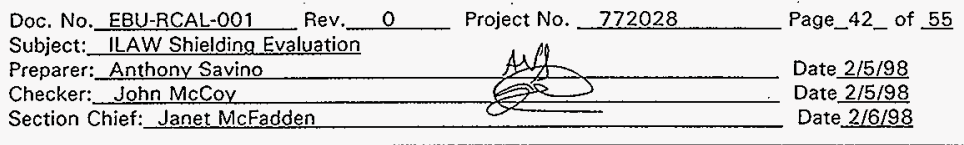

$1 \mathrm{Cl} / \mathrm{m} 3$ of $\mathrm{Ru}-106 / \mathrm{Rh}-106$

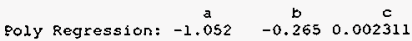

am $\begin{array}{rrrr}\text { Calc'd } & \text { Poly-Eit roly-Eit } \\ \text { rem/h } & \begin{array}{c}\text { rem/h } \\ \text { sdift }\end{array} \\ 1 & 0.05098 & 0.048452 & 4.96 \\ 2 & 0.0266 & 0.026745 & -0.55 \\ 4 & 0.008138 & 0.008413 & -3.39 \\ 6 & 0.002699 & 0.002762 & -2.71 \\ 8 & 0.000937 & 0.000946 & -1.02 \\ 10 & 0.000341 & 0.000338 & 0.93 \\ 12 & 0.00013 & 0.000126 & 2.61 \\ 14 & 5.09 E-05 & 4.91 E-05 & 3.58 \\ 16 & 2.07 E-05 & 1.99 E-05 & 3.51 \\ 18 & 8.61 E-06 & 8.45 E-06 & 1.92 \\ 20 & 3.67 E-06 & 3.74 E-06 & -1.69\end{array}$

$1 \mathrm{Ci} / \mathrm{m}^{3}$ of $\mathrm{Sb}-125$

Poly Regression: $-0.807 \quad-0.2840 .001031$

cm $\begin{array}{cccr}\text { Calc's } & \begin{array}{c}\text { Poly-F1t } \\ \text { rem/h } \\ \text { rem/h }\end{array} & \begin{array}{r}\text { Foly-Fit } \\ 8 d i f f\end{array} \\ 1 & 0.08555 & 0.081289 & 4.98 \\ 2 & 0.0422 & 0.042572 & -0.88 \\ 4 & 0.01142 & 0.011844 & -3.71 \\ 6 & 0.003271 & 0.003358 & -2.67 \\ 8 & 0.000963 & 0.00097 & -0.73 \\ 10 & 0.000289 & 0.000286 & 1.13 \\ 12 & 8.79 E-05 & 8.58 \varepsilon-05 & 2.43 \\ 14 & 2.7 E-05 & 2.62 E-05 & 2.93 \\ 16 & 8.39 E-06 & 8.18 E-06 & 2.50 \\ 18 & 2.63 E-06 & 2.65-06 & 0.94 \\ 20 & 8.26 E-07 & 8.425-07 & -1.95\end{array}$


HNF-2110 Rev 0

(2)

\section{ENGINEERING ANALYSIS/DESIGN CALCULATION}

Doc. No. EBU-RCAL-001 Rev. 0 Project No. 772028

Page_43_ of $\underline{55}$

Subject: LLW Shielding Evaluation

Preparer: Anthony Savino

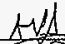

Checker: John McCoy

Section Chief: Janet McFadden

$1 \mathrm{Cl} / \mathrm{m}^{3}$ of $\mathrm{Sn}-126 / \mathrm{Sb}-126 \mathrm{~m} / \mathrm{Sb}-126$

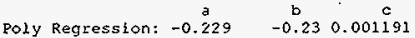

$\begin{array}{cccc}c m & \begin{array}{c}\text { Calc'd } \\ \text { rem/h }\end{array} & \begin{array}{c}\text { Foly-Fit } \\ \text { rem/h }\end{array} & \begin{array}{c}\text { Poly-Eit } \\ \text { Zdiff }\end{array} \\ 1 & 0.3637 & 0.348491 & 4.18 \\ 2 & 0.2046 & 0.206902 & -1.12 \\ 4 & 0.07148 & 0.074141 & -3.72 \\ 6 & 0.02638 & 0.027157 & -2.94 \\ 8 & 0.01003 & 0.010168 & -1.37 \\ 10 & 0.003895 & 0.003891 & 0.09 \\ 12 & 0.001538 & 0.001522 & 1.02 \\ 14 & 0.000617 & 0.000609 & 1.27 \\ 16 & 0.000251 & 0.000249 & 0.71 \\ 18 & 0.000103 & 0.000104 & -0.74 \\ 20 & 4.38-05 & 4.44 \mathrm{E}-05 & -3.19\end{array}$

$1 \mathrm{Ci} / \mathrm{m} 3$ of $\mathrm{Cs}-134$

Poly Regression: $\begin{array}{cccc}a & 0.28 & -0.252 & 0.001292\end{array}$

\begin{tabular}{|c|c|c|c|}
\hline & Calced & Eody-Eit & 8oly-Eit \\
\hline $\mathrm{cm}$ & rem/h & rem/h & $\begin{array}{r}\text { Bdift } \\
3.83\end{array}$ \\
\hline 2 & 0.2072 & 0.209492 & -1.11 \\
\hline 4 & 0.0659 & 0.068026 & -3.2 \\
\hline 6 & 0.02211 & 0.022621 & -2.31 \\
\hline & 0.007643 & 0.007703 & -0.79 \\
\hline 10 & 0.0027 & 0.002687 & 0.50 \\
\hline 12 & 0.000972 & 0.00096 & 1.31 \\
\hline 14 & 0.000356 & 0.000351 & 1.5 \\
\hline 16 & 0.000133 & 0.0001 & 11 \\
\hline 18 & 5.04 & $5.04 E-05$ & \\
\hline & & & \\
\hline
\end{tabular}


HNF-2110 Rev 0

im

\section{ENGINEERING ANALYSIS/DESIGN CALCULATION}

Doc. No. EBU-RCAL-001 Rev

Rev. 0

Project No. 772028

Page_44_of $\underline{55}$

Subject: JLAW Shielding Evaluation

Preparer: Anthony Savino

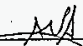

Date 2/5/98

Checker: John McCoy

Date. 2/5/98

Section Chief: Janet McFadden

$1 \mathrm{Ci} / \mathrm{m} 3$ of $\mathrm{Cs}-137 / \mathrm{Ba}-137 \mathrm{~m}$

Poly Regression: $\begin{array}{cccc} & -0.631 & b & c \\ & -0.258 & 0.000641\end{array}$

\begin{tabular}{|c|c|c|c|}
\hline cra & $\begin{array}{c}\text { calc'd } \\
\text { rem/h }\end{array}$ & $\begin{array}{c}\text { Poly-Fit } \\
\text { rem/h }\end{array}$ & $\begin{array}{l}\text { Poly-git } \\
\text { sodiff }\end{array}$ \\
\hline 1 & 0.1349 & 0.129313 & 4.1 \\
\hline 2 & 0.07095 & 0.071708 & -1 . \\
\hline 4 & 0.02149 & 0.022247 & -3 \\
\hline 6 & 0.006802 & 0.006984 & -2 \\
\hline 8 & 0.002194 & 0.002218 & -1 . \\
\hline 10 & 0.000715 & 0.000713 & \\
\hline 12 & 0.000235 & 0.000232 & \\
\hline 14 & $7.75 E-05$ & $7.63 E-05$ & \\
\hline 16 & $2.56 \mathrm{E}-05$ & $2.54 \varepsilon-0.5$ & \\
\hline 18 & $8.52 E-06$ & $8.57 \varepsilon-06$ & \\
\hline & & & \\
\hline
\end{tabular}

$1 \mathrm{Ci} / \mathrm{m}^{3}$ of $\mathrm{Eu}-152$

goly Regression: $-0.327 \quad-0.2120 .001104$

cm $\begin{array}{cccr}\text { Calcid } & \text { Poly-Fit } & \text { Poly-Fit } \\ \text { rem/h } & \text { rem/h } & \text { 8diff } \\ 1 & 0.306 & 0.289804 & 5.29 \\ 2 & 0.1772 & 0.179234 & -1.15 \\ 4 & 0.06647 & 0.069609 & -4.72 \\ 6 & 0.02655 & 0.02759 & -3.92 \\ 8 & 0.01095 & 0.01116 & -1.92 \\ 10 & 0.004612 & 0.004607 & 0.11 \\ 12 & 0.001971 & 0.001941 & 1.53 \\ 14 & 0.000851 & 0.000834 & 1.99 \\ 16 & 0.000371 & 0.000366 & 1.37 \\ 18 & 0.000163 & 0.000164 & -0.52 \\ 20 & 7.215-05 & 7.495-05 & -3.87\end{array}$


HNF-2110 Rev 0

입

\section{ENGINEERING ANALYSIS/DESIGN CALCULATION}

Doc. No. EBU-RCAL-001 Rev. 0 Project No. 772028 Page_45_of 55

Subject: ILAW Shielding Evaluation Preparer: Anthony Savino

Checker: John McCoy Section Chief: Janet McFadden

$1 \mathrm{Ci} / \mathrm{m} 3$ of $\mathrm{Eu}-154$

Poly Regression: $\quad-0.27 \quad-0.213 \quad 0.001048$

an $\begin{array}{cccc}\text { Calc'd } & \text { Poly-Eit Eoly-Eit } \\ \text { rem/h } & \text { rem } / h & \text { sdiff } \\ 1 & 0.3464 & 0.329646 & 4.84 \\ 2 & 0.2016 & 0.203326 & -0.86 \\ 4 & 0.07567 & 0.078482 & -3.72 \\ 6 & 0.03002 & 0.030884 & -2.88 \\ 8 & 0.01226 & 0.01239 & -1.06 \\ 10 & 0.005105 & 0.005068 & 0.73 \\ 12 & 0.002157 & 0.002113 & 2.04 \\ 14 & 0.000922 & 0.000398 & 2.54 \\ 16 & 0.000398 & 0.000389 & 2.11 \\ 18 & 0.000173 & 0.000172 & 0.63 \\ 20 & 7.595-05 & 7.758-05 & -2.15\end{array}$

$\square$ 
HNF-2110 Rev 0

\section{ENGINEERING ANALYSIS/DESIGN CALCULATION}

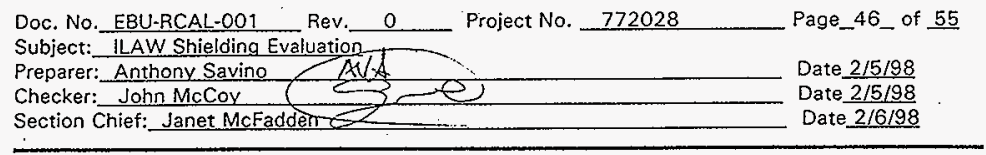

\section{APPENDIX F \\ Justification for Use of ISO-PC Version 2.1 for this Application}

As mentioned in Section 2.0, ISO-PC Version 2.1 has not gone through the verification and validation (V\&V) process required by the WMNW Quality Assurance Program at this time. This appendix provides justification for use of ISO-PC Version 2.1 for the applications in this report.

The ISO-PC computer code was used for this application due to its speed, ease of use, and the simplicity of the geometry of the ILAW package. Because of the number of separate cases that had to be run for this analysis, the ISO-PC computer code was preferred over the slower and more cumbersome monte carlo computer programs. The ISO-PC Version 2.1 computer code is a derivative of the ISOSHLD-PC computer code which has had extensive use at the Hanford Site over the years, and has gone through a V\&V process similar to that required by the WMNW QA program (Lourant 1989). In order to validate it's use for this application, a series of benchmark cases were run using the MCNP Version 4A (Breismeister, J. F., 1993, and Carter, L. L., 1995) monte carlo computer code. MCNP Version 4A has gone through the WMNW $V \& V$ process.

Three cases were run in MNCP to assess the adequacy of the ISO-PC results for the current application. The first case was for the nominal configuration of the ILAW waste package, which consists of a rectangular steel box $1.2 \mathrm{~m}$ tall $\times 1.2 \mathrm{~m}$ wide $\times 1.8 \mathrm{~m}$ long with a total wall thickness of $8 \mathrm{~cm}$ of steel, was modeled in MCNP. The geometry and material composition used in both MCNP and ISO-PC were the same. The source term (photon emission rate) used in MCNP was taken from the ORIGEN outputs discussed in Section 2.0 for the Phase 1 tank inventory. Cases 2 and 3 were for a $1 \mathrm{Ci} / \mathrm{m}^{3}$ activity loading of $\mathrm{Cs} 137$ with total wall thicknesses of $2 \mathrm{~cm}$ and $18 \mathrm{~cm}$, respectively. The MCNP input files are included at the end of this appendix.

The results obtained from ISO-PC and MCNP for these three cases are shown below. The ISO-PC results for Cases 2 and 3 were taken from Table 4 on page 17 of this report. The ISO-PC dose rate for Case 1 was obtained from the output of the ISO-PC model described in Section 2 and listed in Appendix C.

\begin{tabular}{|c|c|c|c|}
\hline \multicolumn{3}{|c|}{ Surface Dose Rate, mrem/h } & \multirow[b]{2}{*}{ Description } \\
\hline & ISO-PC & MCNP & \\
\hline Case 1 & $3.80 \mathrm{e} 6$ & $3.96 \mathrm{E} 6$ & $\begin{array}{l}\text { Phase } 1 \text { Tank Inventory } \\
\text { (Cs reduced by factor of } 200), 8 \mathrm{~cm} \text { steel }\end{array}$ \\
\hline Case 2 & 71 & 72 & $1 \mathrm{Ci} / \mathrm{m}^{3}$ of $\mathrm{Cs} 137,2 \mathrm{~cm}$ steel \\
\hline Case 3 & 0.00852 & 0.010 & $1 \mathrm{Ci} / \mathrm{m}^{3}$ of $\mathrm{Cs} 137,18 \mathrm{~cm}$ steel \\
\hline
\end{tabular}




\section{HNF-2110 Rev 0}

\section{ENGINEERING ANALYSIS/DESIGN CALCULATION}

Doc. No. EBU-RCAL-001

Rev

Project No. $\quad 772028$

Page_47_of 55

Subject: ILAW Shielding Evaluation

Preparer: Anthony Savino

AN

Date 2/5/98

Checker: John McCoy

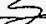

Date 2/5/98

Section Chief: Janet McFadden

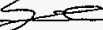

Date 2/6/98

These three cases adequately demonstrate that ISO-PC provides results that are consistent with the more rigorous and computationally accurate MCNP code. The two computer codes use completely different computational methods, with ISO-PC using the point kernel method, and MCNP using the more sophisticated monte carlo method. Both çodes produced consistent results for a wide range of wall thicknesses $(2,8,18 \mathrm{~cm}$ of steel), and for a single isotope (Cs137) as well as a large group of isotopes (Phase 1 tank inventory from Table 1).

It is concluded that ISO-PC yields acceptably accurate results for the shielding configurations and source terms addressed in this report.

\section{References}

Breismeister, J. F., Editor, 1993, MCNP--A General Monte Carlo Code N-Particle Transport Code, Version 4a, LA-12625, Los Alamos National Laboratory, Los Alamos, New Mexico.

Carter, L. L., 1995, Certification of MCNP. Version 4 A for WHC Computer Platforms, WHC-SD-MPSWD-30001, Rev. 7, ECN 605701, Westinghouse Hanford Company, Richland, Washington.

Lourant, I; 1989, Validation of ISOSHLD-PC on the IBM-PC, WHC-SD-SOA-CSWD-303, Rev 0 , Westinghouse Hanford Company, Richland, Washington. 
HNF-2110 Rev 0

(ii)

\section{ENGINEERING ANALYSIS/DESIGN CALCULATION}

Doc. No. $\frac{\text { EBU-RCAL-O01 }}{\text { ILAW Shielding Evaluation }}$ Rev. 0 Project No. 772028

Preparer: Anthony Savino

AUh

Checker: John McCoy

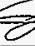

Section Chief: Janet McFadden

Date 2/5/98

Date 2/6/98

MCNR Input File for Case 1 - Phase 1 Tank Inventory with 8 cm steel

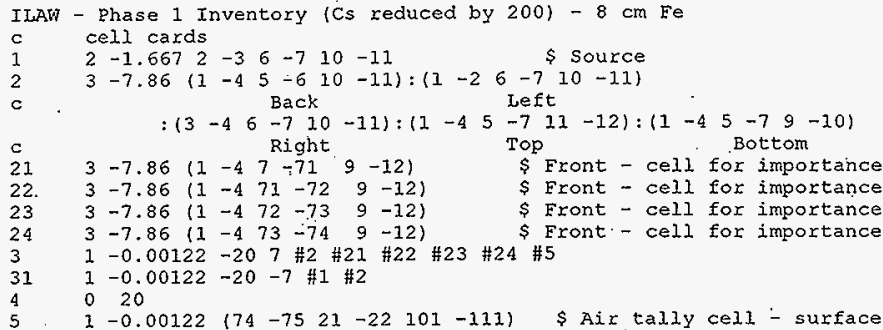

$\begin{array}{llr}c & \text { surface } \\ 1 & \mathrm{px} & -92 \\ 2 & \mathrm{px} & -90 \\ 21 & \mathrm{px} & -15 \\ 22 & \mathrm{px} & 15 \\ 3 & \mathrm{px} & 90 \\ 4 & \mathrm{px} & 92 \\ 5 & \mathrm{py} & -62 \\ 6 & \mathrm{py} & -60 \\ 7 & \mathrm{py} & 60 \\ 71 & \mathrm{py} & 62 \\ 72 & \mathrm{py} & 64 \\ 73 & \mathrm{py} & 66 \\ 74 & \mathrm{py} & 68 \\ 75 & \mathrm{py} & 70 \\ 9 & \mathrm{pz} & -62 \\ 10 & \mathrm{pz} & -60 \\ 101 & \mathrm{pz} & -15 \\ 111 & \mathrm{pz} & 15 \\ 11 & \mathrm{pz} & 60 \\ 12 & \mathrm{pz} & 62 \\ 20 & \mathrm{so} & 300 \\ & & \end{array}$

mode $\mathrm{p}$

$\$$ photon

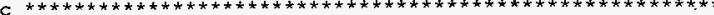

C SOURCE - Phase 1 Inventory with Cs Reduced by 200

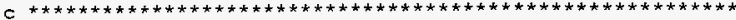

sdef $\quad \operatorname{cel}=1$ pos $=0$ o 0 wgt $=2.316 \mathrm{e} 18$ erg $=\mathrm{d} 4$

. $x=d 1 \quad y=d 2 \quad z=d 3$

scl $x$ extent

sil $-90 \quad 90$ 
HNF-2110 Rev 0

ENGINEERING ANALYSIS/DESIGN CALCULATION

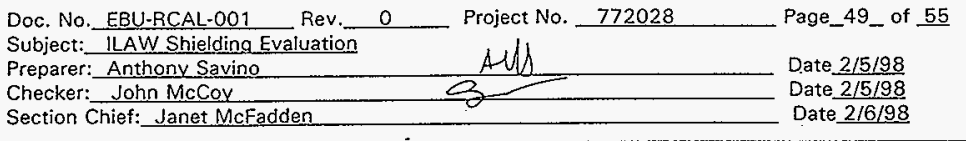

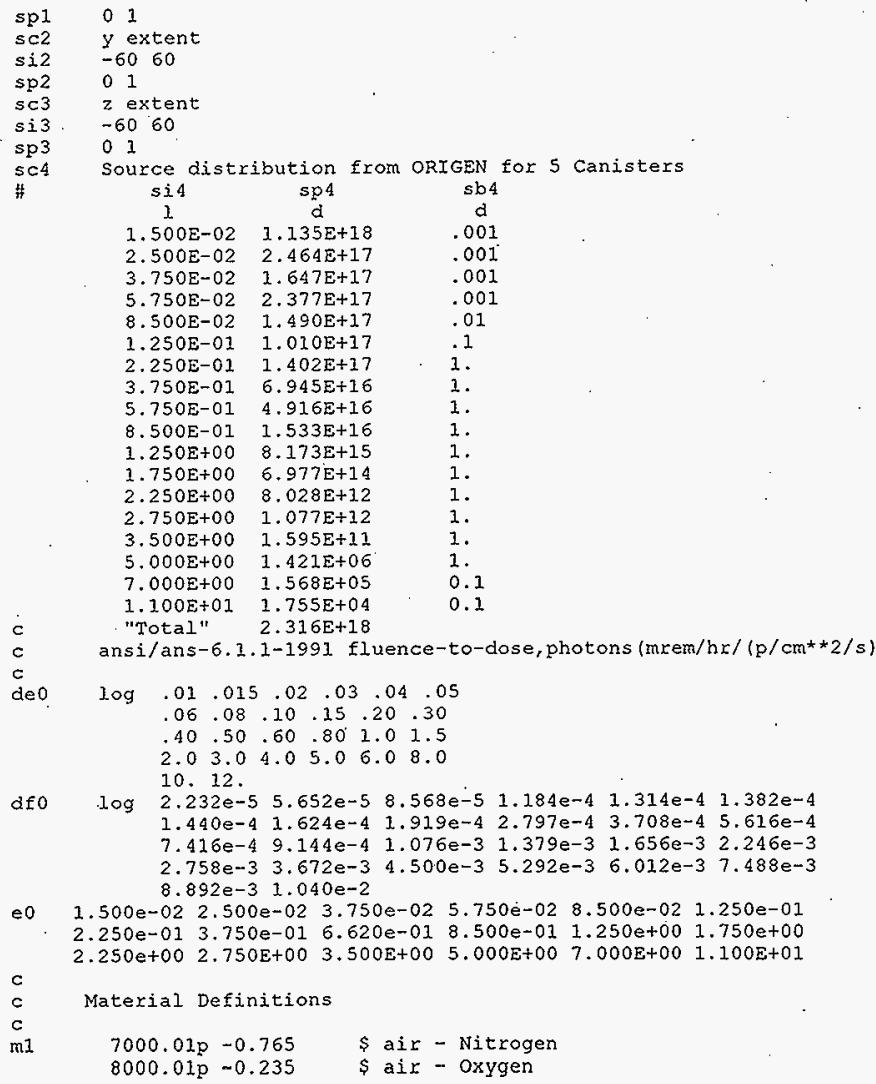


HNF-2110 Rev 0

(iv)

\section{ENGINEERING ANALYSISIDESIGN CALCULATION}

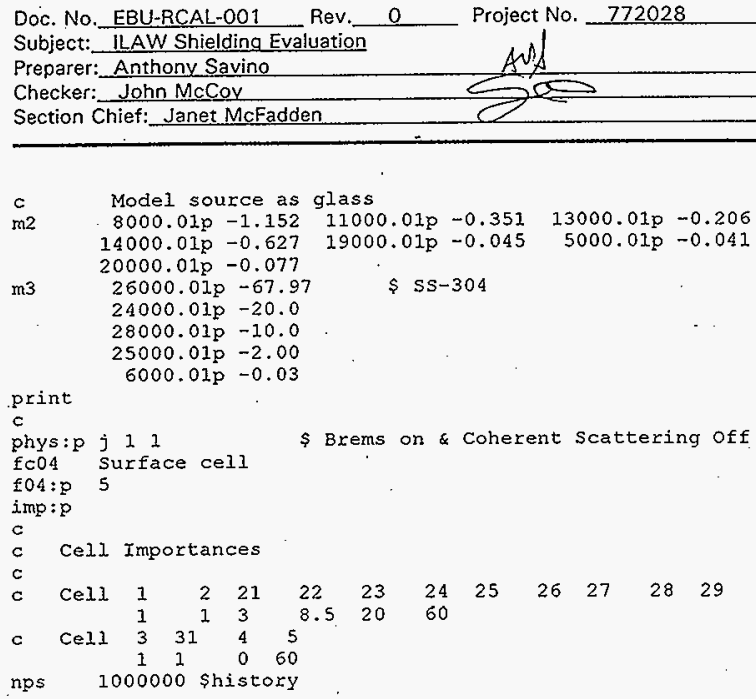


HNF-2110 Rev 0

(20)

\section{ENGINEERING ANALYSIS/DESIGN CALCULATION}

Doc. No. EBU-RCAL-001 Rev Subject: ILAW Shielding Evaluation Preparer: Anthony Savino Checker: John McCoy Section Chief: Janet McFadden Project No. 772028 Page_51_ of 55

\section{MCNP Input File for Case $2-I \mathrm{Ci} / \mathrm{m} 3$ of $\mathrm{Cs} 137$ with $2 \mathrm{~cm}$ steel}

ILAW with shipping Container - Cs-1371 Ci/m3 (2.592 Ci total) - $2 \mathrm{~cm} F \mathrm{~F}$ c cell cards

$\begin{array}{llllllllll}1 & 2 & -1.667 & 2 & -3 & 6 & -7 & 10 & -11\end{array}$ 
HNF-2110 Rev 0

\section{ENGINEERING ANALYSIS/DESIGN CALCULATION}

Doc. No. EBU-RCAL-001 Rev. 0
Subject: ILAW Shielding Evaluation
Preparer: Anthony Savino

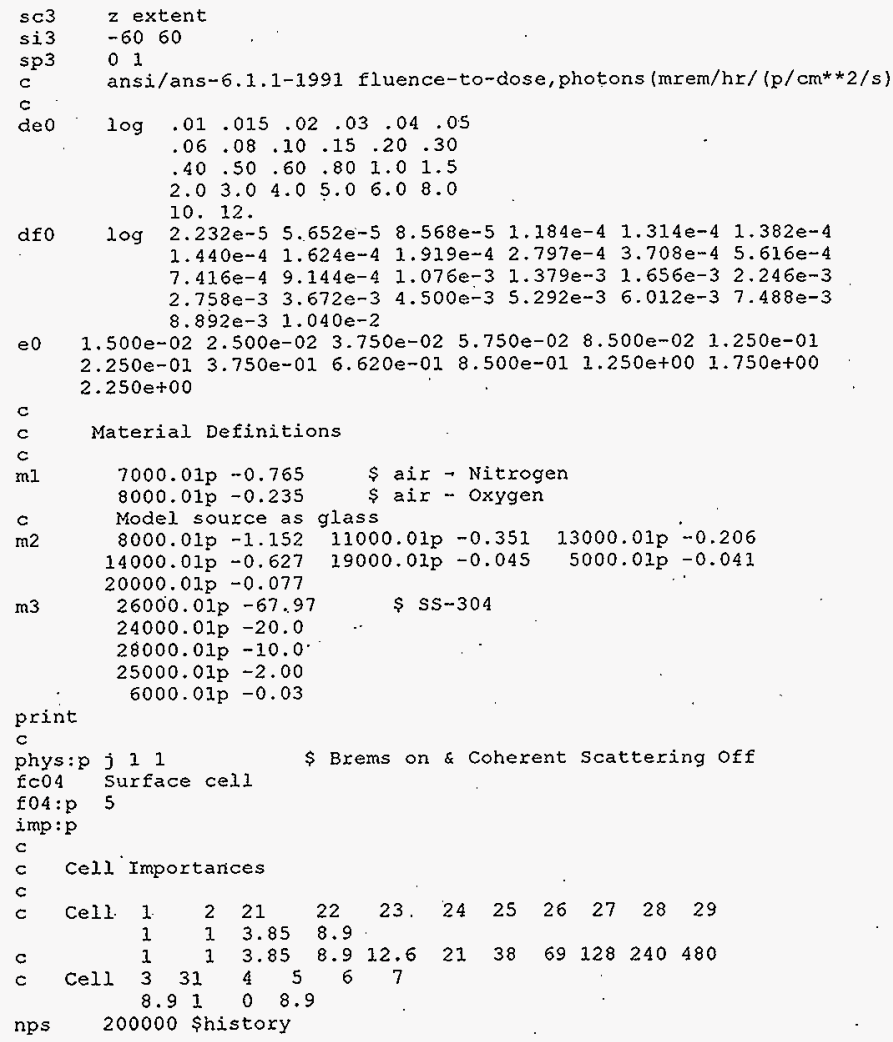


HNF-2110 Rev 0

\section{ENGINEERING ANALYSIS/DESIGN CALCULATION}

Doc. No. EBU-RCAL-001 Rev. Subject: ILAW Shielding Evaluation Preparer: Anthony Savino

Checker: John McCoy

Section Chief: Janet McFadden _....._

Project No. 772028

Page_53_of 55

Date 2/5/98

Date 2/5/98

Date $\underline{2 / 6 / 98}$

MCNF Input File for Case $2-1 \mathrm{Cj} / \mathrm{m} 3 \mathrm{Cs} 137$ with $18 \mathrm{~cm}$ steel

ILAW with Shipping Container - Cs-137 $1 \mathrm{Cj} / \mathrm{m} 3(2.592 \mathrm{Ci}$ total) - $18 \mathrm{cra} \mathrm{Fe}$ c cell cards

$1 \quad 2-1.6672-3 \quad 6-7 \quad 10-11$

s souxce

$3-7.86(1-45-6 \cdot 10-11):(1-2 \quad 6-7 \quad 10-11)$

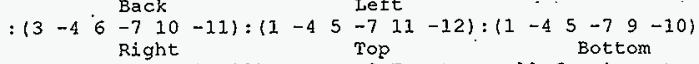

$21 \quad 3-7.86\left(\begin{array}{llllll}1 & -4 & 7 & -71 & 9 & -12\end{array}\right)$

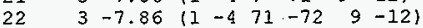

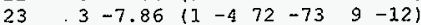

$24 \quad 3-7.86(1)-4 \quad 73-74 \quad 9-12)$

$\left.\begin{array}{lllllllll}25 & 3 & -7.86 & (1 & -4 & 74 & -75 & 9 & -12\end{array}\right)$

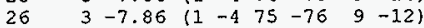

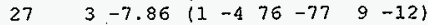

$\left.\begin{array}{lllllllll}28 & 3 & -7.86 & (1 & -4 & 77 & -78 & 9 & -12\end{array}\right)$

$29 \quad 3-7.86\left(\begin{array}{lllllll}1 & -4 & 78 & -79 & 9 & -12\end{array}\right)$

3

31

$1-0.00122-207$ \#2 \#21 \#22

$0.00122-20-7$ \#1 \#2

$4 \quad 0 \quad 20$

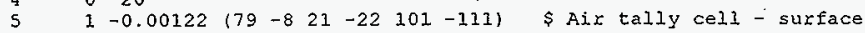

c surface cards

$1 \quad p x-92$

$2 \quad \mathrm{px}-90$

$21 \mathrm{px}-15$

$22 \mathrm{px} \quad 15$

$3 \mathrm{px} 90$

4 px 92

5. py -62

6 py -60

7 py 60

71 py 62

72 py 64

73 py 66

74 py 68

75 py 70

76 py 72

77 py 74

78 py 76

79 py 78

8 py 80

9 pz -62

10 pz -60

101 pz -15

111 pz 15

11 pz 60

12 pz 62 
HNF-2110 Rev 0

(a)

\section{ENGINEERING ANALYSISIDESIGN CALCULATION}

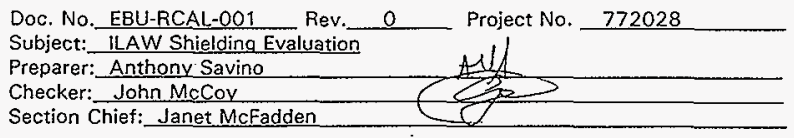

Page_54_of $\underline{55}$

Date 2/5/98

Date $2 / 5 / 98$

Date $2 / 6 / 98$

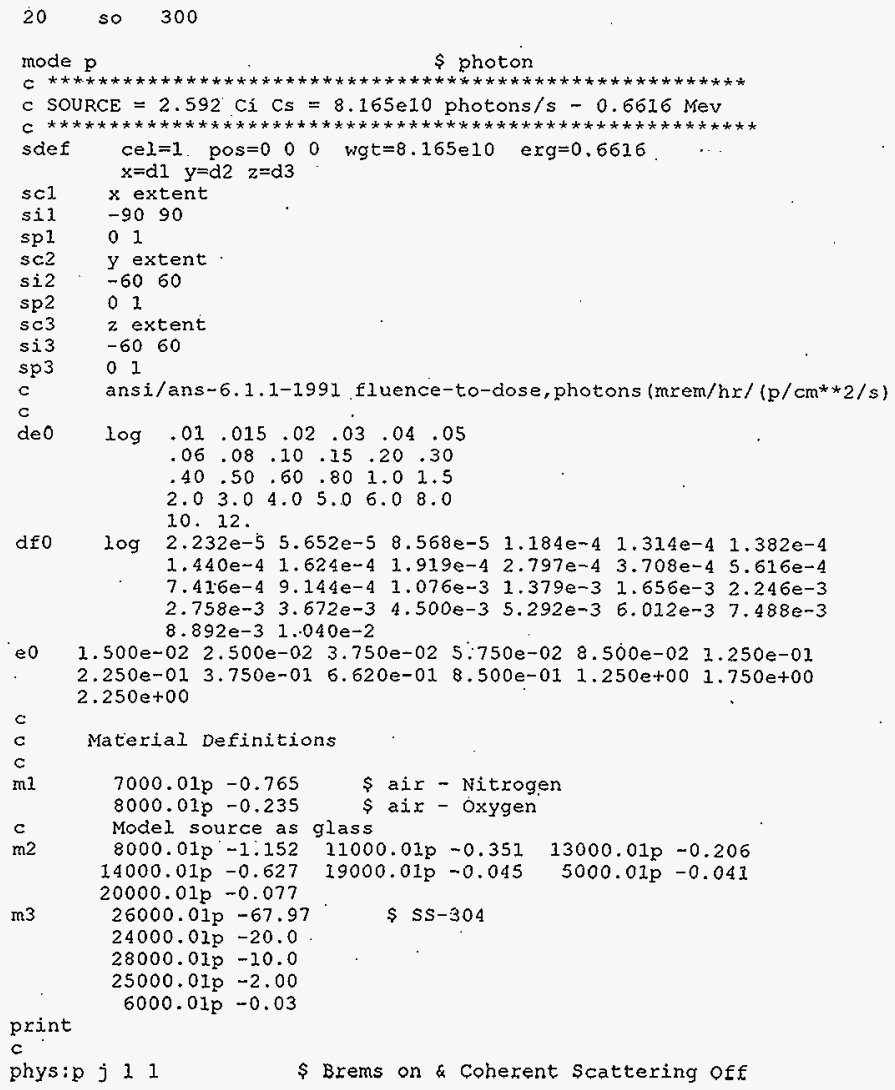


HNF-2110 Rev 0

\section{ENGINEERING ANALYSIS/DESIGN CALCULATION}
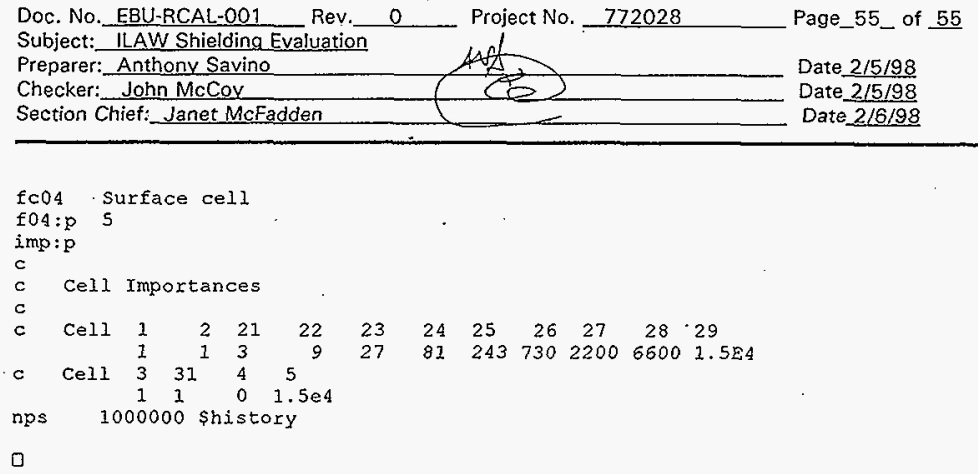
HNF-2110 Rev 0

This page intentionally left blank.

B-58 


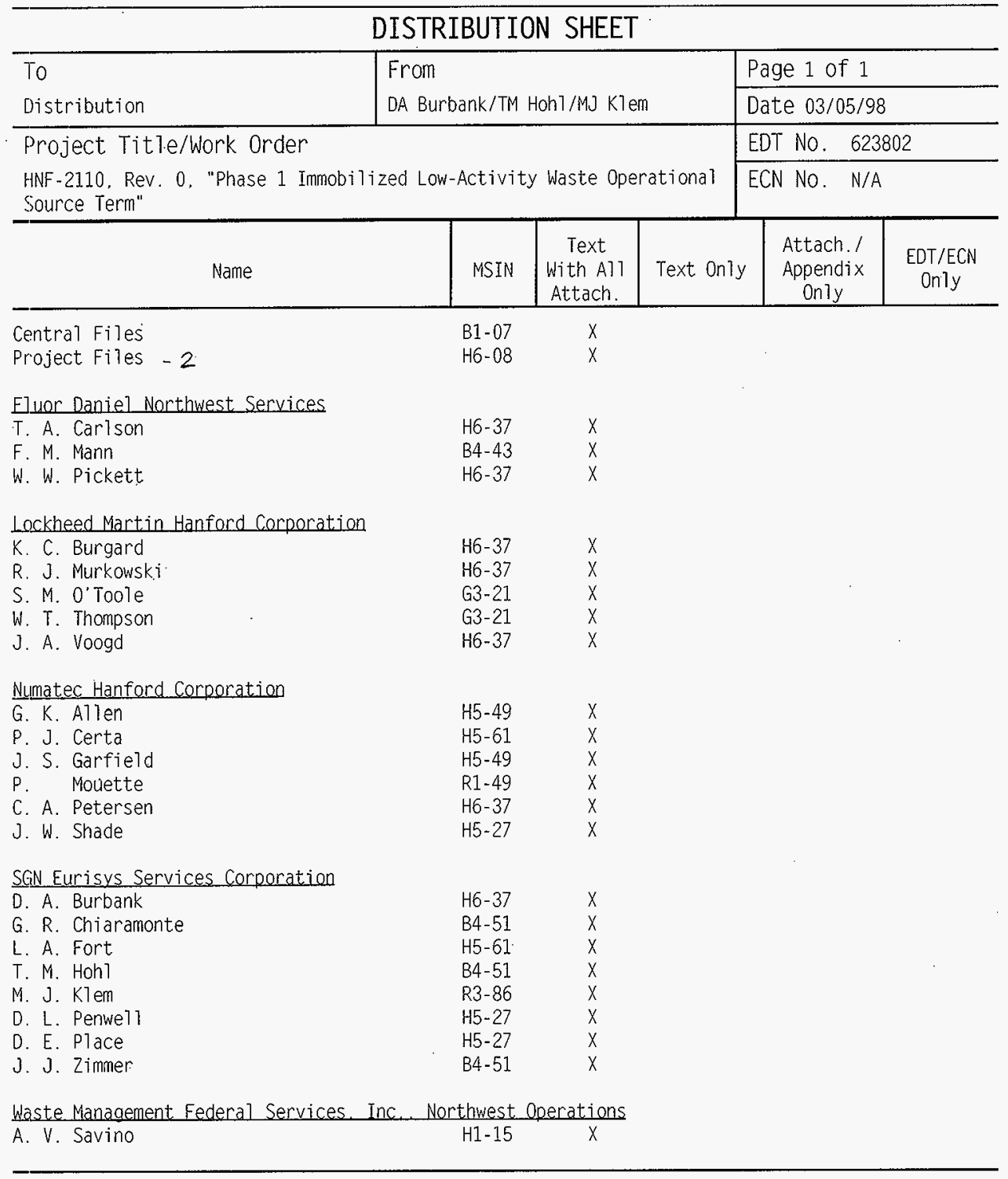

